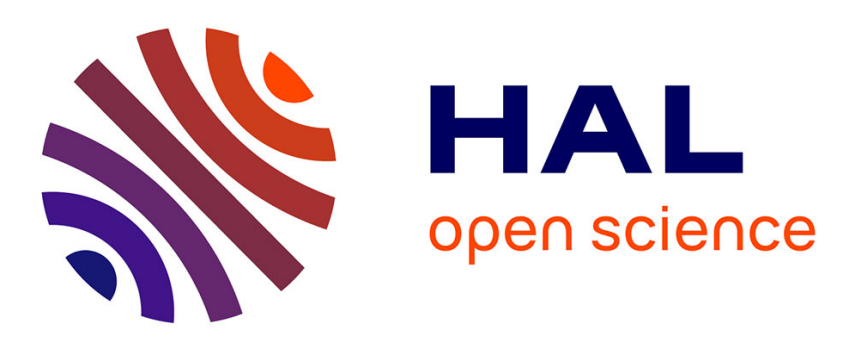

\title{
First partial cranium of Togocetus from Kpogamé (Togo) and the protocetid diversity in the Togolese phosphate basin
}

Koffi Evenyon Kassegne, Mickaël J Mourlam, Guillaume Guinot, Yawovi Zikpi Amoudji, Jérémy Martin, Kodjo Adika Togbe, Ampah Kodjo Johnson, Lionel Hautier

\section{To cite this version:}

Koffi Evenyon Kassegne, Mickaël J Mourlam, Guillaume Guinot, Yawovi Zikpi Amoudji, Jérémy Martin, et al.. First partial cranium of Togocetus from Kpogamé (Togo) and the protocetid diversity in the Togolese phosphate basin. Annales de Paléontologie, 2021, 107 (2), pp.102488. 10.1016/j.annpal.2021.102488 . hal-03435111

\section{HAL Id: hal-03435111 \\ https://hal.science/hal-03435111}

Submitted on 18 Nov 2021

HAL is a multi-disciplinary open access archive for the deposit and dissemination of scientific research documents, whether they are published or not. The documents may come from teaching and research institutions in France or abroad, or from public or private research centers.
L'archive ouverte pluridisciplinaire $\mathbf{H A L}$, est destinée au dépôt et à la diffusion de documents scientifiques de niveau recherche, publiés ou non, émanant des établissements d'enseignement et de recherche français ou étrangers, des laboratoires publics ou privés. 


\section{TITLE: First partial cranium of Togocetus from Kpogamé (Togo) and the protocetid diversity in the Togolese phosphate basin.}

\section{TITRE : Premier crâne partiel de Togocetus de Kpogamé (Togo) et la diversité des protocètes dans le bassin phosphaté togolais}
Koffi Evenyon KASSEGNE${ }^{1}$, Mickaël J. MOURLAM², Guillaume GUINOT ${ }^{2}$, Yawovi Zikpi AMOUDJI $^{1}$, Jeremy E. MARTIN ${ }^{3}$, Kodjo Adika TOGBE${ }^{1}$, Ampah Kodjo JOHNSON $^{1 *}$, and Lionel HAUTIER ${ }^{2 *}$

${ }^{1}$ Département de Géologie, Faculté des Sciences, Université de Lomé, B.P. 1515 Lomé, Togo ; christophe_johnson@yahoo.fr and kevenyon@gmail.com.

${ }^{2}$ Institut des Sciences de 1'Evolution de Montpellier, Université Montpellier, CNRS, IRD, Cc 064; place Eugène Bataillon, 34095 Montpellier Cedex 5, France; email: lionel.hautier@umontpellier.fr.

${ }^{3}$ Univ. Lyon, ENS de Lyon, Université Claude Bernard Lyon 1, CNRS, UMR 5276 Laboratoire de Géologie de Lyon : Terre, Planètes, Environnement, F-69342 46 Allée d'Italie, Lyon, France, jeremy.martin@ens-lyon.fr.

* Corresponding authors: lionel.hautier@ umontpellier.fr and christophe_johnson@yahoo.fr 


\begin{abstract}
:
Earliest cetaceans (whales) originated from the early Eocene of Indo-Pakistan, but the group dispersed through most of the oceans of the planet by the late middle to late Eocene. This late Eocene global distribution indicates that important dispersal events took place during the middle Eocene (Lutetian), a globally undersampled time interval that is well documented in the Togolese phosphate series. We report here the first discovery of a partial cetacean cranium from middle Eocene deposits of Togo (West Africa). A 3D model of the cranium and teeth was reconstructed in order to reveal hidden anatomical features. The dental and cranial characteristics of the Togolese specimen recall those of protocetid taxa described in Africa, Asia, and North America, but also display significant differences. In particular, we show that the new specimen shares a number of morphological features with the Togolese taxon Togocetus. Such a hypothesis is further supported by a cladistic analysis including 45 taxa and 167 morphological characters, which recovers the new specimen close to Togocetus as the first offshoot of protocetids. Phylogenetic analysis including all the protocetids remains of Kpogamé confirms the singular diversity of the Togolese phosphate basin, and enables to examine potential connections with faunas from contemporaneous localities in Africa.
\end{abstract}

Keywords: Protocetidae; Middle Eocene; Comparative anatomy; Phylogeny; Paleoenvironment. 


\section{Résumé :}

Il est admis que les premiers cétacés sont originaires de formations indo-pakistanaises datées du début Éocène. Cependant, leur dispersion à travers la plupart des océans n'aurait été effective qu'entre la moitié et la fin de l'Éocène. Leur répartition mondiale, à la fin de l'Éocène, indique toutefois que d'importants événements de dispersion ont eu lieu pendant l'Éocène moyen. Cet intervalle de temps, peu documenté à une échelle mondiale, est enregistré dans la série des phosphates du Togo (Afrique de l'Ouest). Nous décrivons ici le premier crâne partiel de protocète togolais provenant des gisements de phosphate datés de l'Éocène moyen. Une reconstruction 3D du crâne et des dents a été réalisée afin de révéler plusieurs caractéristiques anatomiques internes. Les caractères dentaires et crâniens du spécimen togolais rappellent ceux de taxons de protocètes décrits en Afrique, en Asie et en Amérique du Nord, mais présentent également des différences significatives. En particulier, nous montrons que le nouveau spécimen partage un certain nombre de caractéristiques morphologiques uniques avec Togocetus. Cette hypothèse est en outre soutenue par une analyse cladistique incluant 45 taxons et 167 caractères morphologiques. Il ressort de cette analyse que le clade incluant le nouveau spécimen et Togocetus représente un embranchement basal au sein des protocètes. L'analyse phylogénétique incluant l'ensemble des reste de protocètes de Kpogamé confirme la diversité singulière du bassin phosphaté togolais, et permet d'examiner des connexions potentielles entre cette faune de protocètes du Togo et les faunes d'autres bassins contemporains d'Afrique.

Mots clés : Protocetidae ; Eocène moyen ; Anatomie comparée ; Phylogénie ; Paléoenvironnement. 


\section{INTRODUCTION}

The Protocetidae is a diverse paraphyletic family of archaic whales that constitute a major step in the evolutionary transition from land mammals to fully aquatic cetaceans (Gingerich $e t$ al., 2009; Bianucci \& Gingerich, 2011). Protocetids were all quadrupedal swimmers but displayed diverse locomotor lifestyles from the amphibious basal forms to fully pelagic species (Buchholtz, 1998, 2007; Luo \& Gingerich, 1999; Gingerich, 2010; Gao \& Ni, 2015; Bebej \& Smith, 2017; Vautrin et al., 2020), and thanks to their inferred osmoregulatory capabilities (Clementz et al., 2006), were capable of crossing vast oceanic areas (Lambert et al., 2019). From their cradle in Pakistan, the group rapidly dispersed westward through the Tethys Seaway (Wang et al., 2002; Fordyce, 2018) to colonize most of the oceans of the planet in only a few million years from the early to the late Lutetian (Lambert et al., 2019). Although originating from Asia, the family name was coined based on early African discoveries (Stromer, 1908), following the description of Protocetus atavus from the middle Eocene Mokattam Formation in Egypt (Fraas, 1904). Africa undoubtedly played a pivotal role during early protocetid dispersal events, as evidenced by subsequent discoveries made in the Eocene Formations of Nigeria (Andrews, 1920), Egypt (Bianucci \& Gingerich, 2011; Gingerich et al., 2019), Morocco (Gingerich \& Zouhri, 2015), Senegal (Hautier et al., 2014; Vautrin et al., 2020), and Togo (Gingerich \& Cappetta, 2014). However, the African fossil record of the family remains scarce and patchily distributed on the continent, while recent discoveries in West Africa revealed an unexpected diversity among protocetid assemblages (Hautier et al. 2014; Gingerich \& Cappetta, 2014; Gingerich \& Zouhri, 2015; Vautrin et al. 2020).

The first Western African protocetid remains were discovered in Bartonian deposits of the Ameki Formation in southern Nigeria (40.4 to 37.2 Myr; Arua \& Rao, 1987; Arua, 1988, 1991; 
Odumodu \& Nfor, 2012; Onuigbo et al., 2020) and were attributed to Pappocetus lugardi (Andrews, 1920). In the 1980s, Michel Traverse was in charge for undertaking the geological survey in the Togolese phosphate quarry of Hahotoé-Kpogamé when he discovered a rich vertebrate fauna from middle Eocene deposits (Cappetta \& Traverse, 1988), including many fragmentary protocetid fossils. Gingerich \& Cappetta (2014) described most of these remains and named a new protocetid genus and species, Togocetus traversei, based on isolated teeth as well as incomplete cranial and postcranial elements. It has been suggested that To. traversei lived alongside two distinctly larger and smaller protocetid taxa, which could not be assigned to any previously recognized taxa due to the limited nature of the material (Gingerich \& Cappetta, 2014). Such a diversity of early cetacean taxa was later supported by Mourlam \& Orliac (2017, 2018) through a reassessment of isolated petrosal bones and tympanic bullae originally collected by Michel Traverse. Complete cranial material can prove essential to confidently delimitate extinct species, as tooth position and intraspecific dental variation might be challenging to ascertain based on isolated teeth only. Of the five protocetid genera described in Africa (i.e. Protocetus, Aegyptocetus, Pappocetus, Togocetus, and Aegicetus), only Protocetus (Fraas, 1904) and Aegyptocetus (Bianucci \& Gingerich, 2011) are represented by subcomplete cranial material. Recent paleontological fieldworks in southern Togo demonstrated the great potential for new discoveries in the phosphate series of this area. The specimen described here corresponds to a partial protocetid cranium unearthed from the quarry of Kpogamé and potentially constitutes the most complete cranial remain of the recently described Togocetus. Here, we seek to: (i) describe the morphology of the new Togolese specimen; (ii) clarify its phylogenetic position, (iii) and discuss its systematic significance. 


\section{GEOLOGICAL CONTEXT}

The Togolese phosphate deposits cover an area of $\sim 70 \mathrm{~km}^{2}$, extending from Aveta in the South West to Dagbati in the North West (Visse, 1957; Colonna-Cimera, 1961; Slansky, 1962; Johnson, 1987) (Fig. 1A). They are now exploited by the Société Nouvelle des Phosphates du Togo (SNPT) in two quarries at Kpogamé (SW) and Dagbati (NE).

Stratigraphically, the phosphate complex overlies a lower Eocene palygorskite-rich claystone (Johnson, 1987). The palygorskite-rich claystone constitutes the upper unit of the Tabligbo Group. The phosphate complex is made of three informal formations, from the base to the top (Slansky, 1962; Johnson, 1987) (Fig. 1B):

- The phosphatic marl formation (15 to $20 \mathrm{~m}$ thick), which was described as a phosphate biomicrite with a clay or marl matrix and a high abundance of benthic and planktonic foraminifera (Slansky, 1962; Monciardini et al., 1986; Johnson, 1987). This formation is intersected by limestone layers of various thicknesses, ranging from 5 to $10 \mathrm{~m}$, which contain a few foraminifera (Johnson et al., 2000).

- The phospharenite layer is $2 \mathrm{~m}$ to $8 \mathrm{~m}$ thick and consists of phosphate grains, pellets, coproliths, and elasmobranch tooth fragments (Slansky, 1962; Johnson, 1987; Johnson et al., 2000). The phospharenite layer is continuous laterally with calcareous phosphate in the South East of the basin. The calcareous phosphate consists of alternating white shellrich limestone and soft-beige phospharenite. An abundant elasmobranch fauna (Slansky, 1962; Cappetta \& Traverse, 1988) was discovered in the transition zone between the calcareous phosphate formation and phospharenite, in association with numerous fragments of the internal casts of gastropods, lamellibranchs, and nautilid fragments (Slansky, 1962; Johnson, 1987), as well as mammal remains (Gingerich \& Cappetta, 
2014). The base of these phospharenite and calcareous phosphate layers is made of claystone, marl, and limestone with an average thickness of $1.5 \mathrm{~m}$. The phospharenite and calcareous phosphate layers have been attributed to middle Eocene based on the elasmobranch fauna (Cappetta \& Traverse, 1988) and to middle Lutetian biozone P11 based on foraminifera (Da Costa et al., 2013).

- The phosphatic clay ( 0.5 to $10 \mathrm{~m}$ thick) consists of layers of green to brown claystone (oxidized) intersected with small lenticular layers of beige phospharenite alternating with continuous layers of phospharenites (Johnson, 1987).

Previous paleontological and sedimentological studies (Johnson, 1987; Cappetta \& Traverse, 1988; Johnson et al., 2000) were carried out in the north-eastern part of the Kpogamé quarry (Fig. 1). The specimen described here was discovered in 2016 in the southwest part of this quarry (N $06.28983^{\circ}$ and $\mathrm{E} 001.32169^{\circ}$ ), approximatively $6 \mathrm{~km}$ from the area surveyed by Johnson (1987) and Cappetta \& Traverse (1988), which yielded To. traversei (Gingerich \& Cappetta, 2014). The lithological succession varies slightly between the NE and SW parts of the quarry. In the southwest, the most basal facies consists of greenish stratified clay overlain by a thin layer of greyish clay. In the northeast part of the quarry (Johnson, 1987; Cappetta \& Traverse, 1988; Johnson et al., 2000), this clay is absent, and a bone bed occupies the same stratigraphic position (Johnson 1987; Cappetta \& Traverse, 1988; Johnson et al., 2000). On top of this clay layer, the main phosphate deposit is composed of alternating thick layers of soft brownish phospharenite $(50 \mathrm{~cm}$ to $300 \mathrm{~cm})$ and a thin layer of purplish compact oxidised phosphate $(10 \mathrm{~cm})$. This main phosphate layer (2.5 to $3 \mathrm{~m}$ ) includes at its base a yellowish compact phosphatic limestone with coprolites, shell fragments, and elasmobranch teeth, which yielded the specimen described here (Fig. 1). This phosphatic limestone is about $100 \mathrm{~cm}$ to $150 \mathrm{~cm}$ thick, and its thickness increases towards the southeast, whereas the thickness of the main phosphate layer decreases in the same 
direction. There is no unconformity between the carbonate and phosphate layers, which suggests a relatively progressive change from carbonate to phosphate sedimentation (Slansky, 1962; Johnson, 1987; Cappetta \& Traverse, 1988; Johnson et al., 2000).

\section{MATERIAL AND METHOD}

\section{Fossil specimen}

The specimen described here was prepared with pneumatic drills and consolidated with cyanoacrylate glue.

\section{D reconstruction of the cranium}

The cranium and upper tooth rows were imaged using high-resolution microtomography $(\mu \mathrm{CT})$ at the MRI platform of the Institut des Sciences de l'Evolution de Montpellier (ISE-M). Image segmentation of the cranium elements was performed on the $\mu \mathrm{CT}$ images with Avizo.Lite 2019.4 (Visualization Sciences Group) software. The 3D virtual restoration was performed with MorphoDig software (v. 1.5.3; Lebrun, 2018). The virtually restored 3D model is deposited in MorphoMuseum (Kassegne et al., 2021).

\section{Measurements}

The cranium and tooth rows were measured following the protocol of Bianucci \& Gingerich (2011) on 3D models with Avizo.Lite 2019.4 software (Vizualization Sciences Group). All measurements are given in Tables 1-2.

\section{Comparisons}


The cranium was compared with those of remingtocetids such as Dalanistes ahmedi (Gingerich et al., 1995a) and Remingtonocetus domandaensis (Gingerich et al., 2001b). It was also compared with African protocetids from Egypt, Protocetus atavus (Fraas, 1904; Kellogg, 1936), Aegyptocetus tarfa (Bianucci \& Gingerich, 2011), and with Asian protocetids from Pakistan, Rodhocetus kasrani (Gingerich et al. 1994), Maiacetus inuus (Gingerich et al., 2009), Takracetus simus (Gingerich et al., 1995b), Artiocetus clavis (Gingerich et al., 2001a), Gaviacetus razai (Gingerich et al., 1995a; Luo and Gingerich, 1999), Qaisracetus arifi (Gingerich et al., 2001b), Makaracetus bidens (Gingerich, 2005), and India, Kharodacetus sahnii (Bajpai \& Thewissen, 2014), Dhedacetus hyaeni (Bajpai \& Thewissen, 2014), Babiacetus indicus (Gingerich et al., 1995b). American protocetids were also used for comparisons: Georgiacetus vogtlensis (Hulbert et al., 1998), Carolinacetus gingerichi (Geisler et al., 2005), and Tupelocetus palmeri (Gibson et al., 2019).

Tooth rows were compared with those of remingtonocetid taxa like Re. harudiensis (Bajpai et al., 2011) and Re. domandaensis (Gingerich et al., 2001b) as well as protocetid taxa like Ma. inuus (Gingerich et al., 2009), Ro. kasrani (Gingerich, et al., 1994), Ar. clavis (Gingerich et al., 2001a), Pr. atavus (Fraas, 1904; Kellogg, 1936), Indocetus ramani (Gingerich et al., 1993), Q. arifi (Gingerich et al., 2001b), Ag. tarfa (Bianucci \& Gingerich, 2011), Dh. hyaeni (Bajpai \& Thewissen, 2014), K. sahnii (Bajpai \& Thewissen, 2014), To. traversei (Gingerich \& Cappetta, 2014), Ge. vogtlensis (Hulbert et al., 1998), B. indicus (Gingerich et al., 1995), Ca. gingerichi (Geisler et al., 2005), Tu. palmeri (Gibson et al., 2019), and Aegicetus gehennae (Gingerich et al., 2019).

\section{Phylogenetic analysis}


A matrix of 167 characters and 45 taxa has been assembled to assess the phylogenetic position of the new Togolese specimen. The core of this matrix is based on Geisler et al. (2005), and Gol'din \& Zvonok (2013) supplemented with one additional character from Thewissen \& Hussain (2000), one from Bianucci \& Gingerich (2011), 20 from Mourlam \& Orliac (2018), two from Gibson et al. (2019), two from Lambert et al. (2019) and 22 from Vautrin et al. (2020). Among them, 15 characters have been modified and/or split into new ones (see characters 2, 9, 10, 20, 30, 31, 45, 46, 53, 75, 87-92, 94, 116 and 124; see also Supplementary Text 1). In addition, we defined 19 new phylogenetic characters (see characters 149-167). All characters have equal weight and are parsimony-informative, and 35 of them are ordered. The taxonomic sample follows that of Mourlam \& Orliac (2018) to which we added the remingtonocetids Attockicetus (Thewissen \& Hussain, 2000) and Rayanistes (Bebej et al., 2015), along with eight protocetids: Takracetus (Gingerich et al., 1995a), Natchitochia (Uhen, 1998), Dhedacetus and Kharodacetus (Bajpai \& Thewissen, 2014), Tupelocetus (Gibson et al., 2019), Peregocetus (Lambert et al., 2019), Aegicetus (Gingerich et al., 2019) and cf. Carolinacetus sp. (SNTB 201101; Vautrin et al., 2020). Furthermore, due to several modifications in previously defined phylogenetic characters, we decided to reassess the tympanic bulla assignment of Togocetus by Mourlam \& Orliac (2018). Thus, Togocetus has been coded without any auditory region characters (referred below as Togocetus "earless"), and we considered its hypothesized tympanic bulla (i.e. morphotype $\beta$ ) as another operational taxonomic unit of its own. The matrix, in nexus format, along with the list of characters (Supplemental Text 2), are available in supplementary data. The parsimony analysis was performed with the software PAUP* 4.0a166 (Swofford, 2002), via the online platform CIPRES Science Gateway (Miller et al., 2010) through a Branch Swapping heuristic search using the Tree Bisection Reconnection method (TBR; Swofford \& Olsen, 1990; see also Darlu \& Tassy, 1993:85; Goëffon et al., 2010) with 1,000 replications, 
random taxa addition, 100 trees held by replication and Accelerated Transformation optimization (ACCTRAN; Farris, 1970; Swofford, 1985, 2002; see also Darlu \& Tassy, 1993:88). Branch support has been quantified with Bremer support values (Bremer, 1994). Finally, character states are indicated here in the form: Character ${ }^{\text {state }}$.

In order to simplify comparisons between the new Togolese specimen, Togocetus and other taxa, we here introduce two indexes: the shared index (Sha) and the similarity index (Sim). The shared index (in \%) is the number of common characters between two taxa relative to the total number of characters in one of them. Here, unless otherwise specified, we consider this index for the new Togolese specimen with a total number of 40 characters. The similarity index (in \%) corresponds to the number of shared character states relative to the total number of comparable characters between two taxa. The dataset compiling these indexes is available in supplementary data (Supplemental Table 1). For more accuracy, we considered the similarity index only if the shared index is at least at a threshold of $40 \%$, which corresponds to the shared index between the new Togolese specimen and Togocetus.

Abbreviations: ULDG KPO, Department of geology of the University of Lomé, Togo, KpogaméHahotoé collection.

\section{SYSTEMATIC PALAEONTOLOGY}

Class MAMMALIA Linnaeus, 1758

Order ARTIODACTYLA Owen, 1848

Suborder CETACEA Brisson, 1762 
Infraorder ARCHAEOCETI Flower, 1883

Family PROTOCETIDAE Stromer, 1908

Genus Togocetus Gingerich \& Cappetta, 2014

Togocetus cf. traversei Gingerich \& Cappetta, 2014

Figures 2-6

Material: The specimen consists of a partial cranium prepared out of a calcareous phosphate matrix. The specimen is on loan at the Montpellier University for preparation and study, and will be stored in the collection of Geology Department of the University of Lomé, Togo. Official specimen number is 'ULDG KPO1', shorten here to KPO1.

Distribution: Phosphate complex of Hahotoé-Kpogamé, mid-Lutetian, middle Eocene. The specimen was found in the transition zone between the soft and calcareous phosphate deposits (Fig. 1).

Locality : Kpogamé, phosphate quarry $\left(\mathrm{N} 06.28983^{\circ}\right.$ and E $\left.001.32169^{\circ}\right)$ of the Société Nouvelle des Phosphates du Togo (SNPT).

\section{Description:}

Cranium - The partial cranium lacks the anterior part of the rostrum, the cranial roof, and most of the basicranium apart from the left zygomatic process of the squamosal. The maxilla, nasal, palatine, pterygoid, alisphenoid, and squamosal bones are preserved, as well as two incomplete dental rows described hereafter. As reconstructed, the remaining part of the skull approximately measures $37.6 \mathrm{~cm}$ from the anterior border of the canine to the postglenoid process of the 
squamosal, and $25.9 \mathrm{~cm}$ from the anterior border of the canine to the posterior end of the palate. Based on estimations, the length between the canine and palatine end appears shorter in KPO1 than in Artiocetus clavis (Gingerich et al., 2001a), Gaviacetus razai (Gingerich et al., 1995) Makaracetus bidens (Gingerich, 2005), Kharodacetus sahnii (Bajpai \& Thewissen, 2014), Aegyptocetus tarfa (Bianucci \& Gingerich, 2011), Georgiacetus vogtlensis (Hulbert et al., 1998), and longer than in Maiacetus inuus (Gingerich et al., 2009) and Qaisracetus arifi (Gingerich et al., 2001b). The preserved part of the snout is elongated and narrow (Figs. 2, 3) like in most protocetid genera.

Maxilla - The left maxilla is better preserved than the right one, which is mostly broken (Figs. 23). The premaxillae are absent, and the suture between the premaxilla and maxilla cannot be observed, the snout being broken just anteriorly to the left canine. The medial contact surface between the left maxilla and the nasals is exposed, the latter being ventrally deflected (Fig. 2). The left infraorbital foramen is small $(\mathrm{h}=15.4 \mathrm{~mm}, \mathrm{w}=7.3 \mathrm{~mm})$, oval in shape, and located vertically above the P3. This position differs from that observed in Ma. inuus (Gingerich et al., 2009), Ro. kasrani (Gingerich et al., 1994), Ar. clavis (Gingerich et al., 2001a), Q. arifi (Gingerich et al., 2001b), Ag. tarfa (Bianucci \& Gingerich, 2011), Dh. hyaeni (Bajpai \& Thewissen, 2014) in which the infraorbital foramen is located more anteriorly, above the diastema separating the $\mathrm{P}^{2}$ and $\mathrm{P}^{3}$. The lateral surface of the left maxilla is slightly concave anterior to the infraorbital foramen (Fig. 5). The palatal surface of the maxillae is deformed and fractured (Fig. 3) so that no palatal foramen could be identified with certainty. The suture between both left and right maxillae is visible towards the midline where the two bones meet to form the anterior part of the palate, which is slightly concave (Fig. 3). Diastemata are present between $\mathrm{C}$ and $\mathrm{P}^{1}(15.7 \mathrm{~mm})$, between $\mathrm{P}^{1}$ and $\mathrm{P}^{2}(15.6 \mathrm{~mm})$, and between $\mathrm{P}^{2}$ and $\mathrm{P}^{3}(14 \mathrm{~mm})$. The 
presence of a diastema between teeth from $\mathrm{C}$ to $\mathrm{P}^{3}$ constitutes a distinctive characteristic observed in most protocetid taxa. In KPO1, the length of the diastema decreases from $\mathrm{C}^{3}$ to $\mathrm{P}^{3}$, $\left(15.7 \mathrm{~mm}, \mathrm{C}-\mathrm{P}^{1} ; 15.6 \mathrm{~mm}, \mathrm{P}^{1}-\mathrm{P}^{2} ; 14 \mathrm{~mm}, \mathrm{P}^{2}-\mathrm{P}^{3}\right)$. A similar decrease in length is observed in $R o$. kasrani (Gingerich et al., 1994) but with different values (18.5mm, 11.3mm and 3.3mm). In contrast, the diastema length increases from $\mathrm{C}$ to $\mathrm{P}^{3}$ in $A g . \operatorname{tarfa}(24.2 \mathrm{~mm}, 25 \mathrm{~mm}, 26 \mathrm{~mm}$; Bianucci \& Gingerich, 2011). Concave embrasure pits are visible between the right $\mathrm{P}^{2}$ and $\mathrm{P}^{3}$ and on the mesio-buccal side of the $\mathrm{P}^{4}, \mathrm{M}^{1-3}$ (Fig. 3); these concavities receive the tip of the corresponding lower teeth in occlusion. Such pits are present in some species, but their positions vary substantially between taxa. As for Ag. tarfa (Bianucci \& Gingerich, 2011), pits are present from $\mathrm{P}^{2}$ to $\mathrm{M}^{2}$ in KPO1, the one between $\mathrm{M}^{1}$ and $\mathrm{M}^{2}$ being very large. However, the former also displays embrasure pits between $\mathrm{C} / \mathrm{P}^{1}$ and $\mathrm{P}^{1} / \mathrm{P}^{2}$ and lack the one between $\mathrm{M}^{2} / \mathrm{M}^{3}$. Georgiacetus vogtlensis (Hulbert et al., 1998) displays embrasure pits medial to the $\mathrm{P}^{4}, \mathrm{M}^{1}, \mathrm{M}^{2}$, and $\mathrm{M}^{3}$. Embrasure pits are found between $\mathrm{P}^{3}-\mathrm{P}^{4}-\mathrm{M}^{1}-\mathrm{M}^{2}$ in $K$. sahnii (Bajpai \& Thewissen, 2014), between $\mathrm{P}^{3}-\mathrm{P}^{4}$ and $\mathrm{M}^{1}-\mathrm{M}^{2}$ in Ma. inuus (Gingerich et al., 2009) and Ro. kasrani (Gingerich et al., 1994); they are present lingual to the anterior side of $\mathrm{P}^{4}, \mathrm{M}^{1}$, and $\mathrm{M}^{2}$ in $Q$. arifi (Gingerich et al., 2001b). In Aegicetus gehennae (Gingerich et al., 2019), the embrasure pits are only visible between $\mathrm{P}^{3}-\mathrm{P}^{4}$. Indocetus ramani (Bajpai \& Thewissen, 2014) displays embrasure pits between $\mathrm{P}^{3}$ and $\mathrm{P}^{4}$, and posterior to the $\mathrm{M}^{1}$.

Nasal - The nasal is a thick and paired bone, which is largely broken both anteriorly and posteriorly and deflected ventrally (Fig. 2). The preserved part of the nasal extends from the level of the anterior root of the $\mathrm{P}^{2}$ to the anterior root of the $\mathrm{M}^{1}$. The contacts with the premaxillae and the frontals are not preserved. Their width is almost constant throughout their length but slightly 
widens posteriorly at the level of the $\mathrm{P}^{4}$. The crenulated contact surface of the right nasal is visible in lateral and dorsal views (Fig. 2). The suture between the two nasals is not fused. In $\mu \mathrm{CT}$ images, the ventral surface of the nasals is strongly concave.

Vomer - The morphology of the vomer could be assessed based on $\mu \mathrm{CT}$ images (Kassegne et al., 2021). The vomer is a long and intricate slingshot-shaped structure. It attaches dorsally to the palatal process of the maxillary via a fine basal branch that bifurcates dorsally into two parallel branches, which never join along their entire length.

Palatine - The palatine is wider on the maxillary side and tapered on the pterygoid side. It does not bear a foramen. Anteriorly, the suture between the maxillae and the palatine is hardly identifiable visually but could be followed with the $\mu \mathrm{CT}$ data. It forms a narrow band, which is enclosed between the two maxillae. Its posterior suture with the pterygoids is not identifiable. The palatine of KPO1 forms a narrow band enclosed between the two dental rows starting at $\mathrm{P}^{4}$ and widening at $\mathrm{M}^{3}$ (Fig. 3), which clearly departs from the shape of the palatine observed in other taxa. In Ga. razai (Gingerich et al., 1995), Mk. bidens (Gingerich, 2005), Ag. tarfa (Bianucci \& Gingerich, 2011), and Ge. vogtlensis (Hulbert et al. 1998), the palatines interlock between the two dental rows forming a flat, triangular wedge. The anteriormost tip of the palatine is located at the $\mathrm{P}^{4}$ level in KPO1, Protocetus atavus (Fraas, 1904), Ga. razai (Gingerich et al., 1995), and Ag. tarfa (Bianucci \& Gingerich, 2011); it ends medial to $\mathrm{P}^{2}$ in K. sahnii (Bajpai \& Thewissen, 2014) and medial to $\mathrm{M}^{1}$ in Mk. bidens (Gingerich, 2005).

Alisphenoid - The alisphenoid usually articulates with the pterygoid anteriorly and the squamosal posteriorly. However, no suture was visible to the naked eye or with $\mu \mathrm{CT}$ data. The foramen 
ovale is identifiable (Fig. 3), so part of the alisphenoid is likely present between the pterygoid and the squamosal. The long axis of the foramen ovale is $10.1 \mathrm{~mm}$ long and its short axis is $8.6 \mathrm{~mm}$.

Squamosal - Only the left squamosal is preserved (Figs. 2-3). The supramastoid crest is visible in dorsal view (Fig. 2). In ventral view (Fig. 4A), the zygomatic process of the squamosal is well preserved and slightly broken at the level of the supposed contact with the jugal. The glenoid fossa is rather flat and broad mediolaterally. This fossa is bordered posteriorly by the postglenoid process, which is blunt. This process, $30 \mathrm{~mm}$ high, arises ventrally and overhangs posteriorly the external auditory meatus almost perpendicularly to the zygomatic process of the squamosal. Thus, the postglenoid process largely contributes to the anterior margin of the ear canal. As for the posterior margin of the external auditory meatus, it is called the postmeatal process of the squamosal (Luo \& Gingerich, 1999). Interestingly, the posterior surface of the postmeatal process is deeply marked by a $5 \mathrm{~mm}$ wide sulcus oriented dorsoventrsally. To our knowledge, this sulcus is unknown in protocetids. The petrotympanic complex is missing, and it is impossible to assess whether this "postmeatal sulcus" could be linked to the stylomastoid foramen or possibly to the position of the tympanohyal (Luo \& Gingerich, 1999).

The external auditory meatus is about $8 \mathrm{~mm}$ wide (at its narrowest part) and $22 \mathrm{~mm}$ long. This pathway for airborne sound transmission is oriented following the posterolateralanteromedial axis and leads anteromedially to a depression in the shape of an isosceles triangle. This triangular fossa corresponds to the contact site for the sigmoid process of the ectotympanic (Luo \& Gingerich, 1999). A small ovoid foramen is visible anterior to the lateral apex of this triangle, on the medial flank of the postglenoid process. Its long axis is parallel to the external auditory meatus and is $3.2 \mathrm{~mm}$ long while its short axis is $1.1 \mathrm{~mm}$. The location of this foramen 
matches that of the postglenoid foramen. Interestingly, at the anteromedial tip of the triangular fossa, the vascular groove (sensu Luo \& Gingerich, 1999) dives dorsoventrally. This vascular groove contributes to the lateral border of a foramen passing at the interface between the squamosal and the petrosal (see anteroexternal sulcus of the petrosal in Luo \& Gingerich, 1999; Martínez-Cáceres et al., 2017; Mead \& Fordyce, 2009; Mourlam \& Orliac, 2018). Based on previous studies (int. al. Martínez-Cáceres et al., 2017, Geisler \& Luo, 1998), this vascular foramen should correspond to the postglenoid foramen (see also Gibson et al., 2019; Mourlam \& Orliac, 2018). However, because KPO1 exhibits a distinct postglenoid foramen posterolaterally (see also Supplemental Fig. 1), this vascular foramen cannot be linked to the passage of the capsuloparietal emissary vein (see also Mead \& Fordyce, 2009). Thus, we consider here that this vascular foramen corresponds to the ramus superior of the stapedial artery (e.g. Wible, 1993; Luo \& Gingerich, 1999; de Muizon et al. 2015). Medial to the glenoid fossa and anterior to the contact site on the squamosal for the sigmoid process of the ectotympanic, a wide and shallow bony channel runs anteroposteriorly. This channel constitutes a pathway between the medial side of the dentary and the lateral side of the tympanic bulla. We hypothesize that this channel could have hosted in life some fatty tissue used for underwater sound transmission (e.g. Nummela et al. 2007; Nummela \& Yamato, 2018). An elongated entoglenoid process (about $28 \mathrm{~mm}$ long from its most posteromedial point to its most anterolateral one) is present anteromedial to the triangular depression. Contrary to most protocetids for which this structure has been described, its entoglenoid process is not falciform but hat-shaped (subrectangular, Fig. 4C). This process supposedly contacts the thin bony lamina that extends anteriorly from the tubarius process of the ectotympanic (Luo \& Gingerich, 1999; Mourlam \& Orliac, 2018). The posterior third of the medial side of the entoglenoid process is overhanging the empty space normally filled by the petrosal. A small bony hook emerges anteromedial to that part of the entoglenoid process. This 
bony structure delimits the anterior part of the fossa for the tensor tympani muscle located on the petrosal. Anterior to that hook, a broad sulcus runs anteromedially and follows the anterior twothirds of the medial side of the entoglenoid process. This sulcus corresponds to the lateral margin of the Eustachian tube. The anterior third of the medial side of the entoglenoid process consists of a thin bony wall. This wall contributes to the ventral margin of the foramen ovale that deeply excavates the anterolateral part of the entoglenoid process. Based on the preservation of the specimen, it is not possible to identify the limit between the squamosal and the alisphenoid. Therefore, the precise location of the foramen ovale cannot be assessed in relation to these two bony units.

In medial view (Fig. 4B), the postmeatal process is riddled with lines that converge anteromedially towards the location of the petrotympanic complex. This structure corresponds to the sutural surface for the posterior processes of the petrosal and the ectotympanic (e.g. Gibson et al., 2019). Anteriorly, the smooth surface of the squamosal presents two bowl-shaped recesses: a broad ventral one and a smaller dorsal one. The broad recess hosts part of the petrosal in life but does not correspond to the counter-impression of this bone (Gibson et al., 2019). The smaller recess is punctured by a large foramen (about $4 \mathrm{~mm}$ wide). This foramen, probably broken ventrally, corresponds to the passage of the capsuloparietal emissary vein that exits the skull through the postglenoid foramen ( e.g. Wible, 1993; Geisler \& Luo, 1998; de Muizon et al., 2015). In addition, dorsoposterior to the smaller recess and dorsal to the postmeatal process, there is a deep and broad sulcus (about $4.3 \mathrm{~mm}$ wide) that pierces the external surface of the squamosal. This sulcus likely corresponds to a broken squamosal emissary foramen (Thewissen \& Bajpai, 2009) and therefore, could be the gateway into the skull for the vena diploëtica magna, just before it merges with the capsuloparietal emissary vein (Wible, 1993; de Muizon et al., 
2015). Interestingly, the squamosal emissary foramen is unknown within protocetids and is, at the archaeocete scale, only known for the remingtonocetid Kutchicetus (Thewissen \& Bajpai, 2009). Anterior to the two recesses, the vascular groove runs dorsoventrally and pierces the squamosal dorsolaterally. The dorsal aperture of this foramen was likely linked to an early diverging branch of the temporalis ramus. Anterior to the vascular foramen, a broad and shallow groove is visible and corresponds to the contact surface with the anterior process of the tegmen tympani of the petrosal.

Upper dentition - The cranium is lacking some teeth, especially on the right side where only the last three premolars and the first two molars are present (Fig. 2). The left dental row is more complete with eight teeth: one canine $(\mathrm{C})$, four premolars $\left(\mathrm{P}^{1-4}\right)$ and three molars $\left(\mathrm{M}^{1-3}\right)$. Most of the upper teeth are moderately worn, but some are largely broken, notably the $\mathrm{P}^{1}$ and molars. The crown ornamentation varies among KPO1 teeth. Some teeth have a smooth crown $\left(\mathrm{M}^{2}\right)$ and others $\left(\mathrm{P}^{3}\right.$ et $\left.\mathrm{P}^{4}\right)$ display a slightly crenulated enamel surface like Ag. Tarfa, To. traversei, Ge. vogtlensis, Tu. palmeri, and Ae. gehennae.

\section{Canine}

Only the left $\mathrm{C}$ is preserved. It is large compared to other teeth and curved backwards like in most protocetids but smaller than that of Pr. atavus (Fraas, 1904; Kellogg, 1936; Hulbert et al., 1998), Ag. tarfa (Bianucci \& Gingerich, 2011), To. traversei (Gingerich \& Cappetta, 2014), Ge. vogtlensis (Hulbert et al., 1998), and Ae. gehennae (Gingerich et al., 2019) (Table 12). The apex and the distal side of the crown are worn, with extensive exposure of the dentine. The crown is labio-lingually compressed with a faint mesial carina, like in Ag. tarfa (Bianucci \& 
Gingerich, 2011) and Ca. gingerichi (ChM PV 5401; Geisler et al., 2005), but unlike in Ma. inuus, where it is more conical (Gingerich et al., 2009). The canine of KPO1 is mainly singlerooted, as in all protocetids. Its orientation resembles that of To. traversei (KPG-M 3; Gingerich \& Cappetta, 2014). The apex of the root is bifurcated (Fig. 5 C-D), a situation only observed in Ge. vogtlensis (GSM 350; Hulbert et al., 1998) and possibly in K. sahnii (Bajpai \& Thewissen, 2014). The main root is large and curved backwards.

\section{Premolars}

The $\mathrm{P}^{1}$ of KPO1 is single-rooted. Its crown is poorly preserved, lacking its enamel cap (Fig. 3). It is, however, distinctly smaller than all other premolars (Figs 3-5), and is shorter than in Pr. atavus (Fraas, 1904; Kellogg, 1936; Hulbert et al., 1998), K. sahnii (Bajpai \& Thewissen, 2014), Ag. tarfa (Bianucci \& Gingerich, 2011), To. traversei (Gingerich \& Cappetta, 2014), Ge. vogtlensis (Hulbert et al., 1998), Ae. gehennae (Gingerich et al., 2019), and longer than in Ma. inuus (Gingerich et al., 2009). It is narrower than that of Ma. inuus (Gingerich et al., 2009), Pr. atavus (Fraas, 1904; Kellogg, 1936; Hulbert et al., 1998), K. sahnii (Bajpai \& Thewissen, 2014), Dh. hyaeni (Bajpai \& Thewissen, 2014), Ag. tarfa (Bianucci \& Gingerich, 2011), To. traversei (Gingerich \& Cappetta, 2014), Ge. vogtlensis (Hulbert et al., 1998), and Ae. gehennae (Gingerich et al., 2019) (Table 1-2). $\mathrm{P}^{1}$ has a single root like in Ma. inuus (Gingerich et al., 2009), I. ramani (Gingerich et al., 1993), Q. arifi (Gingerich et al., 2001b), To. traversei (Gingerich \& Cappetta, 2014), and probably Mk. bidens (Gingerich, 2005), but unlike Pr. atavus (Uhen, 1999), Dh. hyaeni (Bajpai \& Thewissen, 2014), K. sahnii (Bajpai \& Thewissen, 2014), Ge vogtlensis (Hulbert et al., 1998), Ae. gehennae (Gingerich et al., 2019), for which the $\mathrm{P}^{1}$ is double-rooted. The posterior side of the root is almost dorsoventrally oriented (Fig. 5). 
The $\mathrm{P}^{2}$ crown of KPO1 is monocuspidate and asymmetrical, its distal part being more developed (Table 1). It is smaller than that of Pr. atavus (Fraas, 1904; Kellogg, 1936; Hulbert et al., 1998), K. sahnii (Bajpai \& Thewissen, 2014), Ag. tarfa (Bianucci \& Gingerich, 2011), Dh. hyaeni (Bajpai \& Thewissen, 2014), To. traversei (Gingerich \& Cappetta, 2014), Ge. vogtlensis (Hulbert et al., 1998), Tu. palmeri (Gibson et al., 2019), but similar in size to that of Ma. inuus (Gingerich et al., 2009) (Table 1-2). Wear surface is visible at the apex of the crown. $\mathrm{P}^{2}$ displays a labio-lingually compressed crown with a sharp mesial carina joining a prominent cingulum, which is present on both labial and lingual surfaces. The crown differs from that of the $\mathrm{P}^{2}$ of $\operatorname{Pr}$. atavus (Fraas, 1904; Kellogg, 1936), in which the metacone is quite distinct from the paracone, and differs from Dh. hyaeni (Bajpai \& Thewissen, 2014), which has a protocone lobe. Unlike $\mathrm{P}^{1}$, $\mathrm{P}^{2}$ has two divergent anteroposterior roots like Ma. inuus (Gingerich et al., 2009), Ga. razai (Gingerich et al., 1995a), K. sahnii (Bajpai \& Thewissen, 2014), I. ramani (Gingerich et al., 1993), Q. arifi (Gingerich et al., 2001b), Mk. bidens (Gingerich, 2005), Ag. tarfa (Bianucci \& Gingerich, 2011), Dh. hyaeni (Bajpai \& Thewissen, 2014), B. indicus (Gingerich et al., 1995b), Ge. vogtlensis (Hulbert et al., 1998), and Tu. palmeri (Gibson et al., 2019). The base of the roots is exposed outside the alveoli (Fig. 5A). The root apexes are curved curved, but this character has not been described in any other protocetid taxa but is rarely preserved or visible.

$\mathrm{P}^{3}$ is almost symmetrical, the apex of the crown (paracone) is equidistant from its mesial and distal margins in occlusal view (Fig. 5E). However, the distalmost corner of the crown is more dorsally oriented in labial view (Fig. 5C), with the apex being closer from the mesial margin. The left and right $\mathrm{P}^{3}$ of KPO1 are shorter than those of Ma. inuus (Gingerich et al., 2009), Pr. atavus (Hulbert et al., 1998), I. ramani (Gingerich et al., 1993), Ag. tarfa (Bianucci \& Gingerich, 2011), To. traversei (Gingerich \& Cappetta, 2014), Ge. vogtlensis (Hulbert et al., 
1998), and Ae. gehennae (Gingerich et al., 2019); they are similar in size to those of Dh. hyaeni (Bajpai \& Thewissen, 2014) and K. sahnii (Bajpai \& Thewissen, 2014). (Table 1-2). It is less worn than $\mathrm{P}^{2}$ and shows no dentine exposure, as well as mesial and distal carinae. There is no sign of a distinct metacone, which differs from the situation observed in Pr. atavus (Fraas, 1904; Kellogg 1936), B. indicus (Gingerich et al., 1995b), Ge. vogtlensis (Hulbert et al., 1998), and Ae. gehennae (Gingerich et al., 2019) where the metacone is present. A faint distolingual swelling is visible close to the enamel-dentine junction surface (Fig. 5E), which is reminiscent of the presence of an incipient protocone lobe similar to To. traversei (Gingerich \& Cappetta, 2014) and unlike $\mathrm{P}^{3}$ teeth of Ma. inuus (Gingerich et al., 2009), Q. arifi (Gingerich et al., 2001), K. sahnii (Bajpai \& Thewissen, 2014), Ag. tarfa (Bianucci \& Gingerich, 2011), Ae. gehennae (Gingerich et $a l ., 2019)$ which have a protocone lobe. In contrast, Dh. hyaeni (Bajpai \& Thewissen, 2014) display a large protocone. The $\mathrm{P}^{3}$ of KPO1 do not show accessory cusps like Ag. tarfa (Bianucci \& Gingerich, 2011) contrary to what is observed in Ge. vogtlensis (Hulbert et al., 1998). They are double-rooted like in Ma. inuus (Gingerich et al., 2009), I. ramani (Gingerich et al., 1993), Q. arifi (Gingerich et al., 2001b), Mk. bidens (Gingerich, 2005) and Ae. gehennae (Gingerich et al., 2019). It is triple rooted in Ro. kasrani(Gingerich et al., 1994), Ta. simus (Gingerich et al., 1995a), Ga. razai (Gingerich et al., 1995a; Luo \& Gingerich, 1999), K. sahnii (Bajpai \& Thewissen, 1998), B. indicus (Gingerich et al., 1995b), and Ge. vogtlensis (Hulbert et al., 1998). The roots are exposed laterally above the level of the alveoli but less than in the $\mathrm{P}^{2}$ (Fig. 5A).

As compared to the $\mathrm{P}^{3}$, the crown of $\mathrm{P}^{4}$ is mesiodistally shorter and more asymmetrical (Fig. 5). It is triangular in labial view (Fig. 5C) with a long and straight mesial carina and a shorter distal carina. It corresponds to the widest tooth buccolingually (Fig. 5E) and is shorter and narrower than the $\mathrm{P}^{4}$ of Pr. atavus (Fraas, 1904), I. ramani (Gingerich et al., 1993), Ag. tarfa 
(Bianucci \& Gingerich, 2011), K. sahnii (Bajpai \& Thewissen, 2014), To. traversei (Gingerich \& Cappetta, 2014), Ge. vogtlensis (Hulbert et al., 1998), Ae. gehennae (Gingerich et al., 2019) (Table 1-2). In contrast, the dimensions of the $\mathrm{P}^{4}$ of KPO1 are very similar to those of Ma. inuus (Gingerich et al., 2009) (Table 1-2). The $\mathrm{P}^{4}$ is mainly constituted by a strong paracone, which is associated with a minute metacone that only individualizes towards the apex of the crown. It differs from the $\mathrm{P}^{4}$ attributed to To. traverse $i$ which does not have a distinct metacone (Fig. 6F \& H: Gingerich \& Cappetta, 2014). However, $\mathrm{P}^{4}$ of To. traversei is crossed by groove indicating the presence of a nearly completely fused metacone. A small groove also isolates the metacone of KPO1 from the paracone on the lingual side, faint on the buccal side. Such a metacone is absent in Ag. tarfa (Bianucci \& Gingerich, 2011), but present and distinct from the paracone in $P r$. atavus (Fraas, 1904; Kellogg, 1936), Dh. hyaeni (Bajpai \& Thewissen, 2014), K. sahnii (Bajpai \& Thewissen, 2014), B. indicus (Gingerich et al., 1995b) , Ge. vogtlensis (Hulbert et al., 1998), and Ae gehennae (Gingerich et al., 2019). As for the $\mathrm{P}^{3}$, a distolingual swelling is present (Fig. 5D). It is here more developed but does not form a distinct protocone as observed in the molars. This swelling called the protocone lobe (e.g. Bajpai \& Thewissen, 1998) is, however, supported by its own root. $\mathrm{P}^{4}$ has three roots, one below the protocone lobe on the lingual side and the other two under the main crown on the buccal side (Fig. 5C-E). The trifurcated-root $\mathrm{P}^{4}$ of KPO1 is also observed in K. sahnii (Bajpai \& Thewissen, 1998) but differs from Ma. inuus (Gingerich et al., 2009), which has a two-rooted $\mathrm{P}^{4}$. A small cingulum (2mm high) surrounds the base of the crown.

\section{Molars}


$\mathrm{M}^{1-3}$ crowns are present but not fully preserved. On the left dental row, all molar crowns are visible, but the $\mathrm{M}^{3}$ crown is mostly broken and fractured. On the right dental row, the $\mathrm{M}^{3}$ is absent. The molar row is closely packed, leaving no diastema between the teeth. A cingulum is visible on the distolingual corner of the left $\mathrm{M}^{3}$ crown (Fig. 5D) and the lingual side of the right $\mathrm{M}^{2}$, the other molars are too broken to observe its presence. As for the premolars, the base of the roots is exposed laterally above the level of the alveoli (Fig. 5A).

The $\mathrm{M}^{1}$ crown is not entirely covered with enamel. The $\mathrm{M}^{1}$ shows an individualized lingual protocone, and distinct paracone and metacone (Figs 5-6). The left $\mathrm{M}^{1}$ of KPO1 is slightly shorter than the $\mathrm{M}^{1}$ of I. ramani (Gingerich et al., 1993), Ag. tarfa (Bianucci \& Gingerich, 2011), To. traversei (Gingerich \& Cappetta, 2014), K. sahnii (Bajpai \& Thewissen, 2014), Ge. vogtlensis (Hulbert et al., 1998), Ae. gehennae (Gingerich et al., 2019); it is slightly longer than those of Pr. atavus (Fraas, 1904), and Dh. hyaeni (Bajpai \& Thewissen, 2014) (Table 1-2). The $\mathrm{M}^{1}$ is a three-rooted tooth as those of Ro. kasrani(Gingerich et al., 1994), Ta. simus (Gingerich et al., 1995a), Q. arifi (Gingerich et al., 2001b), K. sahnii (Bajpai \& Thewissen, 1998) and Ge. vogtlensis (Hulbert et al., 1998). In occlusal view, the $\mathrm{M}^{1}$ of KPO1 is triangular as that of $A g$. tarfa (Bianucci \& Gingerich, 2011) and Ae. gehennae (Gingerich et al., 2019). The presence of protocone on the $\mathrm{M}^{1}$ is also observed in taxa such as $Q$. arifi (Gingerich et al., 2001b), Ag. tarfa (Bianucci \& Gingerich, 2011), Dh. hyaeni (Bajpai \& Thewissen, 2014), K. sahnii (Bajpai \& Thewissen, 2014), B. indicus (Gingerich et al., 1995a), Ge. vogtlensis (Hulbert et al., 1998), and Ae. gehennae (Gingerich et al., 2019), even if their size and shape vary across these taxa. The protocone and metacone of the $\mathrm{M}^{1}$ of KPO1 are otherwise too badly preserved and no other details can be observed to allow comparisons with other taxa. 
The left $\mathrm{M}^{2}$ displays a large paracone, a small metacone, and a large protocone. The $\mathrm{M}^{2}$ are smaller than those of Ag. tarfa (Bianucci \& Gingerich, 2011), Ae. gehennae (Gingerich et al., 2019) (Table 1-2); they are similar in size to the $\mathrm{M}^{2}$ of Ma. inuus (Gingerich et al., 2009) and Dh. hyaeni (Bajpai \& Thewissen, 2014) (Table 1-2). The $\mathrm{M}^{2}$ paracone is larger than that of the $\mathrm{M}^{1}$ of KPO1. The paracone and metacone are joined by a shallow groove extending from the cusps to the cingulum on the buccal side and by a narrow, shallow groove on the lingual side. The inclined lingual surface is longer than the labial surface. The crown has a more or less smooth enamel surface. They show confluent medial and posterolateral roots, which only separate closely to their apex. The $\mathrm{M}^{2}$ are then three-rooted like in To. traversei (Gingerich \& Cappetta, 2014), Q. arifi (Gingerich et al., 2001b), Ta. simus (Gingerich et al., 1995a), and Ge. vogtlensis (Hulbert et al., 1998). In occlusal view, the outline of the $\mathrm{M}^{2}$ of Ae. gehennae crown is rectangular (Gingerich $e t$ al., 2019), which contrasts from that of KPO1, Ag. tarfa (Bianucci \& Gingerich, 2011), To. traversei (Gingerich \& Cappetta, 2014), and Dh. hyaeni (Bajpai \& Thewissen, 2014) that all display a triangular M2 crown .

The $\mathrm{M}^{3}$ is not well preserved. The labial side is missing; the lingual side is fractured. Its crown cannot be precisely compared. The only observable feature is a massive swelling in the distolingual corner of the crown (Fig. 5D), which corresponds to a protocone that is less individualized than in $\mathrm{M}^{1}$ and $\mathrm{M}^{2}$. A similar situation is observed in $Q$. arifi (Gingerich et al., 2001b), Ae. gehennae (Gingerich et al., 2019), and to a lesser extent in Ag. tarfa that display a more modest lingual expansion of the crown into a small protocone lobe (Bianucci \& Gingerich, 2011) like B. indicus (Gingerich et al., 1995b). The protocone is nearly disappears on $\mathrm{M}^{3}$ in $M a$. inuus according Gingerich et al. (2009). Only two branches of $\mathrm{M}^{3}$ roots are preserved, but the initiation of a third root is visible on the lingual side of the most posterior root, so that the $\mathrm{M}^{3}$ of 
KPO1 was probably three-rooted like that of Ro. kasrani (Gingerich et al., 1994), Q. arifi (Gingerich et al., 2001b), and Ge. vogtlensis (Hulbert et al., 1998). The $\mathrm{M}^{3}$ of KPO1 differs from those of Ta. simus (Gingerich et al., 1995b) and probably I. ramani (Gingerich et al., 1993), which present two roots aligned mesiodistally.

\section{Phylogenetic position of KPO1}

In order to assess the phylogenetic position of KPO1, we tabulated a matrix of 167 characters coded for 45 taxa (see Material and methods and Supplemental Texts 1-2 for more details). The cladistics analysis, performed with PAUP*, retained 2,100 most parsimonious trees of a length (L) of 674 steps, with a low consistency index $(\mathrm{CI}=0.49$; Kluge \& Farris, 1969) and a low retention index $(\mathrm{RI}=0.68$; Farris, 1989). The topology of the strict consensus tree $(\mathrm{L}=$ 691; $\mathrm{CI}=0.47 ; \mathrm{RI}=0.67$ ) is illustrated in Figure 7 and the node supports are detailed in Table 3. The topological structure of the strict consensus tree is consistent with that of previous analyses (e.g. Geisler et al., 2005; Gol'din \& Zvonok, 2013) with the protocetid whales found as a large paraphyletic group at the base of the Pelagiceti clade (node P; see Uhen, 2008)

Interestingly, KPO1 is found here as the first offshoot of the protocetids and forms a clade with Togocetus traversei (coded here without the auditory region, see materials and methods), which was erected on the basis of specimens from the Hahotoé-Kpogamé area. This clade (node Pr1) is supported by nine synapomorphies, including two non-ambiguous ones: the presence of a doubled preparacrista (see Gingerich \& Cappetta, 2014; Fig. 6) on the $\mathrm{M}^{2}\left(165^{1} ; \mathrm{RI}=0.50\right)$, and the presence of the metacone on the $\mathrm{P}^{4}\left(161^{1} ; \mathrm{RI}=0.57\right)$. This latter character state is convergent with higher protocetids (node Pr7) such as Protocetus (Fraas, 1904: pl. I fig. 2) and Georgiacetus (Hulbert et al., 1998: Fig. 8). In addition, we performed a second phylogenetic analysis 
considering KPO1 and the previous elements of Togocetus (without any auditory region elements) as one single operational taxonomic unit representing their genus. As a result, the topology of the consensus tree is identical to that of the first phylogenetic analysis and Togocetus remains as the first offshoot of the protocetid (see Supplemental Fig. 5) and is here defined by seven non-ambiguous autapomorphies (see Discussion).

Considering the whole matrix, only $24 \%$ of the characters are documented for KPO1. Among them, at least $52.5 \%$ present a plesiomorphic state at the cetacean scale (node C), such as the narrowing of the palate posterior to $\mathrm{M}^{3}\left(12^{0} ; \mathrm{RI}=0.67\right)$, the presence of a large protocone on $\mathrm{M}^{2}\left(90^{0} ; \mathrm{RI}=0.58\right)$ and the posterior edge of the infraorbital foramen located above $\mathrm{P}^{3}\left(150^{3} ; \mathrm{RI}\right.$ $=0.56$ ). In comparison, on a similar set of characters (Sha $=90 \%$; i.e. four characters less), the remingtonocetid Remingtonocetus presents $44.44 \%$ of plesiomorphic states, the protocetids Protocetus and Georgiacetus exhibit respectively $41.67 \%$ and $30.56 \%$ of it, and the basilosaurid Dorudon displays only $25 \%$ of it. In addition, the pakicetid family (Sha $=87.5 \%$ ) presents $74.29 \%$ of plesiomorphic states. With this first overview, it appears that KPO1 displays a rather high number of plesiomorphic features. More precisely, apart from Togocetus $($ Sha $=40 \% ; \operatorname{Sim}=$ 93.75\%), KPO1 presents strong commonalities with some basal archaeocetes (see Supplemental Fig. 3 and Supplemental Table 1); the ambulocetid Ambulocetus $($ Sha $=47.50 \%$; Sim $=63.16 \%$ ), the basalmost remingtonocetid Attockicetus $(\mathrm{Sha}=42.50 \%$; $\mathrm{Sim}=64.71 \%$ ) and three of the most basal protocetids: Rodhocetus $($ Sha $=65 \%$; Sim $=69.23 \%)$, Artiocetus $($ Sha $=80 \%$; Sim $=$ $62.50 \%)$, and Qaisracetus $(\mathrm{Sha}=72.50 \%$; Sim $=62.07 \%)$. In addition, Togocetus has also great resemblance with three basal protocetids (Supplemental Table 1): Rodhocetus $($ Sha $=69.23 \%$; Sim $=70.37 \%)$, Peregocetus $($ Sha $=51.28 \% ;$ Sim $=70 \%)$, and Qaisracetus $($ Sha $=46.15 \% ;$ Sim $=72.22 \%)$. Finally, in average, KPO1 is more similar to the protocetids $(\mathrm{Sha}=70.83 \%$; $\operatorname{Sim}=$ 
$52.21 \%$ ) than it is to the remingtonocetids $(\mathrm{Sha}=60 \%$; Sim $=45.97 \%)$, and the same goes for Togocetus (protocetid Sha $=58.97 \% ;$ Sim $=56.56 \%$ vs. remingtonocetids Sha $=59.83 \% ;$ Sim $=$ $38.05 \%)$.

Thus, contra Mourlam \& Orliac (2018) the phylogenetic position of Togocetus without its hypothesized tympanic bulla (i.e. morphotype $\beta$ ), is way more basal than previously found However, its former hypothesized tympanic bulla is still positioned as the last offshoot of the protocetids (Mourlam \& Orliac, 2018, Vautrin et al., 2020: fig.8) and belongs here to a multifurcation with Aegicetus, Babiacetus and Takracetus (node Pr12). This multifurcation is probably due to a lack of knowledge about the tympanic bullae of Aegicetus (Gingerich et al. 2019) and Babiacetus (Gingerich et al., 1995b) and by the fact that Takracetus' bulla is unknown (Gingerich et al., 1995a). This multifurcation is supported by 24 synapomorphies, eight of which are non-ambiguous, including for instance the absence of the second tuberosity of the involucrum $\left(71^{0} ; \mathrm{RI}=0.80\right)$, more than 14 thoracic vertebrae $\left(104^{2} ; \mathrm{RI}=0.67\right)$, the absence of an embrasure pit between $\mathrm{P}^{4}$ and $\mathrm{M}^{1}\left(155^{0} ; \mathrm{RI}=0.54\right)$ and the absence of the metacone on $\mathrm{P}^{2}\left(159^{0} ; \mathrm{RI}=0.25\right)$.

The morphotype $\gamma$ - one of the unknown protocetid taxa from Kpogamé according to Mourlam \& Orliac, (2018) - is found here as the sister taxon of Protocetus (node Pr10). A single non-ambiguous synapomorphy supports that clade and involves the medial posterior prominence of their tympanic bullae, which is smaller than the lateral posterior prominence $\left(60^{2} ; \mathrm{RI}=0.40\right)$. It is also interesting to note that in spite of this phylogenetic proximity, both taxa exhibit striking differences such as the two non-ambiguous autapomorphies of the morphotype $\gamma$, which are: a sub-rectangular entoglenoid process $\left(46^{3} ; \mathrm{RI}=0.86\right.$; Fig. $\left.4 \mathrm{C}\right)$ and the presence of the fifth tuberosity of the involucrum $\left(74^{1} ; \mathrm{RI}=0.50\right)$. Furthermore, the couple 'Protocetus - morphotype $\gamma$ ' belongs to a larger clade (node Pr8) that includes two protocetid taxa from India: Dhedacetus 
and Kharodacetus (Bajpai \& Thewissen, 2014). This larger clade is supported by 12 synapomorphies, of which only two are non-ambiguous: a narrow rostrum breadth at $\mathrm{P}^{2}\left(149^{0}\right.$; RI $=0.50)$ and the metacone as large as the paracone on the $\mathrm{M}^{2}\left(163^{0} ; \mathrm{RI}=0.71\right)$. In addition, it is noteworthy that some of the ambiguous synapomorphies supporting that clade concern the auditory region, such as the presence of the medial sulcus on the tympanic bulla $\left(61^{1} ; \mathrm{RI}=1.00\right)$. Nevertheless, this character state is so far only known for Protocetus and the morphotype $\gamma$.

Another protocetid taxon from Kpogamé has been referred to ?Carolinacetus sp. by Mourlam \& Orliac (2018). This referral is still supported in the current analysis (see Discussion). Indeed, ?Carolinacetus sp. falls within a clade (node Pr5) including cf. Carolinacetus sp. from Senegal (SNTB 2011-01; Vautrin et al., 2020) and two protocetid taxa from the same American locality in South Carolina: Carolinacetus (Geisler et al., 2005) and Tupelocetus (Gibson et al., 2019). This clade, which is multifurcated, is supported by seven non-ambiguous synapomorphies out of a total of 14: a thin anteroventral side of the internal auditory meatus riddled with foramina $\left(43^{1} ; \mathrm{RI}=0.67\right)$, a deep transinvolucrum sulcus $\left(69^{2} ; \mathrm{RI}=0.67\right)$, the presence of the fourth $\left(73^{1}\right.$; $\mathrm{RI}=1.00)$ and the fifth $\left(74^{1} ; \mathrm{RI}=0.50\right)$ tuberosities of the involucrum, wide and dorsoventrally flatten thoracic vertebrae $\left(107^{1} ; \mathrm{RI}=0.17\right)$, a deep and round depression behind the prezygapophyses $\left(109^{0} ; \mathrm{RI}=0.33\right)$, and the presence of the supraneural shelf on the thoracic vertebrae $\left(111^{1} ; \mathrm{RI}=0.50\right.$; see Vautrin et al., 2020).

The phylogenetic position of the remingtonocetids has been assessed here for the first time with all six taxa referred to this family. The monophyly of Remingtonocetidae is supported (node R) and the phylogenetic position of Attockicetus as the first offshoot of this family is consistent with the previous analysis of Thewissen \& Hussain (2000). However, the Bremer support of that clade is weak (i.e. Bremer index of 1) and among the 17 synapomorphies defining 
this family, only two are non-ambiguous: a transversely convex palate $\left(6^{2} ; \mathrm{RI}=0.12\right)$ and small orbits $\left(20^{0} ; \mathrm{RI}=0.44\right)$.

In contrast, the monophyly of Pelagiceti (node P) is strongly supported with 39 synapomorphies of which 17 non-ambiguous, including the narrowing of the palate at the level of the $\mathrm{M}^{1}\left(12^{3} ; \mathrm{RI}=0.67\right)$, an enlarged pterygoid sinus that forms a deep anteroposterior trough which approaches the internal nares $\left(33^{3} ; \mathrm{RI}=0.95\right)$, a straight medial angle of the tympanic bulla $\left(57^{2} ; \mathrm{RI}=0.90\right)$, a sub-circular dome-shape involucrum $\left(66^{4} ; \mathrm{RI}=0.86\right)$, and the loss of the protocone on the $\mathrm{P}^{3}\left(87^{3} ; \mathrm{RI}=0.73\right), \mathrm{P}^{4}\left(88^{3} ; \mathrm{RI}=0.47\right)$ and $\mathrm{M}^{1}\left(89^{3} ; \mathrm{RI}=0.62\right)$.

Within Pelagiceti, it is interesting to note the particular phylogenetic position of Kekenodon (node B). The phylogenetic position of this enigmatic late Oligocene taxon represented by scarce remains (Hector, 1881; Hernández-cisneros \& Tsai, 2016), is still poorly resolved, and it is not clear whether it belongs to Basilosauridae (e.g. Kellogg, 1936) or Mysticeti (e.g. Fordyce, 1992). In the results presented here, Kekenodon is not found sister to early neocetes contra previous studies built on the same dataset (e.g. Gol'din \& Zvonok, 2013; Mourlam \& Orliac, 2018). It represents instead the first offshoot of the basilosaurids (following Kellogg, 1936 and Mitchell, 1989). Notwithstanding, the present study is not designed to address this peculiar question. Be that as it may, the monophyly of Basilosauridae is supported here, as in previous works (e.g. Luo \& Gingerich, 1999; Martínez-Cáceres et al., 2017; Vautrin et al., 2020). Considering Kekenodon as its first offshoot (node B), the basilosaurid monophyly is then supported by two non-ambiguous synapomorphies: an elongated skull $\left(1^{2} ; \mathrm{RI}=0.50\right)$ and the presence of large accessory cusps on posterior premolars and molars $\left(77^{2} ; \mathrm{RI}=0.86\right)$.

\section{DISCUSSION}




\section{Systematic attribution and phylogenetic position of KPO1}

KPO1 represents, so far, the most complete skull specimen of a protocetid found from the Eocene deposits of Togo. It mainly consists of two maxillaries with their subcomplete associated dentition, alongside with part of the alisphenoid, nasal, palatine, vomer, pterygoid, and squamosal. The dental and cranial characteristics of this Togolese specimen display significant differences with those of other protocetid taxa, especially the African Aegyptocetus tarfa, Aegicetus gehennae, and Protocetus atavus. KPO1 differs from Ag. tarfa in its overall smaller size, the position of the infraorbital foramen, differential diastemata length, and the presence of a metacone on $\mathrm{P}^{4}$. Compared to Ae gehennae, KPO1 shows smaller or shorter upper teeth, a singlerooted $\mathrm{P}^{1}$, the absence of metacone on $\mathrm{P}^{3}$, and the triangular rather than rectangular outline shape of the $\mathrm{M}^{2}$ in occlusal view. KPO1 also differs from Pr. atavus in showing smaller premolars and molars and an absence of metacone on $\mathrm{P}^{2}$ and $\mathrm{P}^{3}$.

Togocetus is a poorly known protocetid taxon described by Gingerich \& Cappetta (2014) based on several isolated dental, cranial, and postcranial elements. These remains were considered to belong to To. traversei mostly based on size and preservation similarities as well as rarity of duplication of skeletal elements, but a recent reassessment of the morphological diversity of tympanic bullae (Mourlam \& Orliac, 2018) cast doubt on some initial attributions. Such uncertainties are inherent to the fragmentary and isolated nature of the material used to describe the species, and only the discovery of additional and more complete specimens will enable to ascertain the validity of the proposed associations between craniodental and postcranial materials. Apart from four isolated tympanic bullae (Mourlam \& Orliac, 2018), only a few cranial remains of To. traversei have been described; they correspond to portions of the mid cranial pons, the frontal shield, and two squamosals (Gingerich \& Cappetta, 2014). Most of these parts are 
missing on the new Togolese specimen, except for the left zygomatic process of the squamosal, which precludes any detailed comparisons. The zygomatic processes included in the original material described by Gingerich and Cappetta (2014) are very fragmentary but appear somewhat more slender than the specimen KPO1. Here, comparisons between KPO1 and Togocetus are therefore mainly restricted to dental features. The cladistic analysis demonstrated the sister relationship between KPO1 and Togocetus, which is supported by two non-ambiguous synapomorphies: the presence of the metacone on the $\mathrm{P}^{4}\left(161^{1} ; \mathrm{RI}=0.57\right)$, and the presence of a doubled preparacrista on the $\mathrm{M}^{2}\left(165^{1} ; \mathrm{RI}=0.50\right)$. Among their 16 common characters coded in the phylogenetic analysis $(\mathrm{Sha}=40 \%)$, only one of them presents a variation of character state $(\operatorname{Sim}=93.75 \%)$ : the position of the metacone on the $\mathrm{P}^{4}(162 ; \mathrm{CI}=0.50 ; \mathrm{RI}=0.00$ [i.e. tree steps $=\max$ steps]) that is nearly fused with the paracone for KPO1 $\left(162^{2}\right)$ and almost completely fused (i.e. only presence of a sulcus) for Togocetus $\left(162^{3}\right)$. This series of characters indicates that KPO1 is likely a representative of the genus Togocetus. The holotype of To. traversei, UM-KPGM 1, consists of a mandibular fragment retaining its $\mathrm{M}_{3}$ and the generic diagnosis relies on three states of character (Gingerich \& Cappetta, 2014): a relatively small mandibular canal $\left(97^{1} \mathrm{RI}=\right.$ 0.57 ), a salient metaconid on the $\mathrm{M}_{1}$ (somehow equivalent to $84^{2}$ in our analysis, $\mathrm{RI}=0.60$ ), and a femoral head lacking the fovea capitis femoris $\left(148^{0} \mathrm{RI}=0.50\right)$. There is therefore, to date, no known upper dental or cranial diagnostic feature for Togocetus and the skull fragment KPO1 then sheds a new light on the poorly known cranial anatomy of this taxon. Based on this new material and following the results of the second phylogenetic analysis (see Supplemental Fig. 5), we showed that Togocetus is a protocetid whale characterized by a transversely concave palate $\left(6^{0}\right.$; $\mathrm{RI}=0.12)$, the presence of a metacone on $\mathrm{P}^{4}\left(161^{1} ; \mathrm{RI}=0.57\right)$ located apically and nearly completely fused with the paracone $\left(162^{(23)} ; \mathrm{RI}=0.00\right)$, a doubled preparacrista on $\mathrm{M}^{2}\left(165^{1}\right.$; RI $=0.00)$, a talonid longer than the trigonid on the $\mathrm{M}_{1}$ and $\mathrm{M}_{2}\left(84^{2} ; \mathrm{RI}=0.60\right)$, a variable position 
of the mandibular symphysis (either below $\mathrm{P}_{1}$ or below the diastema between $\mathrm{P}_{2}$ and $\mathrm{P}_{3} ; 95^{(02)}$; RI $=0.61$, and the transverse processes of the thoracic vertebrae orientated laterally and dorsally $\left(110^{1} ; \mathrm{RI}=0.90\right)$. Three other state of characters could define Togocetus ambiguously; a subrectangular shaped entoglenoid process $\left(46^{3} ; \mathrm{RI}=0.86\right)$, a medium size mandibular foramen $\left(97^{1}\right.$; $\mathrm{RI}=0.57)$ and a thick sternum with a rectangular manubrium $\left(113^{1} ; \mathrm{RI}=0.80\right)$.

However, KPO1 also shows some morphological differences with To. traversei (Fig. 6). The teeth of KPO1 have similar proportions to the ones attributed to the latter, but are slightly smaller (Fig. 6 and Table 1). The root branches of $\mathrm{P}^{1}$ KPG-M9 (Fig. 6: Gingerich \& Cappetta, 2014) is bifurcating and divided by a faint lingual groove, but it is still single-rooted, as it is clearly the case in KPG-M20. Such lingual division is not observed on KPO1, but its crown and root overall shapes are very similar to those of $\mathrm{P}^{1}$ attributed to To. traversei (Fig. 6A-D). No $\mathrm{P}^{2}$ was found in the material initially collected by Traverse (Gingerich \& Cappetta, 2014). The $\mathrm{P}^{3}$ KPG-M39 is characterised by a posterolingual swelling reminiscent of the presence of a protocone, as well as a crest that joins the paracone and the lingual cingulum anteriorly. We observed a faint distolingual swelling close to the enamel-dentine junction, but not to the extent of the $\mathrm{P}^{3}$ of To. traversei. The anterior end of the mesial carina of $\mathrm{P}^{4}$ is broken on both sides. Gingerich \& Cappetta, (2014) observed no trace of metacone on the two tooth fragments identified as $\mathrm{P}^{4}$, which they considered as a diagnostic feature of To. traversei. However, we reattributed one of these teeth (KPG-M59) as a probable $\mathrm{P}^{3}$ since its crown is more symmetrical with an obtuse angle of the paracone in lateral view. The other $\mathrm{P}^{4}$ attributed to To. traversei (KPG-M 134, Fig. 6F and $\mathrm{H}$ ) resembles that of the new specimen but lacks a metacone. However, a small groove on the lingual surface of KPG-M 134 is suggestive of the presence of an incipient metacone (Fig. $6 \mathrm{H}$ ). The $\mathrm{M}^{1}$ and $\mathrm{M}^{3}$ are virtually unknown in the original material of 
To. traversei and teeth from these positions are very fragmentary in KPO1. As the $\mathrm{M}^{2}$ of To. traversei, the left $\mathrm{M}^{2}$ of KPO1 is thee-rooted, the most posterior roots being largely confluent. The doubled preparacrista is visible on the 3D reconstruction (Fig. 6M); it is low as in KPG-M4 (Fig. $6 \mathrm{~N}$ ) but this feature shows a significant intraspecific variation on the $\mathrm{M}^{2}$ of To. traversei (Fig. 6N and $\mathrm{O}$ ). In occlusal view, the angulation of the anterior and posterior margins of the crown relative to its lateral margin resembles that described on the $\mathrm{M}^{2}$ of To. traversei (Fig. $6 \mathrm{~K}$ and L). The distal margin is straight rather than concave, which was considered as a distinctive feature of To. traversei with regards to other protocetid species. The mesial margin appears more concave on KPO1 than on KPG-M4 (Fig. 6L), but the enamel of the protocone is highly worn on the former (Fig. 2), which could partly explain such a difference. Pending future discoveries that would enable to assess the extent of dental variation among protocetid taxa, and considering the size and morphological differences observed between KPO1 and the material attributed to To. traversei, we propose to assign the new Togolese specimen to Togocetus cf. traversei.

At first glance, it appears rather puzzling to find the most basal protocetid more than $7,000 \mathrm{~km}$ away from the hypothetical cradle of the family in the Indo-Pakistan region (int. al. Gingerich et al., 1994; Gingerich et al., 2001a; Marx et al., 2016). Nevertheless, this position was consistently retrieved regardless of the inclusion or not of Togocetus into the analysis (Fig. 7 and Saupplemental Figs. 4-5), and whether or not KPO1 was associated with one of the three bullar morphotypes from Kpogamé (Supplemental Figs. 6-8). Our cladistic results confirmed that Togocetus and KPO1 display a large proportion of plesiomorphic features. Gingerich \& Cappetta (2014) also initially described most of Togocetus specificities as ancestral features, notably its overall size, the presence of a small mandibular canal, and the presence of a metaconid on $\mathrm{M}_{1}$. According to these authors, the absence of the fovea capitis femoris represents the only derived 
character of Togocetus. On the one hand, one could consider the association between the dental material of To. traversei and the sole femur to be unnatural due to the isolated nature of the Togolese remains. The absence of the fovea capitis femoris is indeed rather uncommon among protocetids (only known in Natchitochia; Uhen, 2014) and has been proposed to be a diagnostic feature for the family Remingtonocetidae (Gingerich et al., 1995a: table 8). In our phylogenetic analysis, however, the absence of the fovea capitis femoris $\left(148^{0} ; \mathrm{RI}=0.50\right.$; ACCTRAN $)$ represents an ambiguous synapomorphy for the clade gathering the remingtonocetids with the more derived cetaceans (node $\mathrm{C} 2$ ), which indicates that this feature is also likely to be plesiomorphic for protocetids. Thus, the association of morphological features first recognised as diagnostic for Togocetus also leads toward a recognition of a basal position for this taxon and is coherent with its association with KPO1. Such basal position is also consistent with the middle Lutetian age (planktonic foraminiferal zone P11) proposed for Kpogamé (Gingerich \& Cappetta, 2014). If confirmed, the absence of the fovea capitis femoris in Togocetus also indicates that it was most likely a foot-powered swimmer (Gingerich \& Cappetta, 2014; see also Adam, 2009; Bebej et al., 2015), already well able to cross part of the Tethys Sea to reach Africa from the Indo-Pakistan region, in a similar way than did the remingtonocetid Rayanistes (Bebej et al. 2015). Another basal protocetid, Peregocetus, was in fact described even further away from IndoPakistan in middle Eocene deposits of Peru (Lambert et al., 2019). Consequently, our results confirmed that the anatomical adaptations necessary for the colonization of fully aquatic environments were acquired very early during the evolutionary history of archaeocetes, in a clade including at least remingtonocetids and more derived cetaceans (node C2). Our discovery demonstrates that much more is to be learnt about the early radiation of these semi-aquatic archaeocetes and that a more precise temporal and geographic resolution is a prerequisite to establish the chronology of their dispersion and diversification. 


\section{Protocetid diversity in the Togolese phosphate basin}

Based on dental and postcranial remains, Gingerich \& Cappetta (2014) described three protocetid taxa, including Togocetus, from Kpogamé. In turn, following the redescription of the auditory region remains from Kpogamé, Mourlam \& Orliac (2018) identified three bullar morphotypes ( $\alpha, \beta$ and $\gamma$ ), which they proposed likely belonged to three protocetid genera. In addition, based on their phylogenetic analysis, these authors were able to associate the morphotype $\alpha$ to ?Carolinacetus sp. and the morphotype $\beta$ to Togocetus (Mourlam \& Orliac, 2018). They were unable, however, to identify the third morphotype $(\gamma)$ in a systematic point of view.

In the light of our present phylogenetic analysis, the identification of the bullar morphotype $\alpha$ as ?Carolinacetus sp. is consistent with previous results (Mourlam \& Orliac, 2018). Indeed, the morphotype $\alpha$ is found within an unresolved clade (node Pr5) that contains Carolinacetus (Geisler et al., 2005), and cf. Carolinacetus sp. from Senegal (SNTB 2011-01; Vautrin et al., 2020). In addition, among the 28 characters that Carolinacetus and the morphotype $\alpha$ have in common $($ Sha $=32.18 \%$ for Carolinacetus $)$, only one state of character differs $(\operatorname{Sim}=$ 96.43\%): the shape of the fossa for the tensor tympani muscle on the petrosal $(37 ; \mathrm{RI}=0.86)$. That said, Tupelocetus (Gibson et al., 2019) is also present in this polytomy (node Pr5). This recently described protocetid comes from the same locality as Carolinacetus in South Carolina (Geisler and Luo, 2005). Tupelocetus and Carolinacetus present some size variations alongside morphological differences on the occiput, parietal and basicranium that led Gibson et al. (2019) to consider Tupelocetus as a separate genus. However, based on these authors agreement subtree resulting from their phylogenetic analysis, Tupelocetus and Carolinacetus are found as sister taxa 
within a trifurcation (Gibson et al., 2019: Fig. 5). Furthermore, based on our phylogenetic analysis, among the 12 characters shared by Tupelocetus and Carolinacetus, only two of them present a variation of character's state $(\operatorname{Sim}=83.33 \%$; but with a very low shared index for Carolinacetus: Sha $=13.79 \%)$ : the posterior end of the ascending process of the premaxilla $(8 ; \mathrm{RI}$ $=0.40)$ and the length of the external auditory meatus $(47 ; \mathrm{RI}=0.53)$. Thus, while Carolinacetus and Tupelocetus likely represent two different taxa, we cannot exclude that Tu. palmeri rather represents another species of Carolinacetus due to geographic and anatomical similarities. Further work on the bony labyrinth of these two taxa, along with the study of the numerous protocetid specimens found in this north American locality (Gibson et al., 2019), would certainly help to clarify this issue.

The poorly documented morphotype $\beta$ has been initially associated with Togocetus on the ground of phylogenetic congruence (Mourlam \& Orliac, 2018). Based on its 14 phylogenetic characters available (i.e. only $8.4 \%$ of the characters of the matrix), the morphotype $\beta$ appears to be the most derived morphotype from Kpogamé, with, for instance, the presence of a medial keel on the tympanic bulla $\left(64^{1} ; \mathrm{RI}=0.33\right)$ and the absence of the second $\left(71^{0} ; \mathrm{RI}=0.80\right)$ and third $\left(72^{0} ; \mathrm{RI}=0.75\right)$ tuberosities of the involucrum. This phylogenetic position is corroborated with the present phylogenetic analysis. However, due to modification of the definition of some characters and character states (see Supplemental Text 1), the phylogenetic position of Togocetus "earless" (i.e. coded without any characters from the auditory region) drastically changed to find itself as the first offshoot of the protocetid. Consequently, contra Mourlam \& Orliac (2018), the morphotype $\beta$ cannot be identified as the ear region of Togocetus and probably belongs to one of the most derived protocetid known so far. 
Although the third bullar morphotype $\gamma$ is the best documented out of the three from Kpogamé, it belongs to an unknown protocetid taxon. Some of the preserved squamosal remains associated to the morphotype $\gamma$ allows some scarce comparison with that of KPO1. Thus, it is interesting to note that they both share a unique feature within protocetids (Fig. 4C): the overall shape of their entoglenoid process is that of a hat $\left(46^{3} ; \mathrm{RI}=0.86\right)$ with a foramen ovale that deeply excavates the anterolateral part of the entoglenoid process. However, the morphotype $\gamma$ and KPO1 also exhibit some differences: while the posterolateral part of the entoglenoid process of KPO1 is convex, the same structure is concave for the morphotype $\gamma$. Although it cannot be excluded that this concavity is partially weathered, its morphology matches that of the thin anterolateral wall of the tympanic bulla, suggesting that its shape is nevertheless fairly well preserved (Supplemental Fig. 2). In addition, the vascular groove of the morphotype $\gamma$ is wider and deeper than that of KPO1. Finally, according to the results of our phylogenetic analysis, the morphotype $\gamma$ and KPO1 clearly occupy distinct parts of the tree and therefore, they most likely belong to two different protocetid genera. The systematic attribution of the morphotype $\gamma$ is becoming clearer in the light of our phylogenetic analysis. Indeed, contrary to the previous analysis (Mourlam \& Orliac, 2018), the morphotype $\gamma$ is now found in a clade (node Pr 10) as the sister taxa of Protocetus. Among the 36 characters shared by Protocetus and the morphotype $\gamma$ $($ Sha $=32.72 \%$ for Protocetus $)$, six of them present a variation of character's state $($ Sim $=$ $83.33 \%)$ : the position of the secondary facial foramen $(41 ; \mathrm{RI}=0.50)$, the shape of the entoglenoid process $(46 ; \mathrm{RI}=0.86)$, the shape and orientation of the tip of the sigmoid process $(52 ; \mathrm{RI}=0.50)$, the presence or not of an articulation between the medial edge of the tympanic bulla and the basioccipital $(54 ; \mathrm{RI}=0.25)$, and the presence or not of the third $(72 ; \mathrm{RI}=0.75)$ and fifth $(74 ; \mathrm{RI}=0.50)$ tuberosities of the involucrum. Although these morphological differences clearly highlight that Protocetus and the morphotype $\gamma$ likely represent two distinct taxa, it 
remains unclear whether the morphotype $\gamma$ represents another species of Protocetus or a genus on its own. Here again, the study of the bony labyrinth of Protocetus, if available (Arlt et al., 2018), could shed more light on that issue.

The middle ear ossicles of protocetids exhibit a mosaic pattern of plesiomorphic and derived characters (Mourlam \& Orliac, 2019) highlighting a differential of tempo and mode of evolution (Simpson, 1944) within the auditory region. So far, this assertion has not been formally tested for the protocetid tympanic bullae. Consequently, it is legitimate to wonder if one of the three bullar morphotypes could actually be associated with Togocetus and, because of evolutionary convergences and the absence of common characters with Togocetus, it is found in a more derived position instead. Thus, we performed four phylogenetic analyses to compare the four possible hypotheses: Togocetus "earless" and Togocetus associated with one of the three morphotypes (Supplemental Figs. 5-8). Regardless of the hypothesis tested, Togocetus is systematically found to be the first offshoot of the protocetids, the topology of the consensus tree being unequally resolved for the protocetid depending on the tested hypothesis. The hypothesis that presents the less polytomies is to consider the morphotype $\beta$ as being Togocetus auditory region (Supplemental Fig. 6). Furthermore, the consensus tree of this " $\beta$ hypothesis" has a length of 689 steps and is therefore the most parsimonious consensus tree out of the four hypotheses. However, this hypothesis includes one operational taxonomic unit less than the Togocetus "earless" hypothesis. Thus, considering the average step by taxon (ast), the " $\beta$ hypothesis" is only the second most parsimonious hypothesis $($ ast $=16.02)$ and the "earless hypothesis" remains the most parsimonious one (ast $=15.70)$. This leads us to consider that, so far, the auditory region of Togocetus remains uncertain. Therefore, until the discovery of new in situ material of the ear 
region, we consider that there is potentially a minimum of four protocetid taxa at Kpogamé: Togocetus, ?Carolinacetus sp. and two indetermined protocetids (morphotypes $\beta$ and $\gamma$ ).

\section{Depositional environment and protocetid distribution in Africa}

Protocetids have a wide geographical distribution, being known from Asia, Africa, North, and South America (de Muizon, 2009; Gingerich, 2010; Uhen, 2010; Gingerich et al., 2019), and were only found in late middle Eocene to early Priabonian formations (Gingerich et al., 2019). However, the distribution of Eocene African protocetids remains incomplete. So far, only Pappocetus lugardi was described in two distinct Bartonian contemporary basins in Nigeria (Andrews, 1920) and Morocco (Gingerich \& Zouhri, 2015). The other recognized species remain basin-specific and no taxonomic similarity is observed between contemporary sites of the middle Lutetian (Egypt: Protocetus atavus, Fraas, 1904; and Togo: ?Carolinacetus, Togocetus traversei, protocetids indeterminate, Gingerich \& Cappetta, 2014; Mourlam \& Orliac, 2018), late Lutetian (Senegal: cf. Carolinacetus, protocetids indeterminate, Hautier et al., 2014; Vautrin et al., 2020; and Egypt : Aegyptocetus tarfa, Bianucci \& Gingerich, 2011), and Priabonian (Egypt: Aegicetus gehennae, Gingerich et al., 2019). Besides possible age uncertainties, differences in depositional environments might explain a substantial part of the distribution and diversity of protocetid taxa. African protocetids known from Lutetian deposits are all associated with environments characterized by biochemical sedimentation (phosphate or carbonate) linked to a significant supply of nutrients, notably through upwellings (Slansky 1962, 1980; Lucas et al., 1979; Johnson, 1987; Johnson et al., 2000; Haddi, 2014) .

In the Togolese basin, the phosphatogenesis period was favourable to the expansion of early cetaceans (Gingerich \& Cappetta, 2014) and other marine vertebrates (Cappetta \& Traverse, 
1988; Bourdon \& Cappetta, 2012). Deposits are mainly composed of phosphates, carbonates, and clays, with cetacean remains being exclusively found in the formers. The KPO1 specimen was found in a phosphate carbonate layer containing shark coprolites and teeth as well as foraminifera, which all characterize a rich marine environment. This environment is marked by an important contribution of continental minerals such as kaolinite, quartz and traces of plants marked by the presence of pollens (Johnson et al., 2000) as well as some remains of terrestrial mammals (Gingerich \& Cappetta, 2014), indicating the proximity of the coast. Using bioclasts, mineralogy (quartz, kaolinite) and pollens to characterise the depositional environment of the phosphates of Kpogamé, Johnson (1987) and Johnson et al. (2000) proposed a shallow marine environment of average salinity with moderate deposition energy. Carbon and oxygen isotopic data also indicated that Togolese protocetids lived in nearshore environments and were capable of osmoregulation in the marine environment (Clementz et al., 2006).

The protocetids known from Nigeria, Senegal, Egypt, and Morocco were all found in middle Lutetian to early Priabonian deposits characterizing nearshore environments. P. lugardi, was found in the Bartonian Ameki Formation in southern Nigeria (40.4 to 37.2 Myr; Arua, 1988, 1991; Arua \& Rao, 1987; Odumodu \& Nfor, 2012; Onuigbo et al., 2020), which was deposited in an environment varying from marine to estuarine (Reyment, 1965). Based on foraminifera assemblages, Arua (1988) also proposed an environment ranging from near-shore to the subtidal and intertidal zones. More recently, Odumodu \& Nfor (2012) suggested that the Ameki Formation was deposited on the marine continental shelf in the open marine neritic zone based on the study of nautiloids. The indeterminate protocetids of Senegal (Hautier et al., 2014; Vautrin et al., 2020) were found in the Taïba formation dated from the late Lutetian to the Bartonian based on planktonic foraminifera (Brancart \& Flicoteaux, 1971; Brancart, 1977; Flicoteaux, 1975, 
1982; Samb, 2008) and sharks (Hautier et al., 2012). The Taïba formation mainly consists of phosphate and carbonate deposits (Samb, 2008; Hautier et al., 2014), which were proposed to represent a very shallow circalittoral marine environment (Pascal, 1987). In Egypt, protocetids were found in both Lutetian (Pr. atavus, Ag. tarfa) and earliest Priabonian (Ae. gehennae) formations. The middle Lutetian Jebel Mokattam formation that yielded Pr. atavus was proposed to be deposited in open and shallow marine environments (Gingerich, 1992; Safia et al., 2019). Aegyptocetus tarfa was found in the Gebel Hof Formation, which consists of limestone-rich Nummulites (Bianucci \& Gingerich, 2011). The wackestone sandy nummulitic microfacies (Sallam et al., 2015) indicates a deposit in an open marine platform, with free circulation and receiving small quantities of detrital sand grains. Water depth was then tens of meters within the euphotic zone (Sallam et al., 2015). In southwest Morocco, protocetids were found in the Bartonian sandstones of the Gueran Formation (Gingerich \& Zouhri, 2015). Based on the marine carbonates accumulating further offshore northwest of Gueran, the depositional environment of the whole formation was reconstructed as a neritic zone (Ranke et al., 1982).

No protocetids have been reported from early Lutetian African formations. This could indicate that they were not yet present in early Lutetian Africa despite the presence of favourable depositional environments. In the Togolese basin, like in Egyptian and Senegalese basins, the early Lutetian period corresponds to a regressive phase (Johnson, 1987; Johnson et al., 2000; Da Costa, 2005) followed by the deposition of phosphates, carbonates, and sandstones. As previously mentioned, such deposits characterize shallow, near-shore marine environments, as it almost always the case for other protocetid taxa worldwide (Gingerich et al., 2001a; Gingerich et al., 2001b; Geisler et al., 2005; Thewissen et al., 2009; Uhen, 2010; Uhen et al., 2011; Gao \& Ni, 2015; Lambert et al., 2019). On the one hand, this might indicate that protocetids were restricted 
to coastal waters, being only able to migrate along continuous shorelines. On the other hand, recent discoveries demonstrated that some protocetids were undoubtedly great travellers likely capable of crossing vast oceanic areas (Lambert et al., 2019; Vautrin et al., 2020), with shallow environments being simply more favourable for preserving their remains.

\section{CONCLUSION}

We report here the first discovery of a partial cetacean cranium from middle Eocene phosphates deposits of Togo. Cranial and dental comparisons, 3D reconstructions, and cladistic analyses have shown that the new specimen from Togo differs from known protocetids, particularly African ones like Aegyptocetus tarfa, Aegicetus gehennae, and Protocetus atavus. The new specimen displays a number of morphological resemblances with Togocetus. Phylogenetic analyses recovered the new specimen close to Togocetus as the first offshoot of protocetids. This basal position is consistent with the Lutetian age of the Togolese phosphate deposits. These results enabled us to assign the specimen to Togocetus cf. traversei, so that it represents the first and most complete cranial remain of Togocetus. We showed that Kpogamé phosphates potentially enclosed at least four protocetid taxa, which confirms the great diversity of this family and its wide geographical distribution during the middle Eocene.

\section{Acknowledgements}

We thank the Department of Geology of the University of Lomé. We also warmly thank M. Abalo Kézié, general director of SNPT, as well as employees from these companies, M. Bikiliniwé Ekpao, M. Kudzo D’almeida, M. Adodo Goe Akue, M. Mazama-Esso Bidabi, M. Laba Minza, M. Sizing Adom, M. Kossi Karim and M. Fan-Name Kanfeli, for providing access 
and sampling permissions. We are grateful to Maëva J. Orliac (ISEM) for the 3D surface of the basicranium of morphotype $\gamma$ (UM-KPG-M 73) and to Kathlyn Smith (Georgia Southern University) for the picture of Georgiacetus' basicranium (GSM 350). We thank Camille Auclair (Kraniata, France, www.kraniata.com) for the exquisite preparation of the specimen KPO1. 3D data acquisition was performed using the $\mu \mathrm{CT}$ facilities of the MRI platform member of the national infrastructure France-Bio Imaging supported by the French National Research Agency (ANR-10-INBS-04, 'Investments for the future') and of the Labex CEMEB (ANR-10-LABX0004) and NUMEV (ANR-10-LABX-0020). This study is part of the PaleonTogo project, which is partly supported by a CNRS PICS grant (n8229424) and the National Geographic Society (grant NGS-72222R-20). 


\section{References}

Adam, P. J. 2009. Hind limb anatomy, p. 562 - 565. In W. F. Perrin, B. Wrsig, and J. G. M. Thewissen (eds.), Encyclopedia of Marine Mammals, Second Edition. Academic-Elsevier Press, San Diego.

Andrews, C. W. 1920. A description of new species of zeuglodont and of leathery turtle from the Eocene of southern Nigeria. Procedings of the zoological Society of London, 89, doi: https://doi.org/ 10.1111/j.1096-3642.1919.tb02124.x 27.

\section{Arlt, T., Wieder, F., Ritsche, I., Hilger, A., Kardjilov, N., Fahlke, J. M., Hampe, O. \&} Manke, I. 2018. X-ray and neutron tomography on the bony inner ear of baleen whales. Materials Testing, 60, 173-178, doi: 10.3139/120.111129.

Arua, I. 1988. Paleoecology of the Eocene Ameki Formation of southeastern Nigeria. Journal of African Earth Sciences, 7, 925-932, doi: 10.1016/0899-5362(88)90007-3.

Arua, I. 1991. The trace fossil Teredolites longissimus in calcareous concretions from the Eocene Ameki Formation, southeastern Nigeria. Journal of African Earth Sciences, 12, 605608, doi: 10.1016/0899-5362(91)90022-Q.

Arua, I. \& Rao, V. R. 1987. New stratigraphic data on the Eocene Ameki Formation, southeastern Nigeria. Journal of African Earth Sciences, 6, 391-397, doi: 10.1016/08995362(87)90082-0.

Bajpai, S. \& Thewissen, J. G. M. 1998. Middle Eocene Cetaceans from the Harudi and Subathu Formations of India. In Thewissen, J. G. M. (ed.),The Emergence of Whales, Evolutionary Patterns in the Origin of Cetacea. Plenum Press, New York, 213-233, doi: 10.1007/978-14899-0159-0_7. 
Bajpai, S. \& Thewissen, J. G. M. 2014. Protocetid cetaceans (Mammalia) from the Eocene of India. Palaeontologia Electronica, 17, 1-19.

Bebej, R. M. \& Smith, K. M. 2017. Lumbar mobility in archaeocetes (Mammalia: Cetacea) and the evolution of aquatic locomotion in the earliest whales. Zoological Journal of the Linnean Society, 182, 695-721, doi: 10.1093/zoolinnean/zlx058.

Bebej, R. M., Zalmout, I. S., El-Aziz, A. A. A., Antar, M. S. M. \& Gingerich, P. D. 2015. First remingtonocetid archaeocete (Mammalia, Cetacea) from the middle Eocene of Egypt with implications for biogeography and locomotion in early cetacean evolution. Journal of Paleontology, 89, 882-893, doi: 10.1017/jpa.2015.57.

Bianucci, G. \& Gingerich, P. D. 2011. Aegyptocetus tarfa, n. gen. et sp. (Mammalia, Cetacea), from the middle Eocene of Egypt: clinorhynchy, olfaction, and hearing in a protocetid whale. Journal of Vertebrate Paleontology, 31, 1173-1188, doi: 10.1080/02724634.2011.607985.

Bourdon, E. \& Cappetta, H. 2012. Pseudo-toothed birds (Aves, Odontopterygiformes) from the Eocene phosphate deposits of Togo, Africa. Journal of Vertebrate Paleontology, 32, 965970, doi: 10.1080/02724634.2012.676113.

Brancart, R. Y. 1977. Etude micropaléontologique et stratigraphique du Paléogène sur le flanc occidental du horst de Ndiass et dans la région de Taïba. Thèse Doctorat de 3ème cycle de l’Université de Provence. 1, 89.

Brancart, R. Y. \& Flicoteaux, R. 1971. Age des formations phosphatees de Lam Lam et de Taiba (Senegal occidental). Données micropaléontologiques, conséquences stratigraphiques et paléogéographiques. Bulletin de la Société Géologique de France, 7, 399-408, doi: 10.2113/gssgfbull.S7-XIII.3-4.399.

Bremer, K. 1994. Branch support and tree stability. Cladistics, 10, 295-304. 
Buchholtz, E. A. 1998. Implications of vertebral morphology for locomotor evolution in early Cetacea. In: Thewissen J.G.M. (eds) The Emergence of Whales. Advances in Vertebrate Paleobiology, vol 1. Springer, Boston, MA., 325-351, doi: 10.1007/978-1-4899-0159-0_11.

Buchholtz, E. A. 2007. Modular evolution of the Cetacean vertebral column. Evolution and Development, 9, 278-289, doi: 10.1111/j.1525-142X.2007.00160.x.

Cappetta, H. \& Traverse, M. 1988. Une riche faune de Sélaciens dans le bassin à phosphate de Kpogamé-Hahotoé (Éocène moyen du Togo): Note préliminaire et précisions sur la structure et l'âge du gisement. Geobios, 21, 359-365, doi: 10.1016/S0016-6995(88)80058-5.

Clementz, M. T., Goswami, A., Gingerich, P. D. \& Koch, P. L. 2006. Isotopic records from early whales and sea cows: contrasting patterns of ecological transition. Journal of Vertebrate Paleontology, 26, 355-370, doi: 10.1671/0272-4634(2006)26.

Colonna-Cimera. 1961. Note sur le démarrage de l'exploitation du gisement de phosphate du bas-Togo. Rapport de la Direction générale des mines et de la géologie, $12 \mathrm{p}$.

Da Costa, P. Y. D. 2005. Biostratigraphie et paléogéographie du bassin côtier du Togo: tome II, figures, tableaux, planches. Thèse, Université de Lomé, 201p.

Da Costa, P. Y. D., Affaton, P., Salaj, J., Johnson, A. K. C. \& Seddoh, K. 2013. Biozonation des formations sédimentaires du bassin côtier du Togo (Afrique de l'ouest). Revue Ivoirienne des Sciences et Technologie, 21-22, 45-73.

Darlu, P. \& Tassy, P. 1993. La reconstruction phylogénétique: concepts et méthodes. 258p.

de Muizon, C. 2009. L'origine et l'histoire évolutive des Cétacés. Comptes Rendus - Palevol, 8 , 295-309, doi: 10.1016/j.crpv.2008.07.002.

de Muizon, C., Billet, G., Argot, C., Ladevèze, S. \& Goussard, F. 2015. Alcidedorbignya inopinata, a basal pantodont (Placentalia, Mammalia) from the early Palaeocene of Bolivia: anatomy, phylogeny and palaeobiology. Geodiversitas, 37, 397-631, doi: 
$10.5252 / \mathrm{g} 2015 \mathrm{n} 4 \mathrm{a} 1$.

Farris, J. S. 1970. Methods for computing wagner trees. Systematic zoology, 19, 83-92, doi: $10.2307 / 2412028$.

Farris, J. S. 1989. The retention index and the rescaled consistency index. Cladistics, 5, 417419, doi: 10.1111/j.1096-0031.1989.tb00573.x.

Flicoteaux, R. 1975. Sur l'attribution à l'Eocène moyen des couches calcaires et argilophosphatées de Pallo (Plateau de Thiès, Sénégal occidental). Bulletin de la Société Géologique de France, 17, 430-434, doi: 10.2113/gssgfbull.S7-XVII.3.430.

Flicoteaux, R. 1982. Genèse des phosphates alumineux du Sénégal occidental. Étapes et guides de l'altération. Mémoires de la Société Géologique de l'Université de Strasbourg, 67, 1229.

Fordyce, R. E. 1992. Cetacean evolution and Eocene/Oligocene environments in Prothero, D., Berggren, W. (eds), Eocene- Oligocene Climatic and Biotic Evolution: U.S.A. Princeton University Press, 368-381.

Fordyce, R. E. 2018. Cetacean evolution. Encyclopedia of Marine Mammals, 180-185, doi: 10.1016/b978-0-12-804327-1.00088-1.

Fraas, E. M. 1904. Neue Zeuglodonten aus dem unteren Mitteleocan vom Mokattam bei Cairo. Neues Jahrbuch fur Geologie und Palaontologie, 10, 199-220.

Gao, H.-Y. \& Ni, X.-J. 2015. Diverse stem cetaceans and their phylogenetic relationships with mesonychids and artiodactyls. Vertebrata Palasiatica, 53, 153-176.

Geisler, J. H. \& Luo, Z.-X. 1998. Relationships of Cetacea to terrestrial ungulates and the evolution of cranial vasculature in cete. in J. G. M. Thewissen (ed.) The emergence of whales: evolutionary patterns in the origin of Cetacea. Plenum Press, New York, 163-212, doi: 10.1007/978-1-4899-0159-0_6. 
Geisler, J. H., Sanders, A. E. \& Luo, Z.-X. 2005. A new protocetid whale (Cetacea:

Archaeoceti) from the late middle Eocene of South Carolina. American Museum Novitates, $1-65$.

Gibson, M. L., Mnieckowski, J. \& Geisler, J. H. 2019. Tupelocetus palmeri, a new species of protocetid whale (Mammalia, Cetacea) from the middle Eocene of South Carolina. Journal of Vertebrate Paleontology, 38, 1-11, doi: 10.1080/02724634.2018.1555165.

Gingerich, P. D. 1992. Marine mammals (Cetacea and Sirenia) from the Eocene of Gebel Mokattam and Fayum, Egypt: stratigraphy, age and paleoenvironments. University of Michigan Papers on Paleontology, 30, 1-84.

Gingerich, P. D. 2010. Cetacea. In Wederlin L. and Sanders W. J. eds, Cenozoic mammals of Africa, University of California Press, 873-899.

Gingerich, P. D. \& Cappetta, H. 2014. A new archaeocete and other marine mammals (Cetacea and Sirenia) from lower middle Eocene phosphate deposits of Togo. Journal of Paleontology, 88, 109-129, doi: 10.1666/13-040.

Gingerich, P. D. \& Zouhri, S. 2015. New fauna of archaeocete whales (Mammalia, Cetacea) from the Bartonian middle Eocene of southern Morocco. Journal of African Earth Sciences, 111, 273-286, doi: 10.1016/j.jafrearsci.2015.08.006.

Gingerich, P. D., Raza, S. M., Arif, M., Anwar, M. \& Zhou, X. 1993. Partial skeletons of Indocetus ramani (Mammalia, Cetacea) from the lower middle Eocene Domanda shale in the Sulaiman Range of Punjab (Pakistan). Museum of Paleontology. University of Michigan., 28, 393-416.

Gingerich, P. D., Raza, S. M., Arif, M., Anwar, M. \& Zhou, X. 1994. New whale from the Eocene of Pakistan and the origin of cetacean swimming. Nature, 368, 844-847.

Gingerich, P.D., Arif, M. \& Clyde, W. C. 1995a. New archaeocetes (Mammalia, Cetacea) from 
the middle Eocene Domanda Formation of the Sulaiman range,Punjab (Pakistan). Contributions from the Museum of Paleontology - University of Michigan, 29, 291-330.

Gingerich, P. D., Arif, M., Bhatti, M. A., Raza, H. A. \& Raza, S. M. 1995b. Protosiren and Babiacetus (Mammalia, Sirenia and Cetacea) from the middle Eocene Drazinda Formation, Sulaiman Range, Punjab (Pakistan). Contributions from the Museum of Paleontology. University of Michigan., 29, 331-357.

Gingerich, P. D., Ul-Haq, M., Khan, I. H. \& Zalmout, I. S. 2001b. Eocene stratigraphy and archaeocete whales (Mammalia, Cetacea) of Drug Lahar in the eastern Sulaiman Range, Balochistan (Pakistan). Contributions from the Museum of Paleontology - University of Michigan, 30, 269-319.

Gingerich, P. D, Ul-Haq, M., Zalmout, I. S., Khan, I. H. \& Malkani, M. S. 2001a. Origin of whales from early artiodactyls: hands and feet of Eocene Protocetidae from Pakistan. Science, 293, 2239-2242, doi: 10.1126/science.1063902.

Gingerich, P. D., Zalmout, I. S., Ul-Haq, M. \& Bhatti, M. A. 2005. Makaracetus bidens, a new protocetid archaeocete (Mammalia, Cetacea) from the early middle Eocene. Contributions from the Museum of Paleontology - University of Michigan, 31, 197-210.

\section{Gingerich, P. D., Ul-Haq, M., Von Koenigswald, W., Sanders, W. J., Smith, B. H. \&}

Zalmout, I. S. 2009. New protocetid whale from the middle Eocene of Pakistan: birth on land, precocial development, and sexual dimorphism. PLoS ONE, 4, 20, doi: 10.1371/journal.pone.0004366.

Gingerich, P. D., Antar, M. S. M. \& Zalmout, I. S. 2019. Aegicetus gehennae, a new late Eocene protocetid (Cetacea, Archaeoceti) from Wadi Al Hitan, Egypt, and the transition to tail-powered swimming in whales. PLoS ONE, 14, 1-56, doi:

10.1371/journal.pone.0225391. 
Goëffon, A., Richer, J. \& Hao, J. 2010. Heuristic methods for phylogenetic reconstruction with maximum parsimony. Algorithms in Computatinal Molecular Biology. Hoboken, NJ, USA: John Wiley \& Sons, INc, 579-597, doi: 10.1002/9780470892107.ch26.

Gol'din, P. \& Zvonok, E. 2013. Basilotritus uheni, a new cetacean (Cetacea, Basilosauridae) from the late middle Eocene of eastern Europe. Journal of Paleontology, 87, 254-268, doi: 10.1666/12-080r.1.

Haddi, H. E. L. 2014. Les silicifications de la série phosphatée des Ouled Abdoun (Maastrichtien-Lutétien, Maroc) : sédimentologie, minéralogie, géochimie et contexte génétique. Université Hassan II de Casablanca, 149 p.

Hautier, L., Sarr, R., Tabuce, R., Lihoreau, F., Adnet, S., Domning, D. P., Samb, M. \& Hameh, P. M. 2012. First prorastomid sirenian from Senegal (Western Africa) and the Old World origin of sea cows. Journal of Vertebrate Paleontology, 32, 1218-1222, doi: 10.1080/02724634.2012.687421.

Hautier, L., Sarr, R., Lihoreau, F., Tabuce, R. \& Marwan Hameh, P. 2014. First record of the family Protocetidae in the Lutetian of Senegal (West Africa). Palaeovertebrata, 38, 1-7, doi: $10.18563 /$ pv.38.2.e2.

Hector, J. 1881. Notes on New Zealand Cetacea, recent and fossil. Transactions and Proceedings of the Royal Society of New Zealand, 13, 434-436.

Hernández-Cisneros, A. E. \& Tsai, C. 2016. A possible enigmatic kekenodontid (Cetacea, Kekenodontidae) from the Oligocene of Mexico. Paleontologia Mexicana, 5, 147-155.

Hulbert, R. C., Petkewich, R. M., Bishop, G. A., Bukry, D. \& Aleshire, D. P. 1998. A new middle Eocene protocetid whale (Mammalia: Cetacea: Archaeoceti) and associated biota from Georgia. Journal of Paleontology, 72, 907-927.

Johnson, A. K. C. 1987. Le Bassin côtier à phosphate du Togo (Maastrichtien-Eocène moyen) 
Universités de Bourgogne (France) et du Benin (Togo). 365 p.

Johnson, A. K. C., Rat, P. \& Lang, J. 2000. Le bassin sédimentaire à phosphate du Togo (Maastrichtien-Eocene): stratigraphie, environnements et évolution. Journal of African Earth Sciences, 30, 183-200, doi: 10.1016/S0899-5362(00)00015-4.

Kassegne, K. E., Mourlam, M. J., Guinot, G., Amoudji, Y. Z., Martin, J. E., Togbe, K. A., Johnson, A. K., Hautier, L. 2021. 3D models related to the publication : First partial cranium of Togocetus from Kpogamé (Togo) and the protocetid diversity in the Togolese phosphate basin. MorphoMuseuM. Submitted.

Kellogg, R. 1936. A review of the Archaeoceti. Carnegie Institution of Washington publications, 482, 19, 1-366, doi: 10.2307/1374291.

Kluge, A. G. \& Farris, J. S. 1969. Quantitative phyletics and the the evolution of anurans. Systematic Zoology, 18, 1-32.

Lambert, O., Bianucci, G., Salas-Gismondi, R., Di Celma, C., Steurbaut, E., Urbina, M. \& de Muizon, C. 2019. An amphibious whale from the middle Eocene of Peru reveals early South Pacific dispersal of quadrupedal cetaceans. Current Biology, 29, 1352-1359.e3, doi: 10.1016/j.cub.2019.02.050.

Lebrun, R. 2018. Morphodig, an open-source 3D freeware dedicated to biology. 5th International Paleontology Congress, 399, 47.

Lucas, J., Prévôt, L. \& Mountassir, M. E. 1979. Les phosphorites rubéfiées de Sidi Daoui, transformation météorique locale du gisement de phosphate des Ouled Abdoun (Maroc). Sciences Geologiques, 32, 21-38.

Luo, Z.-X. \& Gingerich, P. D. 1999. Terrestrial Mesonychia to aquatic cetacea: transformation of the basicranium and evolution of hearing in whales. University of Michigan Papers on Paleontology, 369, 31-98, doi: 10.1017/CBO9781107415324.004. 
Martínez-Cáceres, M., Lambert, O. \& de Muizon, C. 2017. The anatomy and phylogenetic affinities of Cynthiacetus peruvianus, a large Dorudon -like basilosaurid (Cetacea, Mammalia) from the late Eocene of Peru. Geodiversitas, 39, 7-163, doi: $10.5252 / \mathrm{g} 2017 \mathrm{n} 1 \mathrm{a} 1$.

Marx, F. G., Lambert, O. \& Uhen, M. D. 2016. Cetacean paleobiology. Chichester, UK: John Wiley \& Sons Ltd., 307.

Mead, J. G. \& Fordyce, R. E. 2009. The therian skull : a lexicon with emphasis on the odontocetes. Smithsonian Contributions to Zoology, 1-249, doi: 10.5479/si.00810282.627.

Miller, M. A., Pfeiffer, W. \& Schwartz, T. 2010. Creating the CIPRES science gateway for inference of large phylogenetic trees. San Diego Supercomputer Center 9500 Gilman Drive La Jolla CA, 92093-0505, 8.

Mitchell, E. D. 1989. A new cetacean from the late Eocene La Meseta Formation, Seymour Island, Antarctic Peninsula. Canadian Journal of Fisheries and Aquatic Sciences, 46, 22192235, doi: 10.1139/f89-273.

Monciardini, C., Andreieff, P., Blondeau, A., Carbonnel, C., Castaing, J., Châteauneuf, J., Farjanel, G., Lenindre, Y., Marteau, G., Podevin, G., Salin, C., Slansky, M. \& Tchota, K. 1986. Synthèse géologique du bassin côtier Crétacé supérieur-Tertiaire du Togo, recherche de tourbe, lignite, charbon et autres substances industrielles. Rapport 85TGO O56 GEO, BRGM, Orléans (inédit), $111 \mathrm{p}$.

Mourlam, M. J. \& Orliac, M. J. 2017. Infrasonic and ultrasonic hearing evolved after the emergence of modern whales. Current Biology, 27, 1776-1781.e9, doi: 10.1016/j.cub.2017.04.061.

Mourlam, M. J. \& Orliac, M. J. 2018. Protocetid (Cetacea, Artiodactyla) bullae and petrosals from the middle Eocene locality of Kpogamé, Togo: new insights into the early history of 
cetacean hearing. Journal of Systematic Palaeontology, 16, 621-644, doi:

10.1080/14772019.2017.1328378.

Mourlam, M. J. \& Orliac, M. J. 2019. Early evolution of the ossicular chain in Cetacea: Into the middle ear gears of a semi-aquatic protocetid whale. Proceedings of the Royal Society B: Biological Sciences, 286, doi: 10.1098/rspb.2019.1417.

Nummela, S. \& Yamato, M. 2018. Hearing. In Marine Mammal Encyclopedia, (Third Ed., pp 466-467).

Nummela, S., Thewissen, J. G. M., Bajpai, S., Hussain, T. \& Kumar, K. 2007. Sound transmission in archaic and modern whales: anatomical adaptations for underwater hearing. Anatomical Record, 290, 716-733, doi: 10.1002/ar.20528.

Odumodu, C. F. R. \& Nfor, B. N. 2012. A new paratype of an Eocene Nautiloid from the Ameki Formation, Southeastern Nigeria: implications for age and paleoenvironnemental interpretation. Stratigraphy and sedimentology of oil-gas Basins, 2, 3-9.

Onuigbo, E. N., Okoro, A. U. \& Chibuzor, S. 'Nwaife'. 2020. Geochemistry and paleoenvironment of the phosphorites from the Ameki Formation, Niger delta, Nigeria. Global Journal of Geological Sciences, 18, 1-14, doi: 10.4314/gjgs.v18i1.1.

Pascal, M. 1987. Nouvelles découvertes de minéralisations phosphatées au Sénégal: Les gisements de N'Diendouri-Ouali Diala (Département de Matam, région du Fleuve). Chronique de la recherche minière, 3-24.

Ranke, U., Von Rad, U. \& Wissmann, G. 1982. Stratigraphy, facies and tectonic development of the onshore and offshore Aaiun-Tarfaya Basin - a review. Geology of the northwest African continental margin, 86-105.

Reyment, R. A. 1965. Aspect of the geology of Nigeria. The stratigraphy of the Cretaceous and Cenozoic. Ibadan University Press, Nigeria, 145p. 
Safia, M. Al, Radwan, A. N. \& Marwa, A. 2019. A new hiatus within the Lutetian of the El Basatin section, Gebel Mokattam, Egypt: field and sedimentological observations, with special emphasis on Nummulites. Acta Geologica Sinica, 93, 12-29, doi: 10.1111/17556724.13759.

Sallam, E., Issawi, B. \& Osman, R. 2015. Stratigraphy, facies, and depositional environments of the Paleogene sediments in Cairo-Suez district, Egypt. Arabian Journal of Geosciences, 8 , 1939-1964, doi: 10.1007/s12517-014-1360-8.

Samb, M. 2008. Géologie, minéralogie, pétrographie et géochimie minérale des phosphates de Tobène (Sénégal). Application à une exploitation. Université Cheikh Anta Diop (Dakar), 219 p.

Simpson, G. G. 1944. Tempo and mode in evolution. Columbia University. Press, New York.

Slansky. 1962. Contribution à l'étude géologique du bassin sédimentaire côtier du Dahomey et du Togo. Thèse université de Nancy, 335 p.

Slansky. 1980. Géologie des phosphates sédimentaires. Mémoire du BRGM, 114, 93.

Stromer, E. 1908. Die Archaeoceti des Äegyptischen Eokäns. Beiträge zur Paläontologie und Geologie Österreich-Ungarns und des Orients, Wien und Leipzig, 21, 106-178.

Swofford, D. L. 1985. PAUP: Phylogenetic analysis using parsimony. User's manual. Illinois Natural History Survey, Champaign., 72.

Swofford, D. L. 2002. PAUP*. Phylogenetic analysis using parsimony (*and other methods) Version 4.0. Sinauer Associates, Sunderland, Massachusetts, 144.

Swofford, D. L. \& Olsen, G. J. 1990. Phylogeny reconstruction. In: D. M. Hillis and C. Moritz ieds). Molecular Systematics. Sinauer Associates, Sunderland, Massachusetts., 411-501.

Thewissen, J. G. M. \& Bajpai, S. 2009. New skeletal material of Andrewsiphius and Kutchicetus, two Eocene cetaceans from India. Journal of Paleontology, 83, 635-663, doi: 
10.1666/08-045.1.

Thewissen, J. G. M. \& Hussain, S. T. 2000. Attockicetus praecursor, a new remingtonocetid cetacean from marine Eocene sediments of Pakistan. Journal of Mammalian Evolution, 7, 133-146, doi: 10.1023/A:1009458618729.

Thewissen, J. G. M., Cooper, L. N., George, J. C. \& Bajpai, S. 2009. From land to water: the origin of whales, dolphins, and porpoises. Evolution: Education and Outreach, 2, 272-288, doi: 10.1007/s12052-009-0135-2.

Uhen, M. D. 1998. New protocetid (Mammalia, Cetacea) from the late middle Eocene cook mountain Formation of Louisiana. Journal of Vertebrate Paleontology, 18, 664-668, doi: 10.1080/02724634.1998.10011093.

Uhen, M. D. 1999. New species of protocetid archaeocete whale, Eocetus wardii (Mammalia: Cetacea) from the middle Eocene of North Carolina. Journal of Paleontology, 73, 512-528, doi: 10.1017/S002233600002802X.

Uhen, M. D. 2008. New protocetid whales from Alabama and Mississippi, and a new cetacean clade, Pelagiceti. Journal of Vertebrate Paleontology, 28, 589-593, doi: 10.1671/02724634(2008)28[589:NPWFAA]2.0.CO;2.

Uhen, M. D. 2010. The origin (s) of whales. Annual Review of Earth and Planetary Sciences, 38, 189-219, doi: 10.1146/annurev-earth-040809-152453.

Uhen, M. D. 2014. New specimens of Protocetidae (Mammalia, Cetacea) from New Jersey and South Carolina. Journal of Vertebrate Paleontology, 34, 211-219, doi: 10.1080/02724634.2013.784707.

Uhen, M. D., Pyenson, N. D., Devries, T. J., Urbina, M. \& Renne, P. R. 2011. New middle Eocene whales from the Pisco Basin of Peru. Journal of Paleontology, 85, 955-969, doi: $10.1666 / 10-162.1$ 
Vautrin, Q., Lihoreau, F., Sambou, B., Thiam, M., Martin, J. E., Tabuce, R., Adnet, S., Lebrun, R., Charruault, A. L., Sarr, R. \& Hautier, L. 2020. From limb to fin: an Eocene protocetid forelimb from Senegal sheds new light on the early locomotor evolution of cetaceans. Palaeontology, 63, 51-66, doi: https://doi.org/10.5061/dryad.2vr4152.

Visse, L. 1957. Le faciès phosphate togolais. Direction Générale des Mines et de la Géologie, Lomé-Togo, Rapport inédit., 119 p.

Wang, C., Li, X., Hu, X. \& Jansa, L. F. 2002. Latest marine horizon north of Qomolangma (Mt Everest): implications for closure of Tethys seaway and collision tectonics. Terra Nova, 14, 114-120, doi: 10.1046/j.1365-3121.2002.00399.x.

Wible, J. R. 1993. Cranial circulation and relationships of the Colugo Cynocephalus (Dermoptera, Mammalia). American Museum Novitates, 27. 
Table 1. Measurements (in $\mathrm{mm}$ ) for upper tooth crowns of KPO1: canines (C), premolars (P), and molars (M). Estimates are marked with questions marks.

Tableau 1. Mesures (en mm) des couronnes des dents supérieures de KPO1 : canine (C), prémolaires (P) et molaires (M). Les estimations sont marquées d'un point d'interrogation.

\begin{tabular}{llll}
\hline Tooth locus & Length & Width & Height \\
\hline Left $\mathrm{C}$ & 18 & 11.5 & 11.7 \\
Left $\mathrm{P}^{1}$ & $17.7 ?$ & $7.7 ?$ & - \\
Left $\mathrm{P}^{2}$ & 25.8 & 10.1 & 9.4 \\
Right $\mathrm{P}^{2}$ & - & 10.3 & - \\
Left $\mathrm{P}^{3}$ & 27.3 & - & 13.3 \\
Right $\mathrm{P}^{3}$ & 26.4 & - & - \\
Left $\mathrm{P}^{4}$ & 26.4 & 17.1 & 16.1 \\
Right $\mathrm{P}^{4}$ & 26.7 & 17.7 & 15.1 \\
Left $\mathrm{M}^{1}$ & 21.5 & 17.5 & - \\
Right $\mathrm{M}^{1}$ & - & - & - \\
Left $\mathrm{M}^{2}$ & 19.97 & 21.7 & 11.6 \\
Right $\mathrm{M}^{2}$ & 20.5 & - & 10.2 \\
Left $\mathrm{M}^{3}$ & - & - & \\
\hline
\end{tabular}


Table 2. Upper teeth measurements (in $\mathrm{mm}$ ) for selected remingtonocetids and protocetids.

Tableau 2. Mesures des dents supérieures (en mm) pour certains rémingtonocètes et protocètes connus.

\begin{tabular}{|c|c|c|c|c|c|c|c|c|c|c|c|c|c|c|c|c|c|}
\hline & $\mathbf{C}$ & $\mathbf{P}^{1}$ & $\mathbf{P}^{2}$ & $\mathbf{P}^{3}$ & $\mathbf{P}^{4}$ & $\mathbf{M}^{1}$ & $\mathbf{M}^{2}$ & $\mathbf{M}^{3}$ & $\mathbf{C}$ & $\mathbf{P}^{1}$ & $\mathbf{P}^{2}$ & $\mathbf{P}^{3}$ & $\mathbf{P}^{4}$ & $\mathbf{M}^{1}$ & $\mathbf{M}^{2}$ & $\mathbf{M}^{3}$ & References \\
\hline & \multicolumn{8}{|c|}{ Length } & \multicolumn{9}{|c|}{ Width } \\
\hline \multicolumn{18}{|l|}{ Remingtonocetidae } \\
\hline R. harudiensis (IITR-SB 2770)Right & 21 & & 38 & 39 & 28 & 21 & 19 & 18 & 7 & & 5 & 7 & 12 & 12 & 11 & 10 & Bajpai et al.,2011 \\
\hline R. harudiensis (IITR-SB 2770)Left & 19 & 19 & 36 & 39 & 31 & 20 & 19 & & 7 & 5 & 6 & 7 & 11 & 11 & 11 & & Bajpai et al.,2011 \\
\hline R. domandaensis & 20 & 20 & & & & & & & 9.6 & 6.8 & & & & & & & Gingerich et al., 2001 \\
\hline \multicolumn{18}{|l|}{ Protocetidae } \\
\hline \multirow[t]{2}{*}{ Maiacetus inuus Female (Rigth) } & 19.23 & 16.8 & 28.6 & 28.65 & 25.46 & 19.9 & 20 & & & 7.76 & & & & & & & Gingerich et al., 2009 \\
\hline & & 1 & & & & 3 & & & & & & & & & & & \\
\hline Ma. inuиs Female (Left) & 13.21 & & & & & & & & 26 & & & & & & & & Gingerich et al., 2009 \\
\hline \multirow[t]{2}{*}{ Ma. inuus Male (right) } & 23.8 & 16.2 & 29 & 33.79 & 25.57 & 20.2 & 21.39 & 14 & 13.65 & 8.98 & 12.72 & 16.4 & 20.2 & & 17.4 & 12.1 & Gingerich et al., 2009 \\
\hline & & 4 & & & & 1 & & & & & & & 2 & & & 6 & \\
\hline Protocetus atavus SMNS 11084 & 26.5 & 20.9 & 34.2 & 36.4 & 25 & 20 & & 14.2 & 12.3 & 9.8 & 12.1 & 16.8 & 20.3 & & & 13.4 & Hulbert et al., 1998 \\
\hline Dhedacetus hyaeni (Right) & & & 34.1 & & & & 19.5 & 14.4 & & & 11.9 & & & & & & Bajpai and Thewissen, 2 \\
\hline Dh. hyaeni (Left) & & 22.5 & & 33.1 & & 20.7 & 18.6 & & & 10.5 & & 15 & & & & & Bajpai and Thewissen, 2 \\
\hline Kharodacetus sahnii (right) & & 32.7 & 49.4 & 45.7 & 40.1 & 29.5 & & & & 14.8 & 17.9 & 21.1 & & 27.7 & & & Bajpai and Thewissen, 2 \\
\hline K. sahnii (Left) & & & 45.5 & & 39.5 & 31.9 & 27.8 & & & 14.2 & 17.6 & & 33.7 & & 26.3 & & Bajpai and Thewissen, 20 \\
\hline
\end{tabular}


Indocetus ramani IITR/SB/2986

I. ramani LUVP 11034

I. ramani $\mathrm{IITR} / \mathrm{SB} / 4001$

Togocetus traversei

Georgiacetus vogtlensis

Tupelocetus palmeri ChM PV6950

Aegicetus gehennae

KPO1 Left

KPO1 Right
20.6

40.0

37.0

33.3

23.0

25.2

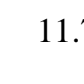

$$
\begin{array}{lll}
34.4 & 29.8 \quad 22.3
\end{array}
$$

21.5

$33.4 \quad 28.5 \quad 23.4$

$27.0 \quad 39.0$

29

18
27.7

2.140.

44

43.58

$\begin{array}{llll}27 & 39 & 49\end{array}$

$17.7 ? \quad 25.8$
$42 \quad 40$

$27.3 \quad 26.4$

$26.4 \quad 26.7$
23.4

$$
25.5
$$

26.3

21.5

20.8

17.6

12

16.50

$25.3 \quad 26.3$

$21.5 \quad 19.97$

20.5
20.3

13.3

23.9

22.3

21.8

$17.9 \quad 22.2 \quad 20.9$

$\begin{array}{llllllll}21.5 & 14.4 * & 15.7 & 15.2 * & 25.2 & 26.3 & 24.5 & 25\end{array}$

$17.1 \quad 17.5 \quad 21.7$

17.7

Bianucci and Gingerich,

Bajpai and Thewissen, 20

Bajpai and Thewissen, 20

Bajpai and Thewissen, 20

Gingerich \& Cappetta, 20

18.5 Hulbert et al., 1998

Gibson et al., 2019

16.8 Gingerich et al., 2019

Kassegne et al. this study

Kassegne et al. this study 
Table 3. Supports for the different nodes of the strict consensus (Figure 7; $\mathrm{L}=691 ; \mathrm{CI}=0.47 ; \mathrm{RI}=0.67$ ) of the 2,100 most parsimonious trees ( $\mathrm{L}$ $=674 ; \mathrm{CI}=0.49 ; \mathrm{RI}=0.68)$ under ACCTRAN optimisation. Characters in bold indicate convergences. Character's list available in Supplemental Text 2.

Tableau 3. Supports des différents nœuds du consensus strict (Figure 7 ; L = 691; CI =0.47; RI =0.67) de 2100 arbres les plus parcimonieux ( $\mathrm{L}$ $=674 ; \mathrm{CI}=0.49 ; \mathrm{RI}=0.68)$. Les caractères en gras indiquent les convergences. La liste des caractères est disponible en anglais dans les annexes (Supplemental Text 2)

\begin{tabular}{|c|c|c|c|c|c|}
\hline \multirow[t]{3}{*}{ Clade Name } & \multirow[t]{3}{*}{ Node } & \multirow{3}{*}{$\begin{array}{l}\text { Bremer sup- } \\
\text { port }\end{array}$} & \multirow{3}{*}{$\begin{array}{l}\text { Number of } \\
\text { Synapomorphies }\end{array}$} & \multirow{3}{*}{$\begin{array}{l}\text { Number of } \\
\text { non-ambiguous } \\
\text { Synapomorphies }\end{array}$} & \multirow{3}{*}{$\begin{array}{l}\text { Non-ambiguous Synapomorphies - } \\
\text { Character (state) }\end{array}$} \\
\hline & & & & & \\
\hline & & & & & \\
\hline \multirow[t]{4}{*}{ Cetacea } & $\mathrm{C}$ & 2 & 18 & 11 & $32(2), 35(1), 45(1), 47(2), 49(0), 62(1), 63(1)$, \\
\hline & & & & & $\mathbf{8 7}(\mathbf{3}), 96(0), 138(0), \mathbf{1 6 1}(\mathbf{0})$ \\
\hline & $\mathrm{C} 1$ & 1 & 24 & 4 & $118(1), 153(1), \mathbf{1 5 5}(\mathbf{1}), 158(1)$ \\
\hline & $\mathrm{C} 2$ & 1 & 11 & 4 & $55(1), 59(2), 98(1), 156(1)$ \\
\hline Remingtonocetidae & $\mathrm{R}$ & 1 & 17 & 2 & $6(2), 20(0)$ \\
\hline
\end{tabular}




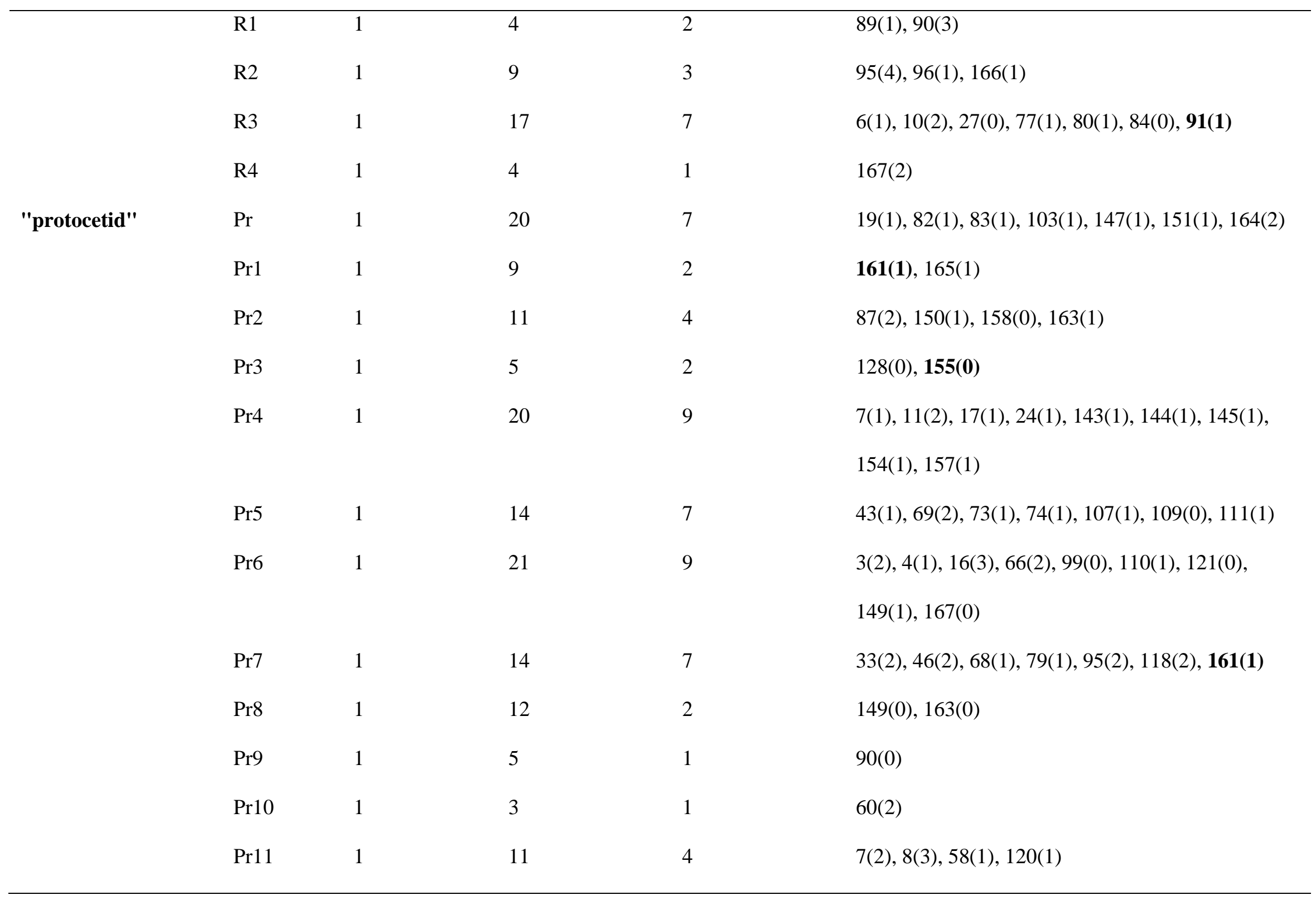


Pr12

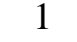

24

8

17(0), 34(0), 64(1), 71(0), 76(1), 104(2), 155(0),

159(0)

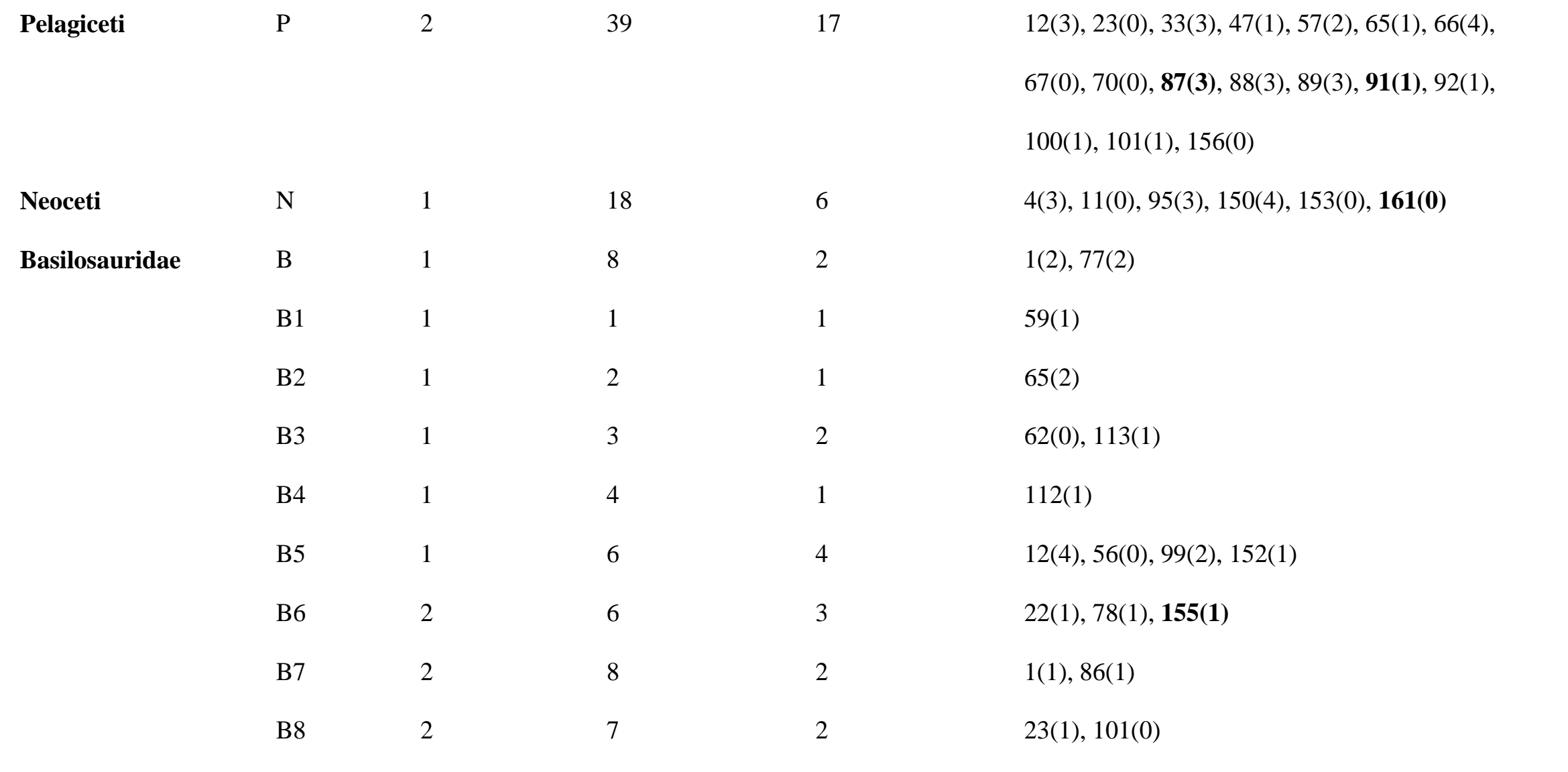




\section{Figure legend}

Figure 1. Map (A) showing the geographic and geologic position of Kpogamé quarry that yielded the cranium KPO1 and stratigraphic position (B) described in this study. The black star indicates the area where the first remains of Togocetus traversei were discovered (Gingerich \& Cappetta, 2014), the red star indicates the position of KPO1 in Kpogamé quarry. C, photo showing the fossil of KPO1 in phosphate carbonate deposit from the base of the sequence (B). 1- palygorskite-rich claystone, 2phosphatic marl, 3- calcareous phosphate, 4- phospharenite, 5- oxidized phosphate, 6- clay, 7- gravel, sand, silt.

Figure 1. Carte montrant la position géographique et géologique (A) et la position stratigraphique (B) de la carrière de Kpogamé. L'étoile noire indique la zone où les premiers restes de Togocetus traversei ont été découverts (Gingerich \& Cappetta, 2014) et l'étoile rouge la position de KPO1 dans la carrière de Kpogamé. C, photo montrant le fossile KPO1 dans le dépôt de phosphates carbonatés situé à la base de la séquence (B). 1- argilite feuilletée à attapulgite, 2- marne phosphatée, 3- phosphate carbonaté, 4phospharénite, 5- phosphate oxydé, 6- argile, 7- gravier, sable, silt.

Figure 2. Dorsal view of the cranium KPO1. Dotted areas represent broken parts. Abbreviations, ant, anterior; C, canine; $\mathrm{M}^{2}$, second upper molar; Nas, nasal; $\mathrm{P}^{4}$, fourth upper premolar; Sq, squamosal; Vo, vomer; zp, zygomatic process of the squamosal. Scale bar represents $5 \mathrm{~cm}$.

Figure 2. Vue dorsale du crâne KPO1. En pointillé, les parties cassées ou fracturés. Abréviations : ant, antérieur ; $\mathrm{C}$, canine ; $\mathrm{M}^{2}$, deuxième molaire supérieure ; Nas, nasal; $\mathrm{P}^{4}$, quatrième prémolaire 
supérieure; Sq, squamosal Vo, vomer; zp, processus zygomatique du squamosal. La barre d'échelle représente $5 \mathrm{~cm}$.

Figure 3. Palatal view of the cranium KPO1. Embrasure pits are represented by hatched areas. The suture between the maxillae and the palatines (dotted line) was identified based on $\mu \mathrm{CT}$ data. Abbreviations: C, canine; eam, external auditory meatus; fo, foramen ovale; gr, maxillar groove; M, molar; Max, maxilla; P, premolar; Pal, palatine; pc, palatal crest; pgp, postglenoid process; Sq, squamosal; zp, zygomatic process of the squamosal. Scale bar represents $5 \mathrm{~cm}$.

Figure 3. Vue palatine du crâne KPO1. Les fosses d'embrasure sont représentées par des zones hachurées. La suture entre les maxillaires et les palatins (trait pointillé) a été reconstruite à partir de données $\mu \mathrm{CT}$. Abréviations : C, canine ; eam, méat auditif externe ; fo, foramen ovale ; gr, sillon maxillaire ; M, molaire ; Max, maxillaire ; P, prémolaire ; Pal, palatin ; pc, crête palatine ; pgp, process post-glénoïde ; Sq, squamosal ; zp, processus zygomatique du squamosal. La barre d'échelle représente $5 \mathrm{~cm}$.

Figure 4. Ventral (A) and medial (B) views of the basicranium of KPO1. (C) Comparison (not to scale) between the entoglenoid process of KPO1, and that of the morphotype $\gamma$ from Kpogamé and that of the protocetid Georgiacetus (GSM 350; inverted image) in order to highlight (1) the peculiar hat shape entoglenoid process (i.e. sub-rectangular; character $46^{3}$ ) and (2) the main differences between the morphotype $\gamma$ and KPO1 such as the shape of the posterolateral rim (red line) and the size of the vascular groove (vg). Abbreviations: bh, bony hook; brb, broad bowl-shaped recess (see description); brs, small bowl-shaped recess; cap, contact surface with the anterior process of the tegmen tympani of 
the petrosal; cevf, capsuloparietal emissary vein foramen; eam, external auditory meatus; egp, entoglenoid process; et, Eustachian tube; fo, foramen ovale; gf, glenoid fossa; pgf, postglenoid foramen; pgp, postglenoid process; pmp, postmeatal process; pms, "postmeatal sulcus"; sbc, shallow bony channel; sef, squamosal emissary foramen; spc, contact site on the squamosal for the sigmoid process of the ectotympanic; sse, sutural surface for the posterior process of the ectotympanic; ssp, sutural surface for the posterior process of the petrosal; vg, vascular groove; zp, zygomatic process of the squamosal. Scale bar represents $5 \mathrm{~cm}$.

Figure 4. Vue ventrale (A) et médiale (B) du basicrâne de KPO1. (C) Comparaison (pas à l'échelle) entre le processus entoglénoïde de KPO1, celui du morphotype $\gamma$ de Kpogamé et celui du protocète Georgiacetus (GSM 350; image inversée) afin d'illustrer (1) la particularité d'un processus entoglénoïde en forme de chapeau (i.e. sub-rectangulaire ; caractère $46^{3}$ ) ainsi que (2) les différences notables entre le morphotype $\gamma$ et KPO1 telles que la forme du bord postero-latéral (ligne rouge) et la taille du sillon vasculaire (vg). Abréviations : bh, crochet osseux ; brb, large alcôve en forme de bol (voir description) ; brs, petite alcôve en forme de bol ; cap, surface de contact avec le processus antérieur du tegmen tympani du pétreux ; cevf, foramen de la veine émissaire capsulopariétale ; eam, méat auditif externe; egp, processus entoglénoïde ; et, trompe d'Eustache ; fo, foramen ovale ; gf, fosse glénoïde ; pgf, foramen post-glénoïde ; pgp, processus post-glénoïde ; pmp, processus post-méatal ; pms, "sulcus postméatal" ; sbc, canal osseux peu profond ; sef, foramen émissaire squamosal ; spc, zone de contact sur le squamosal pour le processus sigmoïde de l'ectotympanique ; sse, surface de suture pour le processus postérieur de l'ectotympanique ; ssp, surface de suture pour le processus postérieur du pétreux ; vg, sillon vasculaire; zp, processus zygomatique du squamosal. La barre d'échelle représente $5 \mathrm{~cm}$. 
Figure 5. 3D reconstructions of the cranium and teeth of KPO1. A, B, and C, lateral view of the left side of KPO1; D, lingual view; E, occlusal view. The doubled arrows indicate the duplicated apex of the root of the canine (see description). Abbreviations: C, canine; iof, infraorbital foramen; M, molar; P, premolar. The cranium elements are in grey, canine in dark red, premolar in light red and molar in yellow. Scale bar represents $2 \mathrm{~cm}$.

Figure 5. Reconstructions 3D du crâne et des dents de KPO1. A, B et C, vue latérale du côté gauche de KPO1 ; D, vue linguale ; E, vue occlusale. Les flèches doubles indiquent l'extrémité dédoublée de la racine de la canine. Abréviations : C, canine ; iof, foramen infraorbitaire; M, molaire ; $\mathrm{P}$, prémolaire. Les éléments du crâne sont ici représentés en gris, la canine en rouge foncé, les prémolaires en rouge clair et les molaires en jaune. Les barres d'échelle représentent $2 \mathrm{~cm}$.

Figure 6. Comparisons between $3 \mathrm{D}$ reconstructions of $\mathrm{KPO} 1$ teeth $(\mathrm{A}, \mathrm{C}, \mathrm{E}, \mathrm{G}, \mathrm{I}, \mathrm{K}$, and $\mathrm{M})$ and isolated teeth of Togocetus traversei (B, D, F, H, J, L, N, and O; Gingerich \& Cappetta, 2014): A, buccal view of the left $\mathrm{P}^{1}$ of KPO1; $\mathrm{B}$, buccal view of the left $\mathrm{P}^{1}$ of KPG-M9; C, buccal view of the left $\mathrm{P}^{3}$ of KPO1; D, buccal view of the left $\mathrm{P}^{3}$ of KPG-M39; E-G, buccal and lingual views of the left $\mathrm{P}^{4}$ of KPO1; F-H, buccal and lingual views of the left $\mathrm{P}^{4}$ of KPG-M134; I-K-M, lingual, occlusal, and mesial views of the left $\mathrm{M}^{2}$ of KPO1; J-L-N, lingual, occlusal, and mesial views of the right $\mathrm{M}^{2}$ of KPG-M4 (images inverted); O, mesial view of the right $\mathrm{M}^{2}$ KPG-M6 (image inverted). Abbreviations: gr, lingual groove suggestive of the presence of a metacone; m, metacone; pp, doubled preparacrista. Scale bars represent $1 \mathrm{~cm}$. 
Figure 6. Comparaisons entre des reconstructions 3D de dents de KPO1 (A, C, E, G, I, K et M) et des dents isolées de Togocetus traversei (B, D, F, H, J, L, N et O ; Gingerich \& Cappetta, 2014) : A, $\mathrm{P}^{1}$ gauche de KPO1 en vue buccale; $\mathrm{B}, \mathrm{P}^{1}$ gauche de KPG-M9 en vue buccale; $\mathrm{C}, \mathrm{P}^{3}$ gauche de KPO1 en vue buccale ; D, vue buccale du $\mathrm{P}^{3}$ gauche de KPG-M39; E-G, vues buccale et linguale du $\mathrm{P}^{4}$ gauche de KPO1 ; F-H, vues buccale et linguale du $\mathrm{P}^{4}$ gauche de KPG-M134 ; I-K-M, vues linguale, occlusale et mésiale de la $\mathrm{M}^{2}$ gauche de KPO1 ; J-L-N, vues linguale, occlusale et mésiale de la $\mathrm{M}^{2}$ droite de KPGM4 (images inversées); O, vue mésiale de la $\mathrm{M}^{2}$ droite de KPG-M6 (image inversée). Abréviations : gr, sillon lingual suggérant la présence d'une métacone ; m, métacone ; pp, préparacrista doublée. Les barres d'échelle représentent $1 \mathrm{~cm}$.

Figure 7. Phylogenetic tree of basal cetaceans based on the cladistic analysis of 45 taxa and 167 morphological characters, highlighting the phylogenetic relationships of the KPO1 (red), Togocetus (orange), and the other protocetids taxa from Togo (orange). Topology of the strict consensus $(\mathrm{L}=691$; $\mathrm{CI}=0.47 ; \mathrm{RI}=0.67)$ of the 2,100 most parsimonious trees $(\mathrm{L}=674 ; \mathrm{CI}=0.49 ; \mathrm{RI}=0.68)$. The designation $\mathrm{C}$ indicates the Cetacea, $\mathrm{R}$ the remingtonocetes, $\mathrm{Pr}$ is the paraphyletic assemblage of protocetids and pelagicetes, $\mathrm{P}$ the Pelagiceti, $\mathrm{B}$ the basilosaurids, and $\mathrm{N}$ the Neoceti (see details in Table 3). Supports of the different nodes are indicated in detail in Table 3. Illustrations by R. Mourlam.

Figure 7. Arbre phylogénétique des cétacés basaux issu de l'analyse cladistique de 45 taxons et 167 caractères morphologiques, mettant en évidence les relations phylogénétiques de KPO1 (rouge), Togocetus (orange), et d'autre protocètes du Togo (orange). Topologie du consensus strict (L = 691; CI $=0.47 ; \mathrm{RI}=0.67)$ de 2100 arbres les plus parcimonieux $(\mathrm{L}=674 ; \mathrm{CI}=0.49 ; \mathrm{RI}=0.68)$. La lettre $\mathrm{C}$ désigne le clade Cetacea, $\mathrm{R}$ les remingtonocètes, Pr l'assemblage paraphylétique des protocètes et 
pelagicètes, $\mathrm{P}$ les pélagicètes, et $\mathrm{N}$ les néocètes (voir détails dans le Tableau 3). Les supports aux nœuds sont détaillés dans le Tableau 3. Illustrations faites par R. Mourlam. 


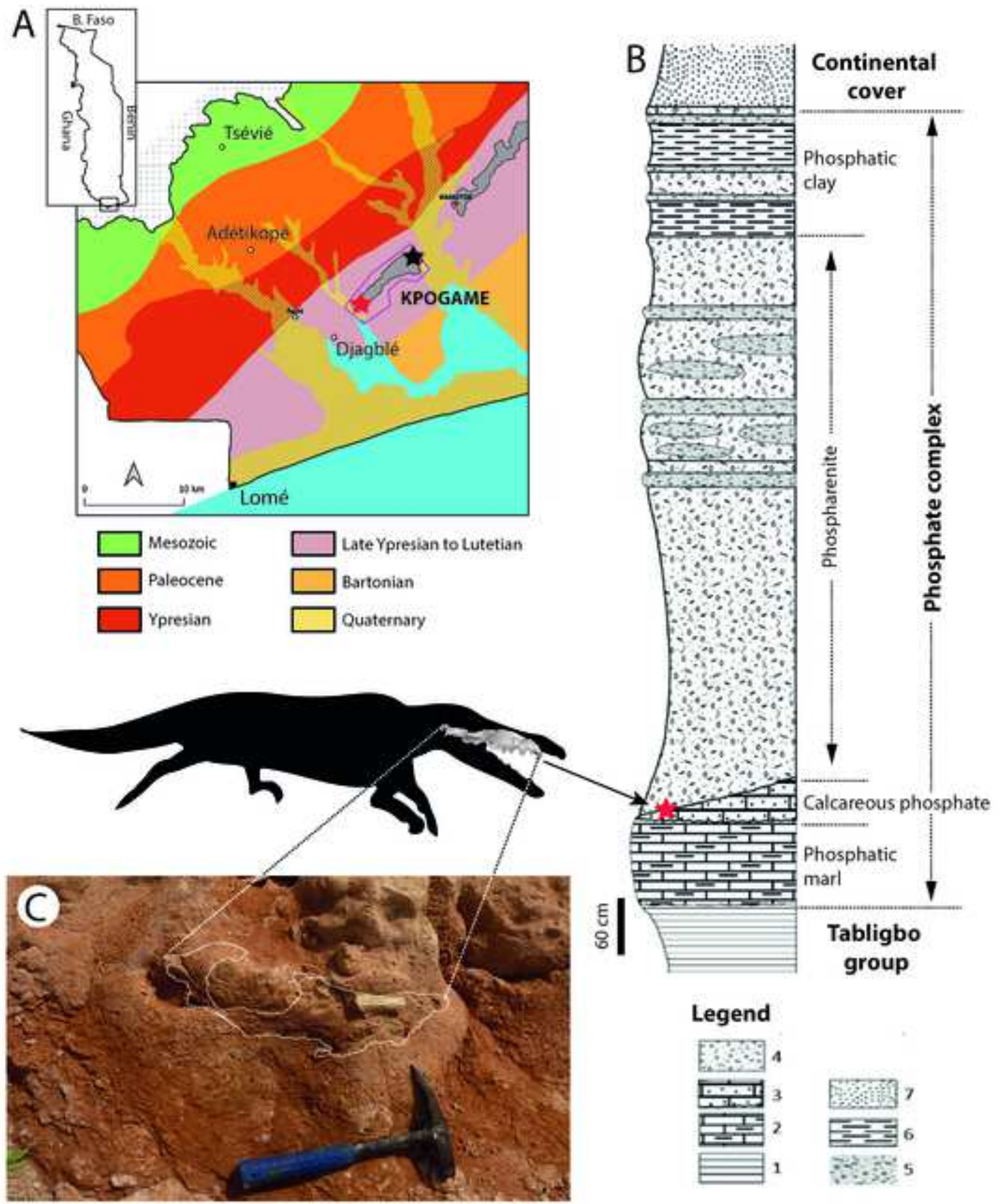



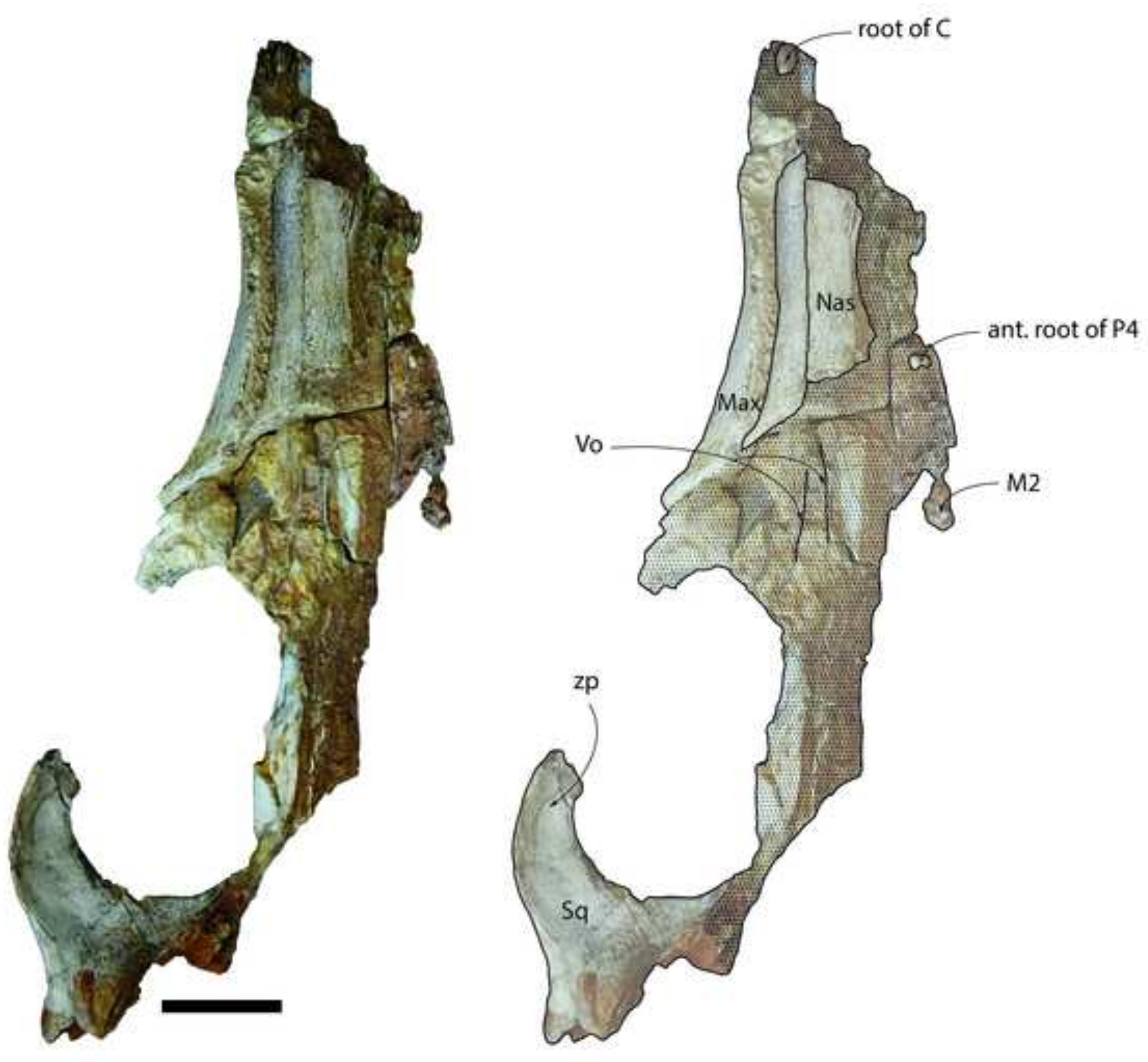

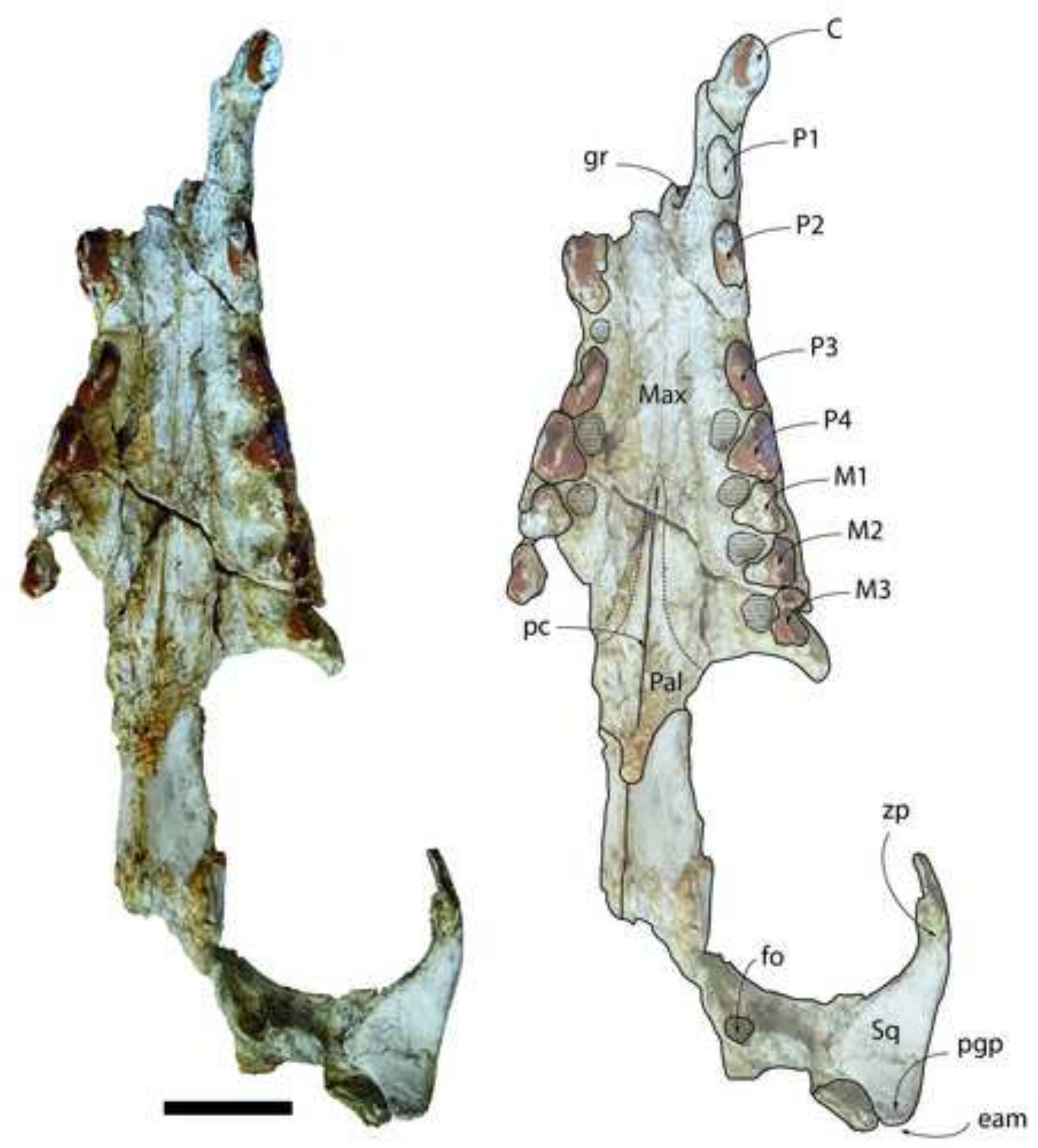
A

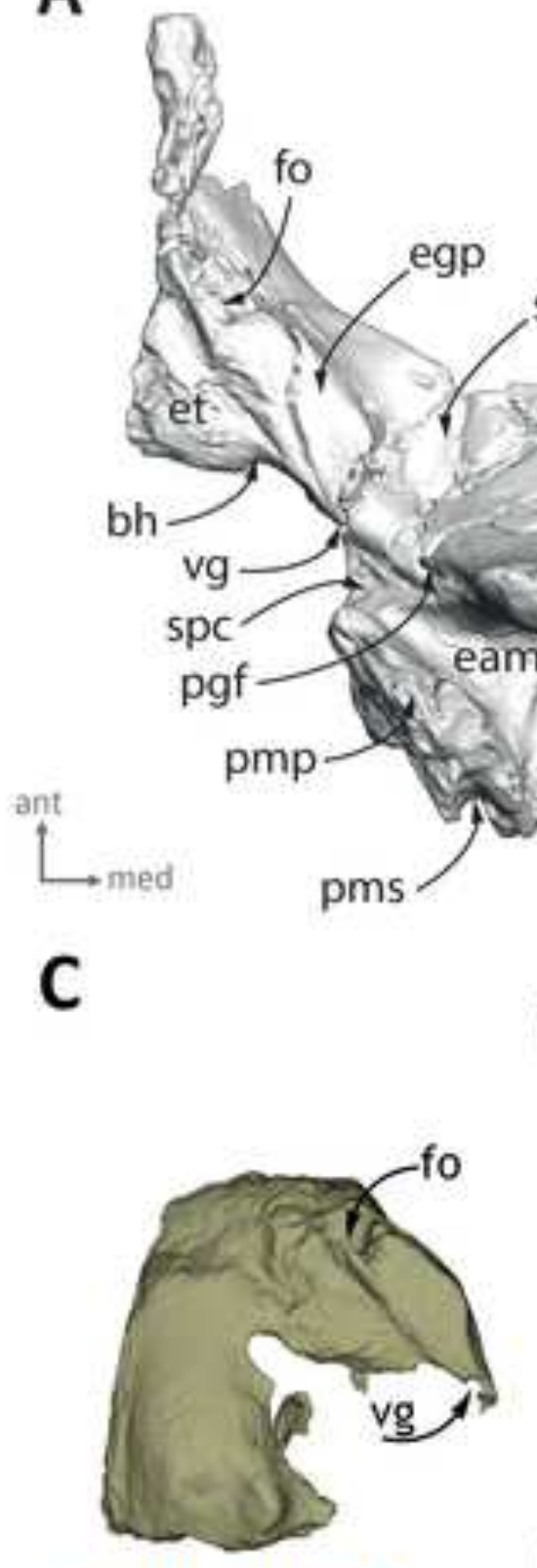

morphotype $\gamma$
(UM-KPG-M 73)

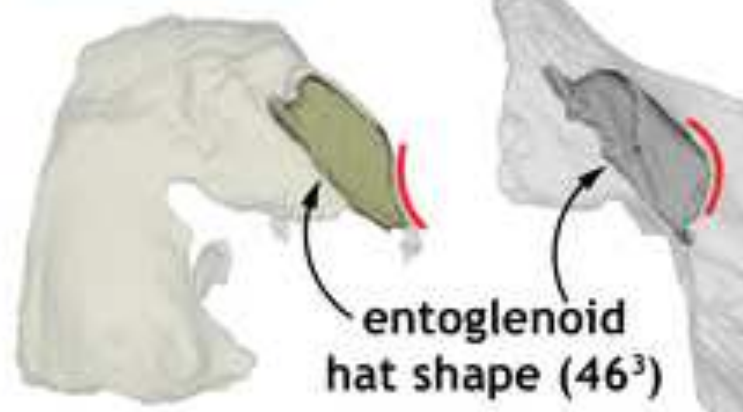

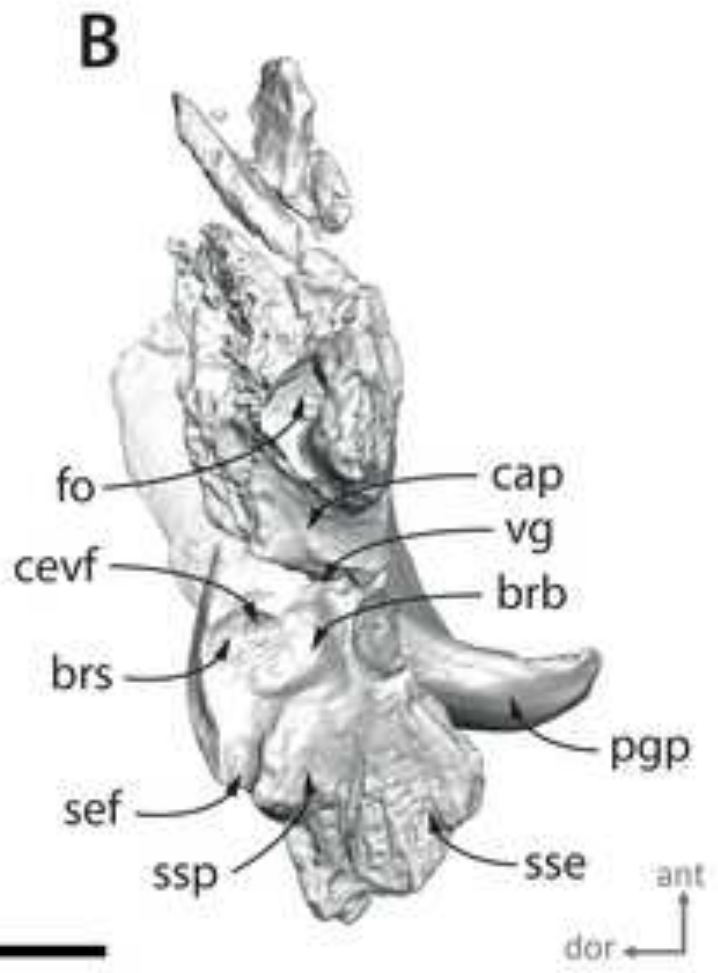

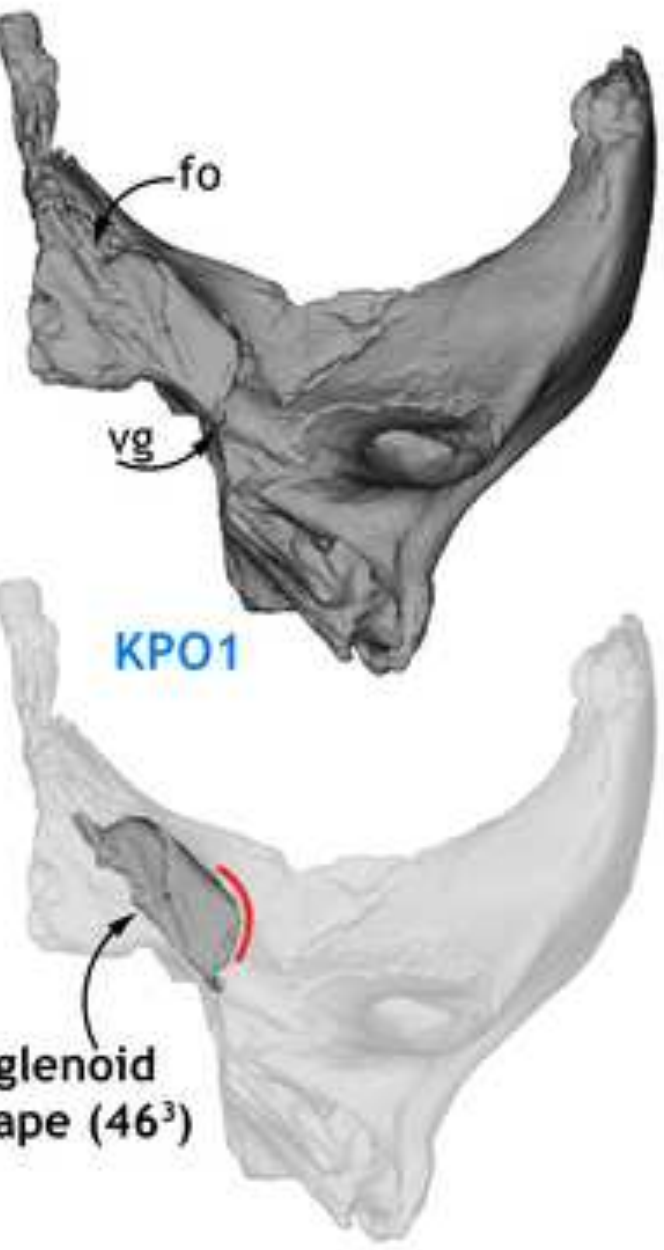

Georgiacetus

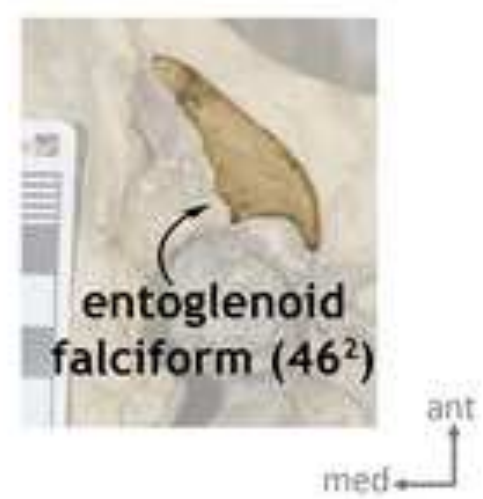



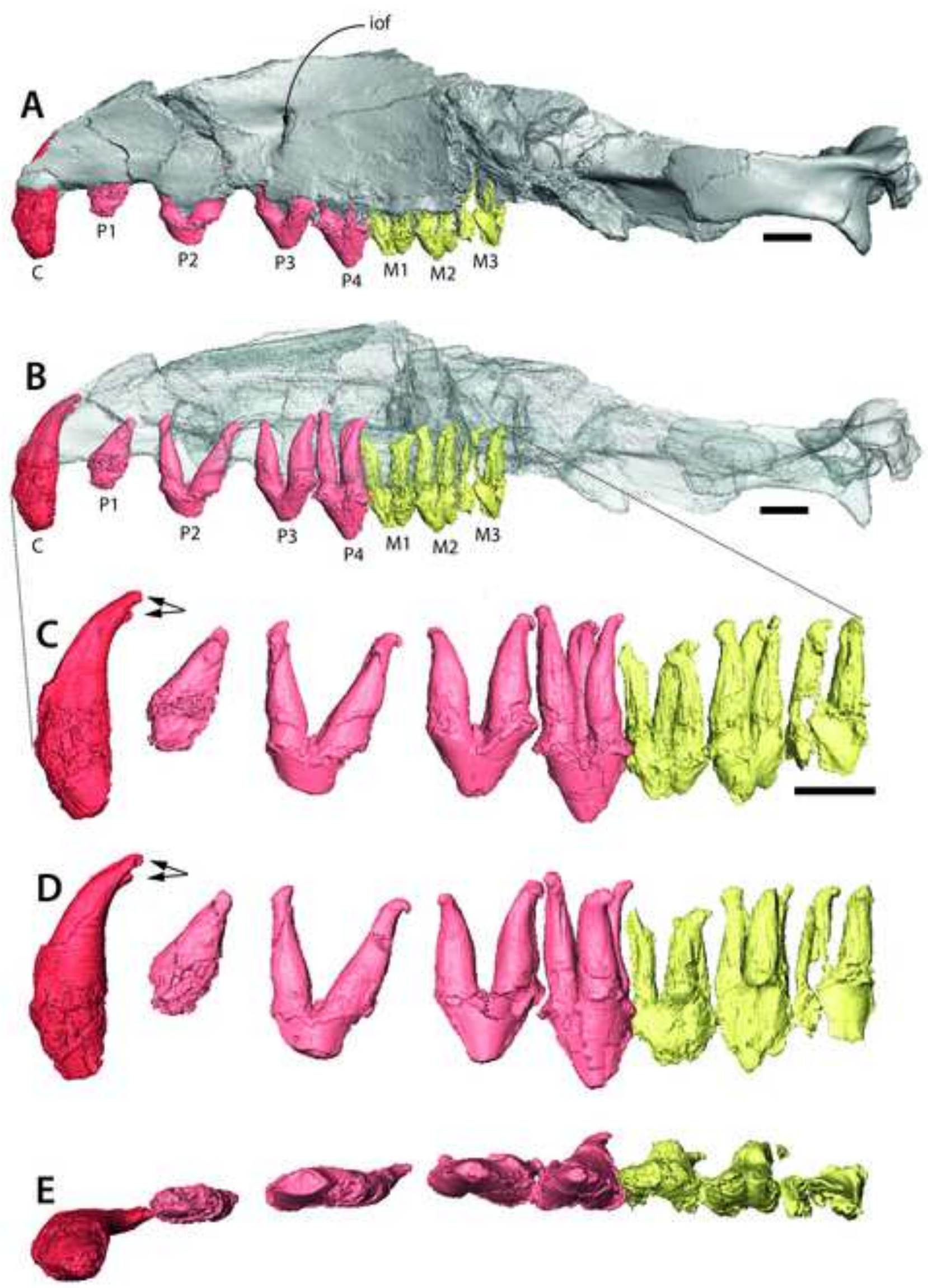


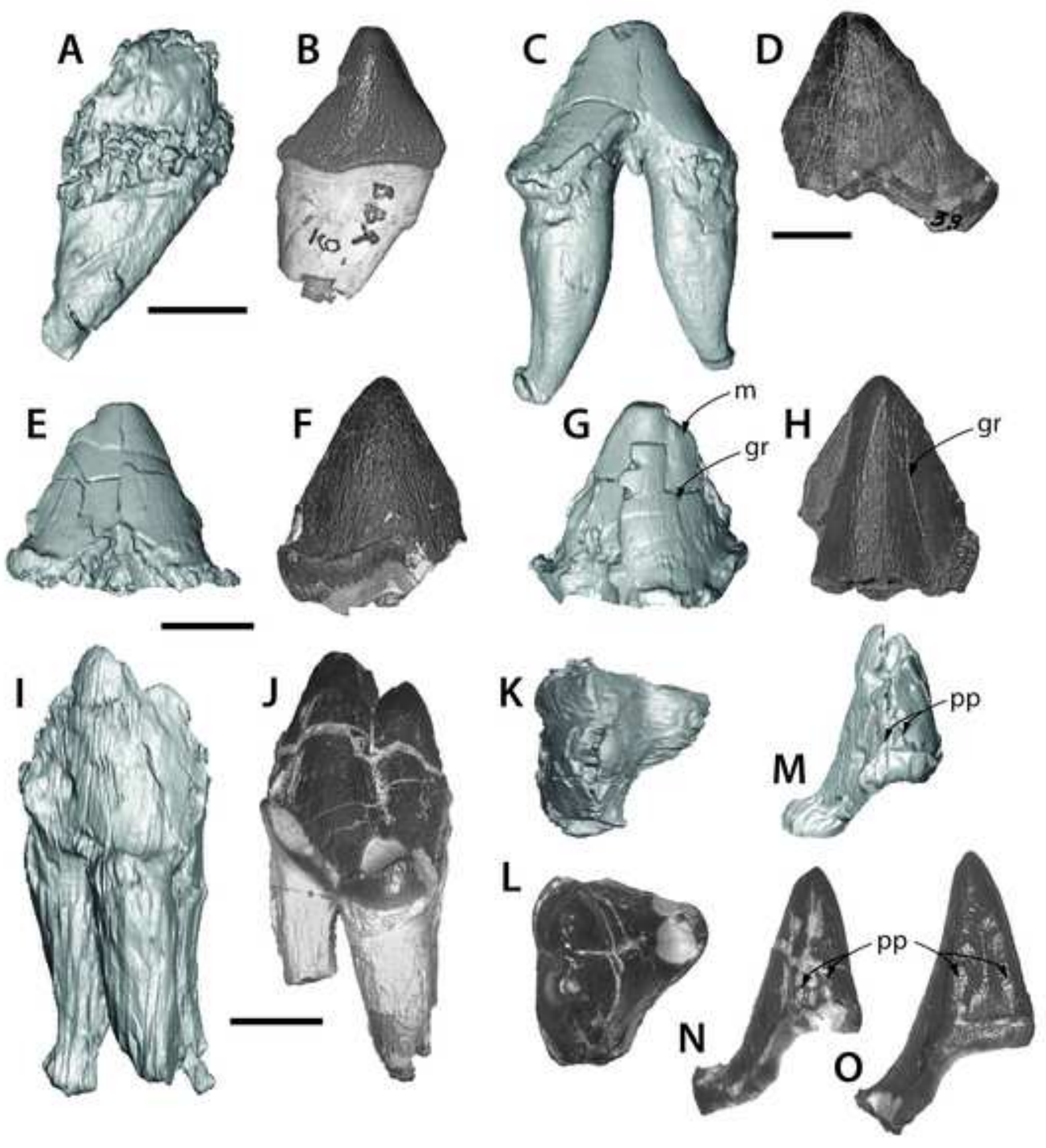




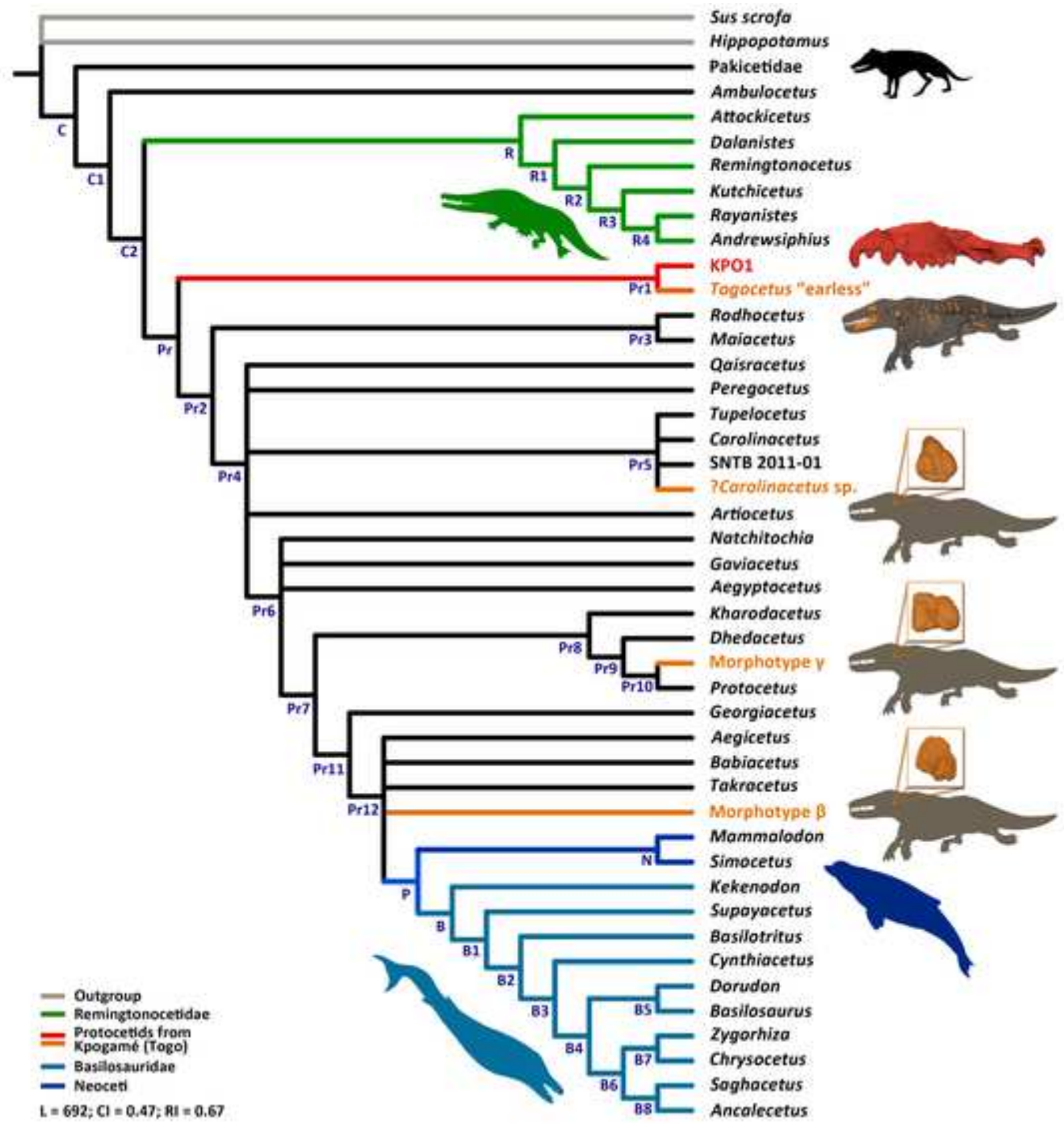


Online Supplementary Material related to First partial cranium of Togocetus from Kpogamé (Togo) and the protocetid diversity in the Togolese phosphate basin.

Premier crâne partiel de Togocetus de Kpogamé (Togo) et la diversité des protocètes dans le bassin phosphaté togolais

Koffi Evenyon KASSEGNE, Mickaël J. MOURLAM, Guillaume GUINOT, Yawovi Zikpi AMOUDJI, Jeremy E. MARTIN, Kodjo Adika TOGBE, Ampah Kodjo JOHNSON, and Lionel HAUTIER

\section{Content}

Text 1. Phylogenetic analysis - Character modifications 02

Text 2. Phylogenetic analysis - Character's list 08

Figure 1. Postglenoid foramen vs. vascular groove 32

Figure 2. Entoglenoid process of morphotype $\gamma$

Figure 3. Strict consensus - Similarity index 34

Figure 4. Strict consensus - without Togocetus "earless" 36

Figure 5. Strict consensus - Togocetus "earless" hypothesis 37

Figure 6. Strict consensus - $\alpha$ hypothesis 38

Figure 7. Strict consensus - $\beta$ hypothesis $\quad 39$

Figure 8. Strict consensus $-\gamma$ hypothesis $\quad 40$

Table 1. Shared and Similarity indexes $\quad 41$ 
Text 1. Phylogenetic analysis - Character modifications

In order to take into account our morphological observations about protocetids (and other archaeocetes), and to highlight their anatomical diversity, we have been led to modify 15 phylogenetic characters from the literature (e.g. Geisler et al. 2005; Gol'din \& Zvonok 2013). The following text aims to shed light on what motivated our choices.

\section{CRANIAL}

\section{Rostrum length:}

This character was initially defined by Thewissen \& Hussain (2000: character 08) in order to compare the length of the rostrum of remingtonocetids. However, since the remingtonocetid present a rather elongated rostrum, the two states of character defined by these authors do not cover the whole spectrum of variability at the scale of archaeocetes and early neocetes:

2. anterior to orbit approximately two times the length of skull posterior to orbit

3. anterior to orbit approximately three times the length of skull posterior to orbit

Thus, we have completed this character by adding the following two states:

0. anterior to orbit equal or smaller than the length of skull posterior to orbit (see Mammalodon)

1. anterior to orbit approximately 1.5 times the length of skull posterior to orbit (most of the known protocetids)

\section{9-10. Embrasure pits between I1-I2 and I2-I3 and C-I3:}

These two characters were initially defined by Geisler et al. (2005: characters 09 and 10) in order to document the presence or not of embrasure pits (and their depth in character 10). Following Thewissen \& Bajpai (2009), we considered also the location of these embrasure pits (i.e. lateral position or not). 


\section{Orbit size:}

The two first states of this character were initially defined by Uhen (1998: character 07). In order to highlight the unusual size of the orbit of Takracetus and some basilosaurids, we completed this character by introducing a new threshold at $60 \%$ of condylar breadth, leading to the modification and the split of the second state as follows:

1. medium, vertical diameter of orbit between $30 \%$ and $60 \%$ of condylar breadth

2. large, vertical diameter of orbit $>60 \%$ of condylar breadth

\section{0-31. Palate angulation and frontal angulation (ex-clinorhynchy):}

The clinorhynchy is the "downward deflection of the rostrum and frontal shield relative to the braincases as a whole" (Bianucci \& Gingerich 2011: 1183). In other words, it is the combination of a relative palate angulation $\left(\theta_{1}\right)$ and relative frontal angulation $\left(\theta_{2}-\theta_{3}\right)$ that are both positives. The character 108 from Bianucci \& Gingerich (2011) only considers two states: the presence or not of clinorhynchy. Thus, several different categories are represented within the absence of clinorhynchy with for instance the taxa with a positive palate angulation and a negative frontal angulation (e.g. Qaisracetus) or the taxa with both negative palate and frontal angulations (e.g. Georgiacetus). To highlight this diversity, we split this character into two new ones, documenting all the cases observed: 30. Palate angulation - 31. Frontal angulation.

\section{Remark on the postglenoid foramen:}

According to Geisler \& Luo (1998: see also Luo \& Gingerich 1999; Martínez-Cáceres et al. 2017), the postglenoid foramen of protocetid is located at the interface between the petrosal and the squamosal. However, KPO1 presents both a distinct postglenoid foramen medial to the postglenoid process and a distinct foramen at the interface between the petrosal and the squamosal (see vascular foramen in Description, Fig.4,

and Supplemental Fig. 1). Consequently, the vascular foramen is not necessary linked to the passage of the capsuloparietal emissary vein, thus leaving open two conflicting hypotheses: either the postglenoid foramen merges with the vascular foramen later in the evolutionary history of the group, or both foramina are clearly distinct and the postglenoid foramen disappears later within protocetids. While the relationship between this two foramina remains unclear, we have chosen not to use this character 
(Geisler et al. 2005: character 26; modified from Geisler \& Luo 1998: character 24) in our analysis.

\section{AUDITORY REGION}

\section{5-46. Entoglenoid process:}

This character was initially defined by Geisler et al. (2005: character 60) and then modified by Gol'din \& Zvonok (2013: character 33). In their definitions, there is a mix of "presence-absence", "shape" and "contact or not with the tympanic bulla" states. Thus, we decided to bisect this character into a "presence-absence" character (45. Entoglenoid process) and a "shape" character (46. Entoglenoid process shape). Since the tympanic bulla is not always available, we decided to not define a third character about the possible contact with this bone. In addition, based on our observation, we defined 3 new states for the shape character:

1. drop shape, which is an incipient "falciform" with a small lateral lip, as found in Carolinacetus and Tupelocetus

2. falciform, as found in Protocetus and Georgiacetus

3. sub-rectangular, as found in KPO1

\section{Base of posterior process of tympanic:}

This character was defined by Geisler et al. (2005: character 59) and included two states: "0. forms a single columnar pedicle - 1. perforated and forms medial and lateral pedicles". Then, Gol'din \& Zvonok (2013: character 32) added a third state for this character: "2. long and gracile pedicle" to highlight the particularities of neocetes' tympanic bullae. However, the state of preservation of the tympanic bullae of the two neocetes from the taxonomic sample of the present study do not allow to observe this third state and we therefore deleted it.

\section{DENTAL}

\section{I2 length:}

This character was initially defined by Geisler et al. (2005: character 65). It included two states ("O. substantially smaller than canine - 1. subequal to canine") without doing any distinction between upper and lower incisors nor between the different loci. However, for some taxa (e.g. Qaisracetus; see Gingerich et al. 2001), depending on the locus, the incisor can be both shorter and longer than the canine. To avoid this 
issue, we decided to focus the comparison only on the upper $\mathrm{I}^{2}$. In addition, we defined a new state based on the protocetid Qaisracetus: "2. longer than canine".

\section{7-90. Protocone:}

Initially, only two characters were defined concerning the protocone: one about the premolars (Gol'din \& Zvonok 2013: character 43) and one about the molars (Geisler et al. 2005: character 75). Based on our observation, there is morphological variation of the protocone between $\mathrm{P}^{3}$ and $\mathrm{P}^{4}$, and also between $\mathrm{M}^{1}$ and $\mathrm{M}^{2}$. Consequently, we decided to define four distinct characters (one for each of these loci) in order to highlight this diversity. In addition, based on Gingerich et al. (1995) and Thewissen \& Bajpai (2009), we introduced a fourth state of character: "protocone lobe".

\section{1-93. Upper molars' roots:}

Three characters concerning the roots of the upper molars were defined by Uhen (1998: characters 29-31) and then later modified by Geisler et al. (2005: characters 7677 and 79). In their definitions, these authors took in consideration the level of fusion of the roots. However, the level of root's fusion is rather plastic intraspecifically in human and in other mammals (e.g. Peiris et al. 2015; Ahmed et al. 2017; MarcanoCaldera et al. 2019). While there is no study on that matter about early whales, we decided not to take into account the level of fusion of the roots and to focus on their numbers only ("0. three roots - 1 . two roots").

\section{VERTEBRAL, STERNAL AND RIB}

\section{Number of lumbar vertebrae:}

Based on the observations made by Gingerich et al. (2019) on Aegicetus, we defined a new state to the character 59 of Gol'din \& Zvonok (2013) modified from Geisler et al. (2005: character 90; see also Uhen 1998 and Martínez-Cáceres \& Muizon 2011): "0. 4 lumbar vertebrae".

\section{PECTORAL AND FORELIMB}

\section{Humerus capitulum:}

Based on our observations on Andrewsiphius and Kutchicetus (Thewissen \& Bajpai 2009: fig. 10), we defined a new state to the character 99 of Vautrin et al. (2020):

"1. incipient (narrow and flat)". 


\section{References}

Ahmed, H. M. A., Versiani, M. A., De-Deus, G. \& Dummer, P. M. H. 2017. A new system for classifying root and root canal morphology. International Endodontic Journal, 50, 761-770, doi: 10.1111/iej.12685.

Bianucci, G. \& Gingerich, P. D. 2011. Aegyptocetus tarfa, n. gen. et sp. (Mammalia, Cetacea), from the middle Eocene of Egypt: Clynorhynchy, olfaction, and hearing in protocetid whale. Journal of Vertebrate Paleontology, 31, 1173-1188.

Geisler, J. H. \& Luo, Z.-X. 1998. Relationships of Cetacea to Terrestrial Ungulates and the Evolution of Cranial Vasculature in Cete. In: Thewissen, J. G. M. (ed.) The Emergence of Whales. Plenum Press, New York and London, 163-212.

Geisler, J. H., Sanders, A. E. \& Luo, Z.-X. 2005. A New Protocetid Whale (Cetacea: Archaeoceti) from the Late Middle Eocene of South Carolina. American Museum Novitates, 3480, 1-65, doi: 10.1206/0003-0082(2005)480[0001:ANPWCA]2.0.CO;2.

Gingerich, P. D., Antar, M. S. M. \& Zalmout, I. S. 2019. Aegicetus gehennae, a new late Eocene protocetid (Cetacea, Archaeoceti) from Wadi Al Hitan, Egypt, and the transition to tail-powered swimming in whales Smith, T. (ed.). PLOS ONE, 14, e0225391, doi: 10.1371/journal.pone.0225391.

Gingerich P.D., Arif M., Bhatti M.A., Raza H. a., Raza S.M. 1995. Protosiren and Babiacetus (Mammalia, Sirenia and Cetacea) from the middle Eocene Drazinda Formation, Sulaiman Range, Punjab (Pakistan). Contrib. from Museum Paleontol. Univ. Michigan. 29:331-357.

Gingerich, P. D., Ul-Haq, M., Khan, I. H. \& Zalmout, I. S. 2001. Eocene stratigraphy and archaeocete whales (Mammalia, Cetacea) of Drug Lahar in the Eastern Sulaiman Range, Balochistan (Pakistan). Contributions from the Museum of Paleontology - University of Michigan, 30, 269-319.

Gol'din, P. E. \& Zvonok, E. 2013. Basilotritus uheni, a New Cetacean (Cetacea, Basilosauridae) from the Late Middle Eocene of Eastern Europe. Journal of Paleontology, 87, 254-268, doi: 10.1666/12-080R.1.

Luo, Z.-X. \& Gingerich, P. D. 1999. Terrestrial Mesonychia to Aquatic Cetacea: Transformation of the Basicranium and Evolution of Hearing in Whales. University of Michigan - Papers on Paleontology, 31, 1-98.

Marcano-Caldera, M., Mejia-Cardona, J. L., Blanco-Uribe, M. del P., Chaverra-Mesa, E. C., Rodríguez-Lezama, D. \& Parra-Sánchez, J. H. 2019. Fused roots of maxillary molars: characterization and prevalence in a Latin American sub-population: a cone beam computed tomography study. Restorative Dentistry \& Endodontics, 44, 1-12, doi: 10.5395/rde.2019.44.e16.

Martínez-Cáceres, M. \& de Muizon, C. 2011. A new basilosaurid (Cetacea, Pelagiceti) from the Late Eocene to Early Oligocene Otuma Formation of Peru. Comptes Rendus Palevol, 10, 517-526, doi: 10.1016/j.crpv.2011.03.006.

Martínez-Cáceres, M., Lambert, O. \& Muizon, C. de. 2017. The anatomy and phylogenetic affinities of Cynthiacetus peruvianus, a large Dorudon-like basilosaurid (Cetacea, Mammalia) from the late Eocene of Peru. Geodiversitas, 39, 7-163, doi: $10.5252 / \mathrm{g} 2017 \mathrm{n} 1 \mathrm{a} 1$.

Peiris, R., Malwatte, U., Abayakoon, J. \& Wettasinghe, A. 2015. Variations in the Root Form and Root Canal Morphology of Permanent Mandibular First Molars in a Sri Lankan Population. Anatomy Research International, 2015, 1-7, doi: 10.1155/2015/803671.

Thewissen, J. G. M. \& Bajpai, S. 2009. New skeletal material of Andrewsiphius and Kutchicetus, two Eocene cetaceans from India. Journal of Paleontology, 83, 635-663, doi: 10.1666/08-045.1.

Thewissen, J. G. M. \& Hussain, S. T. 2000. Attockicetus praecursor, a new remingtonocetid 
cetacean from marine eocene sediments of Pakistan. Journal of Mammalian Evolution, 7, 133-146, doi: 10.1023/A:1009458618729.

Uhen, M. D. 1998. Middle to Late Eocene Basilosaurines and Dorudontines. In: Thewissen, J. G. M. (ed.) The Emergence of Whales. Plenum Press, New York and London, 29-62.

Vautrin, Q., Lihoreau, F., Sambou, B., Thiam, M., Martin, J. E., Tabuce, R., Adnet, S., Lebrun, R., Charruault, A.-L., Sarr, R. \& Hautier, L. 2020. From limb to fin: an Eocene protocetid forelimb from Senegal sheds new light on the early locomotor evolution of cetaceans. Palaeontology, 63, 51-66, doi: 10.1111/pala.12442. 
Text 2. Phylogenetic analysis - Character's list

CRANIAL

AUDITORY REGION

DENTAL

DENTARY

VERTEBRAL, STERNAL AND RIB

PECTORAL AND FORELIMB

PELVIC AND HINDLIMB

NEW CHARACTERS
Ch. 01 to 34

Ch. 35 to 74

Ch. 75 to 94

Ch. 95 to 98

Ch. 99 to 122

Ch. 123 to 139

Ch. 140 to 148

Ch. 149 to 167 


\section{CRANIAL}

\section{Skull length:}

Character 1 Gol'din \& Zvonok (2013) - Character 3 Geisler et al. (2005)

0 . short, length $<700 \%$ of condylar breadth

1. moderate length, $700 \%-800 \%$ of condylar breadth

2. elongate, $>800 \%$ of condylar breadth

\section{Rostrum length:}

This study - modified from Character 08 Thewissen \& Hussain (2000)

0 . anterior to orbit equal or smaller than the length of skull posterior to orbit

1. anterior to orbit approximately 1.5 times the length of skull posterior to orbit

2. anterior to orbit approximately two times the length of skull posterior to orbit

3. anterior to orbit approximately three times the length of skull posterior to orbit

3. Anterior margin of external nares:

Character 2 Gol'din \& Zvonok (2013) - Character 4* Geisler et al. (2005)

$0 . \quad$ anterior to $\mathrm{I} 3$

1. dorsal or immediately posterior to I3

2. dorsal to I3 to canine diastema

3. dorsal to canine

4. posterior to canine (Geisler et al. 2005)

4. Posterior margin of external nares:

Character 3 Gol'din \& Zvonok (2013) - Character 5* Geisler et al. (2005) - modified from Geisler \& Luo (1998)

$0 . \quad$ anterior to $\mathrm{P} 1$

1. dorsal to P1

2. between $\mathrm{P} 1$ and $\mathrm{P} 2$

3. dorsal or posterior to $\mathrm{P} 2$

\section{Palatine fissure:}

Character 2 Geisler et al. (2005)

$0 . \quad$ present

1. absent

\section{Palate:}

Character 5 Gol'din \& Zvonok (2013) - Character 6 Geisler et al. (2005)

0 . concave transversely

1. flat transversely

2. convex transversely

\section{Palatal process of premaxilla:}

Character 6 Gol'din \& Zvonok (2013) - Character 7 Geisler et al. (2005)

0 . short, terminates anterior or at posterior edge of canine

1. between canine and P1

2. at P1

3. posterior to $\mathrm{P} 1$ 
8. Ascending process of premaxilla:

Character 7 Gol'din \& Zvonok (2013) - Character 8 Geisler et al. (2005)

0 . terminates posteriorly, anterior to or over P1

1. over P2

2. over diastema between $\mathrm{P} 2$ and $\mathrm{P} 3$

3. over or posterior to P3

9. Embrasure pits between I1-I2 and I2-I3:

This study - modified from Thewissen \& Bajpai (2009) - Character 7 Gol'din \& Zvonok (2013) - Character 9 Geisler et al. (2005)

$0 . \quad$ absent

1. present ventrally

2. occurs on lateral and ventral surfaces of maxilla

10. Embrasure pit between $\mathbf{C}$ and I3:

This study - modified from Thewissen \& Bajpai (2009) - Character 8 Gol'din \& Zvonok (2013) - Character 10 Geisler et al. (2005)

0 . absent

1. present ventrally

2. occurs on lateral and ventral surfaces of maxilla

11. Embrasure pit between P1 and C:

Character 10 Gol'din \& Zvonok (2013) - Character 11 Geisler et al. (2005)

0 . absent

1. small, located on ventral surface of maxilla

2. deep but contained on ventral surface

3. occurs on lateral and ventral surfaces of maxilla

12. Palate narrows:

Character 11 Gol'din \& Zvonok (2013) - Character 14* Geisler et al. (2005)

0 . posterior to $\mathrm{M} 3$

1. at $\mathrm{M} 3$

2. at $\mathrm{M} 2$

3. at M1

4. at $\mathrm{P} 4$

5. the palate does not narrow

13. Rostrum breadth at M2:

Character 13 Geisler et al. (2005)

0 . wide, width at $\mathrm{M} 2>140 \%$ the condylar width

1. narrow, width at $\mathrm{M} 2<120 \%$ the maximum width across the occipital condyles

14. Posterior margin of nasal in relation to the PMM (posterior margin of maxilla) in dorsal view:

Character 4 Gol'din \& Zvonok (2013) - modified from Uhen et al. (2011) - PMM posterior margin of maxilla

0. posterior to PMM

1. anterior or at the same level as PMM 


\section{Nasal process of frontal:}

Character 12 Gol'din \& Zvonok (2013) - Character 15 Geisler et al. (2005) - modified from Uhen (1998)

0 . absent

1. present, frontal with small $(<3 \mathrm{~mm})$ process that lies medial to the posterior end of the nasal

2. frontal with large nasal process

16. Supraorbital process:

Character 13 Gol'din \& Zvonok (2013) - Character 16 Geisler et al. (2005) - Barnes (1984) - modified from Uhen (1998)

0 . absent, frontal shield width $<180 \%$ the condylar breadth

1. present but small, $180 \%<$ frontal shield width $<190 \%$ of condylar breadth

2. present, $190 \%<$ frontal shield width $<240 \%$ of condylar breadth

3. greatly enlarged, $>245 \%$ of condylar breadth

17. Anterior edge of orbit:

Character 14 Gol'din \& Zvonok (2013) - Character 19 Geisler et al. (2005) - Geisler (2001)

$0 . \quad$ over or posterior to M3

1. over $\mathrm{M} 2$ or $\mathrm{M} 2 / \mathrm{M} 3$ division

2. over $\mathrm{M} 1$ or $\mathrm{M} 1 / \mathrm{M} 2$ division

3. over $\mathrm{P} 4$ or $\mathrm{P} 4 / \mathrm{M} 1$ division

18. Posterior edge of postorbital process:

Character 15 Gol'din \& Zvonok (2013) - Character 20 Geisler et al. (2005) - modified from Uhen (1998)

0 . forms highly obtuse angle with sagittal crest (angle of anterior border of temporal fossa)

1. oriented at approximately $90^{\circ}$ to sagittal crest

2. forms acute angle with sagittal crest due to posterior swelling of lateral end

19. Orbit:

Character 18 Geisler et al. (2005)

0 . elevated highly above toothrow

1. elevated slightly above toothrow

20. Orbit size:

This study - modified from Character 07 Uhen (1998) - Character 17 Geisler et al. (2005)

0 . small, vertical diameter of orbit $<30 \%$ of condylar breadth

1. medium, vertical diameter of orbit between $30 \%$ and $60 \%$ of condylar breadth

2. large, vertical diameter of orbit $>60 \%$ of condylar breadth

21. Orientation of supraoccipital shield:

Character 20 Gol'din \& Zvonok (2013) - Character 32 Geisler et al. (2005) - modified from Uhen (1998)

0 . posterodorsally 
1. vertical above foramen magnum

2. anterodorsally

22. Fossa for insertion of rectus capitus lateralis muscle:

Character 21 Gol'din \& Zvonok (2013) - Character 36 Geisler et al. (2005) - (narrow part of fan points medially)

$0 . \quad$ absent

1. present as ovoid pit lateral to occipital condyle

2. present and divided into two smaller fossae which share the larger depression

23. Fan-shaped fossa on exoccipital dorsal to paroccipital process:

Character 22 Gol'din \& Zvonok (2013) - Character 37 Geisler et al. (2005) - see description in text Gol'din \& Zvonok (2013)

0 . absent

1. present

24. Dorsoventral row of muscular fossae on lateral edge of exoccipital:

Character 23 Gol'din \& Zvonok (2013) - Character 38 Geisler et al. (2005)

0 . absent

1. present

25. Nuchal rise:

Character 119 Gibson et al. (2019)

$0 . \quad$ absent

1. sharp

2. broad

26. Nuchal crests:

Character 31 Geisler et al. (2005)

$0 . \quad$ oriented laterally

1. lateral ends are gently curved posterolaterally

2. form a horseshoe shape in dorsal view that is open posteriorly

27. Nuchal tubercles:

Character 34 Geisler et al. (2005)

0 . absent

1. present on dorsal edge of foramen magnum

28. Parietal ridge:

Character 120 Gibson et al. (2019)

0 . present

1. absent

29. Cerebellar rete (as determined in endocasts or a visible cranial cavity):

Character 33 Geisler et al. (2005)

0 . absent or indistinguishable from the rest of the endocast

1. occurs dorsal and medial to petrosal

2. occurs dorsal and medial to petrosal as well dorsal to the cerebellum

3. hypertrophied completely surrounding the dorsal surface of the cerebellum and the trigeminal nerve and towers above the endocast of the cerebral hemispheres 
30. Palate angulation:

This study - modified from Character 108 Bianucci \& Gingerich (2011) -

Clinorhynchy

$0 . \quad \theta_{1}$ negative

1. $\theta_{1}$ neutral

2. $\theta_{1}$ positive

31. Frontal angulation:

This study - modified from Character 108 Bianucci \& Gingerich (2011) -

Clinorhynchy

0. $\quad \theta_{2}<\theta_{3}$

1. $\theta_{2}>\theta_{3}$

32. Foramen ovale:

Character 23 Geisler et al. (2005)

0 . within the alisphenoid

1. at squamosal and alisphenoid suture but open ventrally

2. at squamosal/alisphenoid suture but completely enclosed

3. merged with piriform fenestra

33. Pterygoid sinus:

Character 16 Gol'din \& Zvonok (2013) - Character 24 Geisler et al. (2005) - modified from Luo \& Gingerich (1999)

0 . absent

1. present but obscured in ventral view by the bulla, occupies region between anterior end of involucrum and alisphenoid portion of pterygoid ridge

2. breaches posterior wall of tube for foramen ovale and extends slightly anterior to the anterior edge of the tympanic bulla

3. enlarged, forms a deep anteroposterior trough which approaches the internal nares

34. Lateral extent of exoccipital in ventral view:

Character 18 Gol'din \& Zvonok (2013) - Character 29 Geisler et al. (2005)

0 . same as or less than the mastoid process of petrosal

1. greater than mastoid process of petrosal

\section{AUDITORY REGION}

35. Anterior process of petrosal (anterior extension of tegmen tympani):

Character 40 Geisler et al. (2005)

0 . absent

1. present, anterior edge of tegmen tympani extends far anterior to the edge of the pars cochlearis

36. Anterior process of petrosal:

Character 24 Gol'din \& Zvonok (2013) - Character 41 Geisler et al. (2005) - Luo \& Gingerich (1999) 
0. articulates laterally with the entoglenoid (falciform) process of the squamosal but is exposed ventrally

1. anterior two-thirds of the anterior process completely overlapped ventrally by the entoglenoid process

37. Fossa for tensor tympani muscle:

Character 25 Gol'din \& Zvonok (2013) - Character 45 Geisler et al. (2005) - modified from Luo \& Marsh (1996)

0 . $\quad$ shallow, bowl-shaped pit

1. deep groove that is partially hidden in ventral view by a medial shelf of the tegmen tympani

2. deep groove that is clearly visible

3. absent

38. Concave facet of promontorium:

Character 91 Mourlam \& Orliac (2018)

0 . absent

1. present

39. Shape of concave facet of promontorium:

Character 92 Mourlam \& Orliac (2018)

0 . broad and deep

1. broad and shallow

2. narrow and shallow

40. Size of crista interfenestralis:

Character 93 Mourlam \& Orliac (2018)

0 . thin (smaller than that of the length of the fenestra vestibuli)

1. average (same size as the length of the fenestra vestibuli)

2. large (larger than that of the length of the fenestra vestibuli)

41. Position of the secondary facial foramen:

Character 95 Mourlam \& Orliac (2018)

0 . anterolateral to the fenestra vestibuli

1. lateral to the fenestra vestibuli

2. posterior to the fenestra vestibuli

42. Edge of internal acoustic meatus:

Character 26 Gol'din \& Zvonok (2013) - Character 47 Geisler et al. (2005)

0 . flush or nearly flush with the surrounding endocranial surface of petrosal

1. forms a tube that projects mediodorsally into the endocranial cavity

43. Anteroventral side of the IAM:

Character 94 Mourlam \& Orliac (2018)

$0 . \quad$ large shelf

1. thin, riddled with foramina

44. Stylomastoid foramen:

Character 49 Geisler et al. (2005) 
0. forms a large open notch, petrosal does not contact the petrosal either anterior or posterior to the fenestra rotunda

1. is complete, ectotympanic contacts tympanohyal laterally and the petrosal medially, in some cases ectotympanic separated from petrosal by a narrow $(<1$ $\mathrm{mm}$ ) fissure

\section{Entoglenoid process:}

This study - modified from Character 33 Gol'din \& Zvonok (2013) - Character 60* Geisler et al. (2005) - Luo \& Gingerich (1999)

0 . absent

1. present

\section{Entoglenoid process shape:}

This study - modified from Character 33 Gol'din \& Zvonok (2013) - Character 60* Geisler et al. (2005) - Luo \& Gingerich (1999)

$0 . \quad$ ovoid

1. drop shape (incipient falciform)

2. falciform

3. sub-rectangular

4. thin ridge

47. External auditory meatus:

Character 17 Gol'din \& Zvonok (2013) - Character 28* Geisler et al. (2005) modified from Luo \& Gingerich (1999)

0 . short, $17 \%<$ length of meatus $<25 \%$ half of the basicranial width

1. long, $25 \%<$ length of meatus $<40 \%$

2. very long, $40 \%<$ length of meatus $<47 \%$

3. elongate, $>50 \%$ of half of the basicranial width

48. Tympanic ring:

Character 50 Geisler et al. (2005)

0 . simple ring or a annulus of thin bone projects from dorsal surface of the bulla

1. annulus not visible, instead the middle conical process present in the homologous position

49. Meatal portion of ectoympanic:

Character 53 Geisler et al. (2005)

0 . tympanic does not extend ventral to external auditory meatus

1. tympanic extends laterally forming the floor of the external auditory meatus

50. Lateral furrow of tympanic:

Character 56 Geisler et al. (2005)

0 . absent

1. present

51. Sigmoid process and the transverse rim on it:

Character 29 Gol'din \& Zvonok (2013) - Character 54* Geisler et al. (2005)

0 . plate and thin sigmoid process, no transverse rim

1. plate and broad sigmoid process, low transverse rim

2. robust and broad sigmoid process, high transverse rim 


\section{Tip of sigmoid process:}

Character 30 Gol'din \& Zvonok (2013) - Character 55 Geisler et al. (2005) - modified from Luo \& Gingerich (1999)

0 . points posterodorsally

1. forms anteroposteriorly broad, transverse plate

53. Base of posterior process of tympanic:

This study - modified from Character 32 Gol'din \& Zvonok (2013) - Character 59*

Geisler et al. (2005) - Kasuya (1973)

0 . forms a single columnar pedicle

1. perforated and forms medial and lateral pedicles

54. Articulation of medial edge of the TB with basioccipital:

Character 35 Gol'din \& Zvonok (2013) - Character 62 Geisler et al. (2005) - Luo \&

Gingerich (1999) - TB tympanic bulla

0 . present

1. absent

55. Basioccipital crests (falcate processes):

Character 27 Geisler et al. (2005)

0 . absent

1. present, forming ventrolaterally flaring basioccipital processes

2. present and extremely wide transversely and narrow anteroposteriorly

56. Posterior edge of tympanic:

Character 36 Gol'din \& Zvonok (2013) - Character 64 Geisler et al. (2005) - Geisler

\& Luo (1998) - Luo \& Gingerich (1999)

0 . does not contact exoccipital

1. contacts paraoccipital process of exoccipital

57. Angle medial:

Character 78 Mourlam \& Orliac (2018) - between anterior part of the medial posterior prominence and the anteromedial side of ectotympanic

$0 . \quad$ acute angle

1. obtuse angle

2. straight angle

58. Angle lateral:

Character 79 Mourlam \& Orliac (2018) - between anterior part of the lateral posterior prominence and the anterolateral side of ectotympanic

$0 . \quad$ absent

1. present

59. Median furrow of tympanic:

Character 31 Gol'din \& Zvonok (2013) - Character 57* Geisler et al. (2005) modified from Geisler \& Luo (1998) - Luo \& Gingerich (1999)

0 . forms narrow notch on posterior edge of bulla in ventral view

1. forms broad embayment of posterior edge of bulla 
2. bisects bulla into a smaller posteromedial and a larger posterolateral portions

60. Size medial posterior prominence ( $\mathrm{mp})$ - lateral posterior prominence (lp):

Character 80 Mourlam \& Orliac (2018)

$0 . \quad \mathrm{mp}>\mathrm{lp}$

1. $m p=1 p$

2. $\mathrm{mp}<\mathrm{lp}$

61. Medial sulcus:

Character 81 Mourlam \& Orliac (2018)

0 . absent

1. present

62. Position of external opening of the eustachian tube:

Character 27 Gol'din \& Zvonok (2013) - Character 52 Geisler et al. (2005) - Luo \& Gingerich (1999)

0 . at anterior end of bulla

1. on medial side of bulla

2. at anterior end of bulla, but anterior half of involucrum is thin

63. Involucrum of bulla:

Character 51 Geisler et al. (2005)

$0 . \quad$ absent

1. present

64. Medial keel:

Character 77 Mourlam \& Orliac (2018) - on the medial side of ectotympanic

0 . absent

1. present

65. Shape of involucrum in dorsoventral view:

Character 28 Gol'din \& Zvonok (2013)

0 . club-shaped

1. angled posteromedially

2. drop-shaped

66. Shape of the dorsal surface of the involucrum:

Character 82 Mourlam \& Orliac (2018)

0 . club shaped

1. sub-circular pit

2. drop shaped

3. shamrock

4. sub-circular dome

67. Transinvolucrum sulcus (Tis):

Character 83 Mourlam \& Orliac (2018)

0 absent

1. present 
68. Tis width:

Character 84 Mourlam \& Orliac (2018)

0 . broad

1. thin line

69. Tis depth:

Character 85 Mourlam \& Orliac (2018)

0 shallow

1. marked

2. deep (fovea)

70. Tuberosity of the involucrum $n^{\circ}$ :

Character 86 Mourlam \& Orliac (2018)

0 . absent

1. present

71. Tuberosity of the involucrum $n^{\circ}$ 2:

Character 87 Mourlam \& Orliac (2018)

0 . absent

1. present

72. Tuberosity of the involucrum $n^{\circ} 3$ :

Character 88 Mourlam \& Orliac (2018)

0 . absent

1. present

73. Tuberosity of the involucrum $n^{\circ}$ 4:

Character 89 Mourlam \& Orliac (2018)

0 . absent

1. present

74. Tuberosity of the involucrum $n^{\circ}$ 5:

Character 90 Mourlam \& Orliac (2018)

0 . absent

1. present

\section{DENTAL}

75. I2 length:

This study - modified from Character 65 Geisler et al. (2005)

0 . substantially smaller than canine

1. subequal to canine

2. longer than canine

76. P1 and p1:

Character 37 Gol'din \& Zvonok (2013) - Character 66 Geisler et al. (2005)

0 . substantially smaller than canines 
1. $\quad$ subequal to canine in size (Geisler et al. 2005)

77. Accessory cusps on posterior premolars and molars:

Character 38 Gol'din \& Zvonok (2013) - Character 67 Geisler et al. (2005) - lowers and uppers

0 . absent

1. present but small

2. present and large (modified from Uhen 1998; Geisler et al. 2005)

78. P1 roots:

Character 39* Gol'din \& Zvonok (2013) - Character 68 Geisler et al. (2005)

0 . absent

1. one root

2. $\quad$ two roots (Uhen 1999; Geisler et al. 2005)

79. P1 roots:

Character 40 Gol'din \& Zvonok (2013) - Character 69 Geisler et al. (2005)

$0 . \quad$ one root

1. two roots (Uhen 1999; Geisler et al. 2005)

80. P3 length:

Character 70 Geisler et al. (2005) - modified from Thewissen \& Hussain (2000)

$0 . \quad$ shorter than length of $\mathrm{P} 4$

1. subequal to $\mathrm{P} 4$ length

2. longer than $\mathrm{P} 4$

81. Paraconid on lower molars:

Character 71 Geisler et al. (2005)

$0 . \quad$ present and large

1. small and much lower than protoconid

2. absent

82. Carnassial notch on lower molars:

Character 72 Geisler et al. (2005)

0 . absent

1. present

83. Trigonid of molars:

Character $73 *$ Geisler et al. (2005) - at least on $m 2-m 3$

0 . flat anterior border

1. concave with a reentrant groove, accommodates posterior convex border of the talonid or adjacent tooth

84. Talonid of $\mathbf{m} 1$ and $\mathbf{m} 2$ :

Character 74 Thewissen \& Bajpai (2009) modified from Character 74 Geisler et al. (2005)

$0 . \quad$ trigonid longer than talonid

1. trigonid and talonid similar in length

2. talonid longer than trigonid 


\section{Enamel of $\mathbf{P}$ :}

Character 41 Gol'din \& Zvonok (2013)

0 . ornamented

1. smooth (modified from Gingerich \& Uhen 1996)

86. Prominent denticulate cingula on P2-P4:

Character 42 Gol'din \& Zvonok (2013) - modified from Köhler \& Fordyce (1997)

0 . absent

1. $\quad$ present (modified from Köhler \& Fordyce 1997)

87. P3 protocone:

This study - modified from Character 43 Gol'din \& Zvonok (2013) - modified from Gingerich et al. (1995a)

0 . present and large

1. present but is minute cusp

2. protocone lobe e.g. see Gingerich et al. (1995b); Thewissen \& Bajpai (2009)

3. absent (modified from Gingerich et al. 1995a)

88. P4 protocone:

This study - modified from Character 43 Gol'din \& Zvonok (2013) - modified from Gingerich et al. (1995a)

$0 . \quad$ present and large

1. present but is minute cusp

2. protocone lobe e.g. see Gingerich et al. (1995b); Thewissen \& Bajpai (2009)

3. absent (modified from Gingerich et al. 1995a)

89. M1 protocone:

This study - modified from Character 44 Gol'din \& Zvonok (2013) - Character 75 Geisler et al. (2005)

$0 . \quad$ present and large

1. present but is minute cusp

2. protocone lobe e.g. see Gingerich et al. (1995b); Thewissen \& Bajpai (2009)

3. absent (Thewissen \& Hussain 2000; Geisler et al. 2005)

90. M2 protocone:

This study - modified from Character 44 Gol'din \& Zvonok (2013) - Character 75 Geisler et al. (2005)

0 . present and large

1. present but is minute cusp

2. protocone lobe e.g. see Gingerich et al. (1995b); Thewissen \& Bajpai (2009)

3. absent (Thewissen \& Hussain 2000; Geisler et al. 2005)

91. M1 roots: 
This study - modified from Character 45 Gol'din \& Zvonok (2013) - Character 76* Geisler et al. (2005)

$0 . \quad$ three roots

1. two roots

92. M2 roots:

This study - modified from Character 46 Gol'din \& Zvonok (2013) - Character 77* Geisler et al. (2005)

$0 . \quad$ three roots

1. two roots

93. M3:

Character 47 Gol'din \& Zvonok (2013) - Character 78* Geisler et al. (2005)

0 . present and roughly equal in size to M2

1. present but small, maximum mesodistal $<60 \%$ the length of M2

2. absent (modified from Zhou et al., 1995; Geisler and Luo, 1998; Geisler et al., 2005)

94. M3 roots:

This study - modified from Character 48 Gol'din \& Zvonok (2013) - Character 79* Geisler et al. (2005)

$0 . \quad$ three roots

1. two roots

\section{DENTARY}

95. Mandibular symphysis posterior termination:

Character 49 Gol'din \& Zvonok (2013) - Character 80* Geisler et al. (2005) - Uhen (1998)

$0 . \quad$ below $\mathrm{p} 1$

1. below $\mathrm{p} 2$

2. below diastema between $\mathrm{p} 2$ and $\mathrm{p} 3$, or $\mathrm{p} 3$

3. posterior to $\mathrm{p} 3$

4. below or posterior to $\mathrm{p} 4$

Uhen (1998); Geisler et al. (2005)

96. Mandibular symphysis:

Character 50 Gol'din \& Zvonok (2013) - Character 81 Geisler et al. (2005) - Uhen (1998)

$0 . \quad$ suture visible

1. fused

97. Mandibular foramen size:

Character 82* Geisler et al. (2005) - modified from Thewissen (1994) - Geisler \& Luo (1998)

0 . small, maximum height of opening $25 \%$ or less the height of mandible at $\mathrm{m} 3$

1. medium size, between 25 and $50 \%$

2. greatly enlarged, maximum height greater than $50 \%$ the height of the mandible at $\mathrm{m} 3$ 
98. Coronoid height:

Character 114 Lambert et al. (2019)

$0 . \quad$ high

1. low

\section{VERTEBRAL, STERNAL AND RIB}

99. Articulation facets on the atlas for the axis:

Character 53 Gol'din \& Zvonok (2013) - Character 85* Geisler et al. (2005)

$0 . \quad$ convex

1. flat

2. concave

100. Hypophysis of axis in ventral view:

Character 54 Gol'din \& Zvonok (2013) - Character 84 Geisler et al. (2005)

0 . steep-sided cone, transverse width $<1.5$ times its anteroposterior length

1. low with no clear separation from lateral articulation facets for the atlas, transverse width $>2$ times its anteroposterior length

101. Vertebrarterial foramen in the axis:

Character 55 Gol'din \& Zvonok (2013) - modified from Martínez-Cáceres \& Muizon (2011)

$0 . \quad$ moderate or large

1. small or absent

102. Vertebrarterial foramen of transverse processes in C3-C7:

Character 56 Gol'din \& Zvonok (2013) - modified from Martínez-Cáceres \& Muizon (2011)

0. moderate or large

1. small

103. Cervical vertebra:

Character 87 Geisler et al. (2005)

0 . long, length of centra greater than or equal those of anterior thoracics

1. short, length shorter than anterior thoracics

104. Number of thoracic vertebrae:

Character 58 Gol'din \& Zvonok (2013) - Character 88* Geisler et al. (2005) modified from Uhen (1998) - Martínez-Cáceres \& Muizon (2011)
$0 . \quad<10$
1. $\quad 11-14$
2. $>14$

105. Spinous processes of $\mathrm{T} 6$ and $\mathrm{T} 7$ :

Character 89 Geisler et al. (2005)

0 . steeply inclined from plane of the anterior face of the centrum $>25^{\circ}$ 
1. gently inclined to vertical $<15^{\circ}$

106. Centrum shape of thoracic vertebrae:

Character 89 Vautrin et al. (2020)

0 . heart shape, ratio width/height $<140 \%$

1. flattened ventrally, ratio $>140 \%$

107. Thoracic vertebrae width:

Character 90 Vautrin et al. (2020)

0 . broad vertebrae, length/height $<1.1$

1. long length/height $>1.1$

108. Depression behind the prezygapophyses:

Character 91 Vautrin et al. (2020)

0 absent

1. present

109. Depression shape behind the prezygapophyses:

Character 92 Vautrin et al. (2020)

0 . deep and round

1. shallow and elliptic

110. Transverse processes orientation:

Character 93 Vautrin et al. (2020)

$0 . \quad$ laterally

1. laterally and dorsally

111. Supraneural shelf:

Character 94 Vautrin et al. (2020)

0 . absent

1. present

112. Neural spine of the thoracic vertebrae:

Character 95 Vautrin et al. (2020)

$0 . \quad$ long and thin

1. short

113. Sternum shape:

Character 64 Gol'din \& Zvonok (2013) - modified from Uhen et al. (2011)

0 . T-shaped manubrium, with rod-shaped elements

1. thick, rectangular manubrium with thick, polygonal elements

2. broad flat manubrium and elements

114. First five ribs:

Character 65 Gol'din \& Zvonok (2013) - Character 97 Geisler et al. (2005)

0 . distal ends similar in diameter to proximal portions

1. distal ends expanded and bulbous

115. Change in angle (CIA) in anterior rib: 
Character 96 Vautrin et al. (2020)

$0 . \quad$ CIA proximal

1. CIA distal

116. Number of lumbar vertebrae:

This study - character state modified based on Gingerich et al. (2019) - Character 59 Gol'din \& Zvonok (2013) - Character 90* Geisler et al. (2005) - modified from Uhen (1998) - Martínez-Cáceres \& Muizon (2011)
0.4
1. $6-7$
2. 8
3. $9-14$
4. $>14$

117. Elongation of vertebrae of posterior half of vertebral column:

Character 60 Gol'din \& Zvonok (2013) - Character 91* Geisler et al. (2005) whichever is longer

0 . short: centrum length $<150 \%$ the centrum height

1. moderate: $150 \%<$ centrum length $<250 \%$ the centrum height

2. elongate: centrum length $>250 \%$ the centrum height

118. Lumbar zygapophyses:

Character 61 Gol'din \& Zvonok (2013) - Character 92 Geisler et al. (2005) - Uhen (1998)

$0 . \quad$ revolute

1. curved

2. flat

3. absent

119. Number of postlumbar vertebrae articulating via pleuropophyses:

Character 96 Geisler et al. (2005)

0 . more than four

1. four

2. three

3. two

4. none

120. Articulation between sacral vertebrae and ilium of pelvis:

Character 62 Gol'din \& Zvonok (2013) - Character 93 Geisler et al. (2005) - Uhen (1998)

0 . broad area of articulation between pelvis and one or two sacral vertebrae

1. no articulation between vertebrae and pelvis

121. Number of vertebrae fused together to form a sacrum:

Character 63 Gol'din \& Zvonok (2013) - Character 94* Geisler et al. (2005) modified from Uhen (1998)

$0 . \quad$ no fusion

1. two

2. more than two

122. Transverse processes of sacral vertebrae: 
Character 95 Geisler et al. (2005)

$0 . \quad$ short

1. long

PECTORAL AND FORELIMB

\section{Shape of scapula:}

Character 66 Gol'din \& Zvonok (2013) - modified from Gingerich \& Uhen (1996)

$0 . \quad$ flat

1. narrow

124. Humerus capitulum:

This study - modified from Character 99 Vautrin et al. (2020) based on Thewissen \& Bajpai (2009)

$0 . \quad$ present

1. incipient (narrow and flat)

2. absent

125. Ulna and radius shape:

Character 100 Vautrin et al. (2020)

$0 . \quad$ long and straight

1. short and curved

126. Radius:

Character 68 Gol'din \& Zvonok (2013) - Character 98 Geisler et al. (2005) - Uhen (1998)

$0 . \quad$ circular to slightly ovoid in cross section

1. flattened mediolaterally, highly elliptical in cross section

127. Distal end of ulna:

Character 100 Geisler et al. (2005)

0 . pointed

1. broad anteroposteriorly

128. Ulna pisiform articulation:

Character 102 Vautrin et al. (2020)

0 . absent

1. present

129. Pisiform size:

Character 110 Vautrin et al. (2020)

0 . smaller than the metacarpal V

1. same size or bigger than the metacarpal $\mathrm{V}$

130. Orientation of the pisiform:

Character 105 Vautrin et al. (2020)

0 . dorsally oriented

1. laterally oriented

131. Lunar size:

Character 103 Vautrin et al. (2020) 
0. smaller or same size than the pyramidal

1. bigger than the pyramidal

132. Unciform size:

Character 104 Vautrin et al. (2020)

0 . bigger than the cuneiform

1. same size than the cuneiform

133. Lunar size in comparison to the unciform:

Character 107 Vautrin et al. (2020)

0 . equal or bigger than the unciform

1. smaller than the unciform

134. Trapezoid and magnum:

Character 69 Gol'din \& Zvonok (2013) - Character 101 Geisler et al. (2005) - Uhen (1998)

$0 . \quad$ separate

1. fused

135. Distal carpal articular surfaces:

Character 70 Gol'din \& Zvonok (2013) - Character 102 Geisler et al. (2005) - Uhen (1998)

$0 . \quad$ curved to allow for substantial movement

1. flat

136. Proximal phalanx III length:

Character 106 Vautrin et al. (2020)

0 . smaller or equal to metacarpal III length

1. longer than metacarpal III length

137. Length of the medial phalanx $V$ :

Character 108 Vautrin et al. (2020)

0 . same as the medial phalanx II

1. longer and thinner

138. Digit I:

Character 109 Vautrin et al. (2020)

0 . present

1. absent

139. Hooves:

Character 101 Vautrin et al. (2020)

0 . present

1. absent

PELVIC AND HINDLIMB

140. Pelvis size:

Character 71 Gol'din \& Zvonok (2013) - Character 103 Geisler et al. (2005) 
0. large, has well-developed ilium with total length $>300 \%$ the length of the first sacral vertebra

1. greatly reduced with a small ilium, total length of the length of the first sacral vertebra

\section{Obturator foramen:}

Character 72 Gol'din \& Zvonok (2013) - Character 104 Geisler et al. (2005) modified from Hulbert (1998)

$0 . \quad$ larger than acetabulum

1. smaller than acetabulum

142. Dorsal edge of acetabulum:

Character 73 Gol'din \& Zvonok (2013) - Character 105 Geisler et al. (2005) Gingerich et al. (1995b)

$0 . \quad$ high and sharp

1. low and rounded

143. Ventromedial expansion of pubis ventro-medial to OF:

Character 74 Gol'din \& Zvonok (2013) - Character 106 Geisler et al. (2005) - Hulbert (1998) - Uhen (1999) - OF obturator foramen

0 . absent

1. present but small expansion

2. present and extreme expansion

144. Anterior border of cranial pubic ramus:

Character 116 Lambert et al. (2019)

$0 . \quad$ very concave

1. slightly concave

\section{Ilion neck size:}

Character 97 Vautrin et al. (2020)

$0 . \quad$ massive

1. long and narrow

2. reduced

146. Projection of the ischium:

Character 98 Vautrin et al. (2020)

0 . projected clearly dorsally, little posteriorly, creates a marked curvature of the dorsal margin

1. projected dorsally and dorso-posteriorly, slight curvature of the dorsal margin

2. projected mainly dorso-posteriorly, no curvature of the dorsal margin

\section{Femur:}

Character 75 Gol'din \& Zvonok (2013) - Character 107 Geisler et al. (2005) - Uhen (1998)
$0 . \quad$ large
1. moderate
2. small

\section{Fovea capitis femoris:}


Character 76 Mourlam \& Orliac (2018)

0 . absent

1. present

NEW CHARACTERS

149. Rostrum breadth at P2:

This study

0 . narrow ( $\mathrm{P} 2$ length is more than $60 \%$ of rostrum breadth)

1. reduced (P2 length is between $50 \%$ and $60 \%$ of rostrum breadth)

2. average (P2 length is between $40 \%$ and $50 \%$ of rostrum breadth)

3. broad (P2 length is less than $40 \%$ of rostrum breadth)

150. Posterior edge of infraorbital foramen:

This study

0 . anterior to $\mathrm{P} 3$

1. above the anterior edge of P3

2. above $\mathrm{P} 3$

3. between $\mathrm{P} 3$ and $\mathrm{P} 4$

4. posterior to $\mathrm{P} 4$

151. Embrasure pit between P2 and P3:

This study

0 . absent

1. present

152. Size of the embrasure pit between $P 2$ and P3:

This study

0. small

1. broad

153. Embrasure pit between $P 3$ and P4:

This study

0 . absent

1. present

154. Size of the embrasure pit between P3 and P4:

This study

0. small

1. broad

155. Embrasure pit between $P 4$ and M1:

This study

0 . absent

1. present

156. Embrasure pit between $M 1$ and M2:

This study

0 . absent 
1. present

157. Size of the embrasure pit between M1 and M2:

This study

0. small

1. broad

158. Embrasure pit between M2 and M3:

This study

0 . absent

1. present

159. Metacone on P2:

This study

0 . absent

1. present

160. Metacone on P3:

This study

0 . absent

1. present

161. Metacone on P4:

This study

0 . absent

1. present

162. Position of metacone on P4:

This study

0. distal, clearly distinct from paracone

1. distal, nearly fused with paracone

2. apical, nearly fused with paracone

3. almost completely fused (i.e. only presence of a sulcus)

163. Metacone size on M2:

0 . subequal to paracone

1. smaller than paracone

164. Position of metacone on M2:

0 . distal, clearly distinct from paracone

1. distal, nearly fused with paracone

2. apical, nearly fused with paracone

3. almost completely fused (i.e. only presence of a sulcus)

165. Doubled preparacrista on M2:

0 . absent 
1. present

166. Acetabular notch:

This study - based on Bebej et al. (2015)

0 . open

1. narrow (nearly closed)

2. closed

167. Femoral head orientation:

This study

0 . perpendicular to shaft

1. about $45^{\circ}$ from the shaft

2. in the continuation of the shaft

\section{References}

Barnes L.G. 1984. Whales, dolphins, and porpoises: origin and evolution of Cetacea. In: Broadhead T.W., editor. Mammals. Notes for a short course organized by P.D. Gingerich and C.E. Badgley. Studies in Geology 8(1-4). University of Tennessee Department of Geological Sciences: p. 139154.

Bebej R.M., Zalmout I.S., Abed El-Aziz A.A., Antar M.S.M., Gingerich P.D. 2015. First remingtonocetid archaeocete (Mammalia, Cetacea) from the middle Eocene of Egypt with implications for biogeography and locomotion in early cetacean evolution. J. Paleontol. 89:882893.

Bianucci G., Gingerich P.D. 2011. Aegyptocetus tarfa, n. gen. et sp. (Mammalia, Cetacea), from the middle Eocene of Egypt: Clynorhynchy, olfaction, and hearing in protocetid whale. J. Vertebr. Paleontol. 31:1173-1188.

Geisler J.H. 2001. New morphological evidence for the phylogeny of Artiodactyla Cetacea and Mesonychidae. Am. Museum Novit. 40:53.

Geisler J.H., Luo Z.-X. 1998. Relationships of Cetacea to Terrestrial Ungulates and the Evolution of Cranial Vasculature in Cete. In: Thewissen J.G.M., editor. The Emergence of Whales. New York and London: Plenum Press. p. 163-212.

Geisler J.H., Sanders A.E., Luo Z.-X. 2005. A New Protocetid Whale (Cetacea: Archaeoceti) from the Late Middle Eocene of South Carolina. Am. Museum Novit. 3480:1-65.

Gibson M.L., Mnieckowski J., Geisler J.H. 2019. Tupelocetus palmeri, a new species of protocetid whale (Mammalia, Cetacea) from the middle Eocene of South Carolina. J. Vertebr. Paleontol. 38:e1555165.

Gingerich P.D., Antar M.S.M., Zalmout I.S. 2019. Aegicetus gehennae, a new late Eocene protocetid (Cetacea, Archaeoceti) from Wadi Al Hitan, Egypt, and the transition to tail-powered swimming in whales. PLoS One. 14:e0225391.

Gingerich P.D., Arif M., Bhatti M.A., Raza H. a., Raza S.M. 1995a. Protosiren and Babiacetus (Mammalia, Sirenia and Cetacea) from the middle Eocene Drazinda Formation, Sulaiman Range, Punjab (Pakistan). Contrib. from Museum Paleontol. Univ. Michigan. 29:331-357.

Gingerich P.D., Arif M., Clyde W.C. 1995b. New archaeocetes (Mammalia, Cetacea) from the Middle Eocene Domanda Formation of the Sulaiman Range, Punjab (Pakistan). Contrib. from Museum Paleontol. Univ. Michigan.

Gingerich P.D., Uhen M.D. 1996. Ancalecetus simonsi, a new dorudontine archaeocete (Mammalia, Cetacea) from the early late Eocene of Wadi Hitan, Egypt. Contrib. from Museum Paleontol. Univ. Michigan. 29:359-401. 
Gol'din P.E., Zvonok E. 2013. Basilotritus uheni, a New Cetacean (Cetacea, Basilosauridae) from the Late Middle Eocene of Eastern Europe. J. Paleontol. 87:254-268.

Hulbert R.C.J. 1998. Postcranial Osteology of the North American Middle Eocene Protocetid Georgiacetus. In: Thewissen J.G.M., editor. The Emergence of Whales. New York and London: Plenum Press. p. 235-267.

Kasuya T. 1973. Systematic consideration of recent toothed whales based on the morphology of the tympano-periotic bone. Sci. Reports Whales Res. Inst.:1-103.

Köhler R., Fordyce R.E. 1997. An Archaeocete Whale (Cetacea: Archaeoceti) from the Eocene Waihao Greensand, New Zealand. J. Vertebr. Paleontol. 17:574-583.

Lambert O., Bianucci G., Salas-Gismondi R., Di Celma C., Steurbaut E., Urbina M., de Muizon C. 2019. An Amphibious Whale from the Middle Eocene of Peru Reveals Early South Pacific Dispersal of Quadrupedal Cetaceans. Curr. Biol. 29:1352-1359.e3.

Luo Z.-X., Gingerich P.D. 1999. Terrestrial Mesonychia to Aquatic Cetacea: Transformation of the Basicranium and Evolution of Hearing in Whales. Univ. Michigan - Pap. Paleontol. 31:1-98.

Luo Z.-X., Marsh K. 1996. Petrosal (Periotic) and Inner Ear of a Pliocene Kogiine Whale (Kogiinae, Odontoceti): Implications on Relationships and Hearing Evolution of Toothed Whales. 16:328348.

Martínez-Cáceres M., de Muizon C. 2011. A new basilosaurid (Cetacea, Pelagiceti) from the Late Eocene to Early Oligocene Otuma Formation of Peru. Comptes Rendus - Palevol. 10:517-526.

Mourlam M.J., Orliac M.J. 2018. Protocetid (Cetacea, Artiodactyla) bullae and petrosals from the middle Eocene locality of Kpogamé, Togo: new insights into the early history of cetacean hearing. J. Syst. Palaeontol. 16:621-644.

Thewissen J.G.M. 1994. Phylogenetic aspects of Cetacean origins: A morphological perspective. J. Mamm. Evol. 2:157-184.

Thewissen J.G.M., Bajpai S. 2009. New skeletal material of Andrewsiphius and Kutchicetus, two Eocene cetaceans from India. J. Paleontol. 83:635-663.

Thewissen J.G.M., Hussain S.T. 2000. Attockicetus praecursor, a new remingtonocetid cetacean from marine eocene sediments of Pakistan. J. Mamm. Evol. 7:133-146.

Uhen M.D. 1998. Middle to late Eocene basilosaurines and dorudontines. In: Thewissen J.G.M., editor. The Emergence of Whales. New York and London: Plenum Press. p. 29-61.

Uhen M.D. 1999. New species of protocetid archaeocete whale, Eocetus wardii (Mammalia: Cetacea) from the middle Eocene of North Carolina. J. Paleontol. 73:512-528.

Uhen M.D., Pyenson N.D., Devries T.J., Urbina M., Renne P.R. 2011. New Middle Eocene Whales from the Pisco Basin of Peru. J. Paleontol. 85:955-969.

Vautrin Q., Lihoreau F., Sambou B., Thiam M., Martin J.E., Tabuce R., Adnet S., Lebrun R., Charruault A.-L., Sarr R., Hautier L. 2020. From limb to fin: an Eocene protocetid forelimb from Senegal sheds new light on the early locomotor evolution of cetaceans. Palaeontology. 63:51-66. 
Figure 1. Postglenoid foramen vs. vascular groove

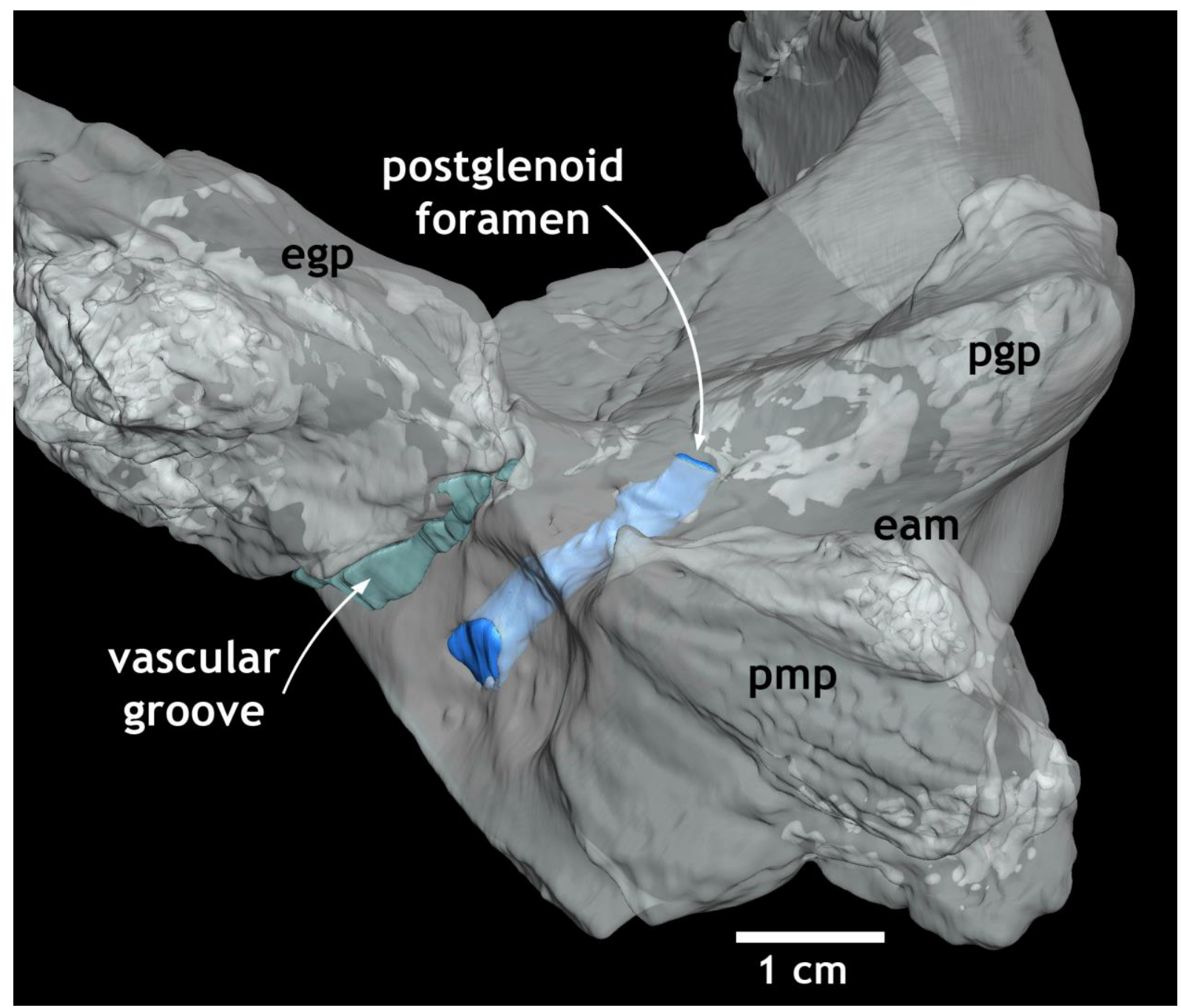

Figure 1. Posteromedial view of the basicranium of KPO1 (in 60\% of transparency), highlighting the pathway of the capsuloparietal emissary vein (in blue) passing through the postglenoid foramen and that of the vascular groove (in turquoise) distant from the postglenoid foramen. Abbreviations: eam, external auditory meatus; egp, entoglenoid process; pgp, postglenoid process; pmp, postmeatal process. Scale bar represents $1 \mathrm{~cm}$.

Figure 1. Vue postéro-médiale du basicrâne de KPO1 (à 60\% de transparence), illustrant le passage de la veine émissaire capsulopariétale (en bleu) passant par le foramen post-glénoïde, ainsi que le passage du sillon vasculaire (en turquoise) distant du foramen post-glénoïde. Abréviations : eam, méat auditif externe ; egp, processus entoglénoïde ; pgp, processus post-glénoïde; pmp, processus post-méatal. La barre d'échelle représente $1 \mathrm{~cm}$. 
Figure 2. Entoglenoid process of morphotype $\gamma$
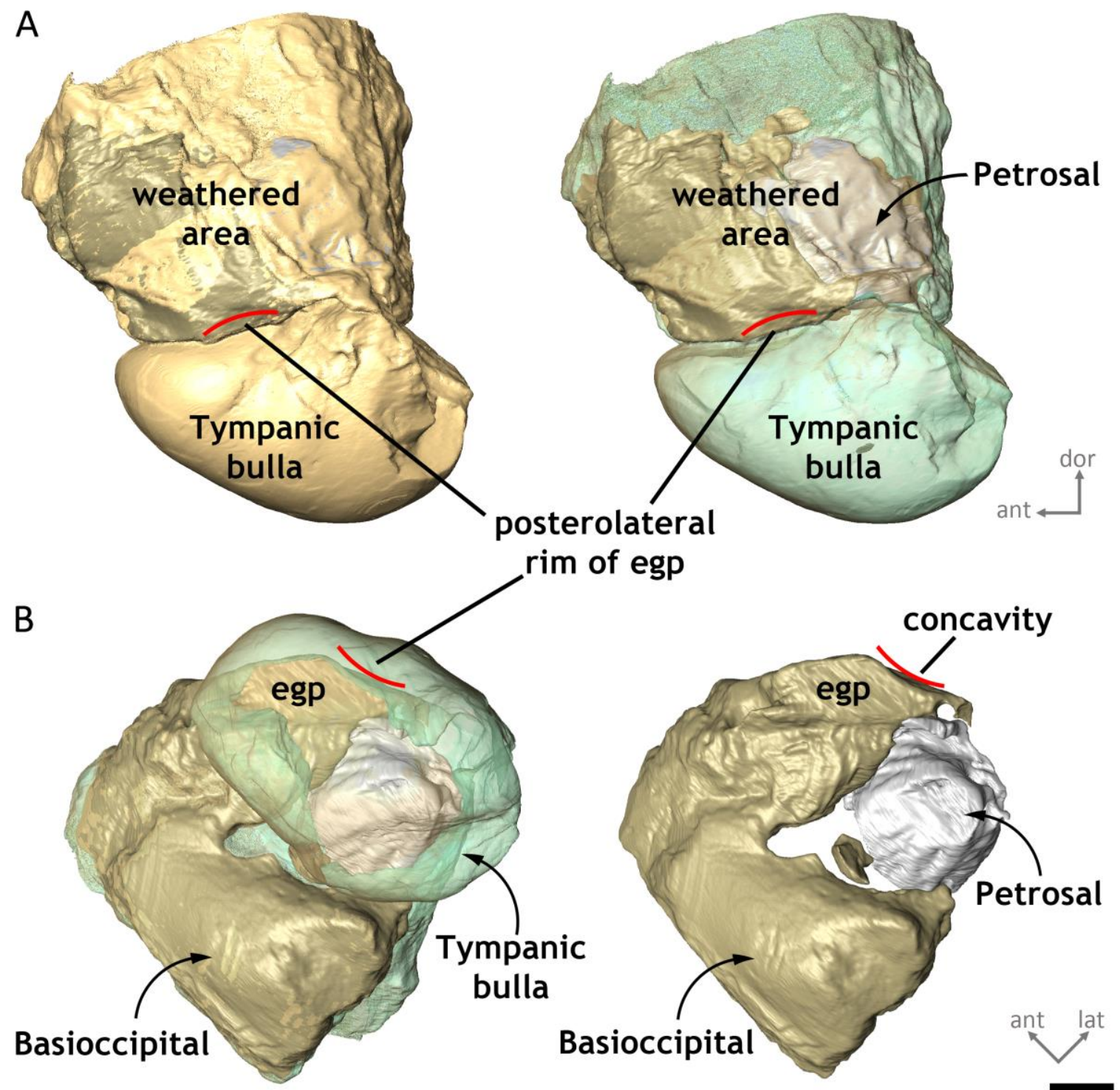

\section{B}

A

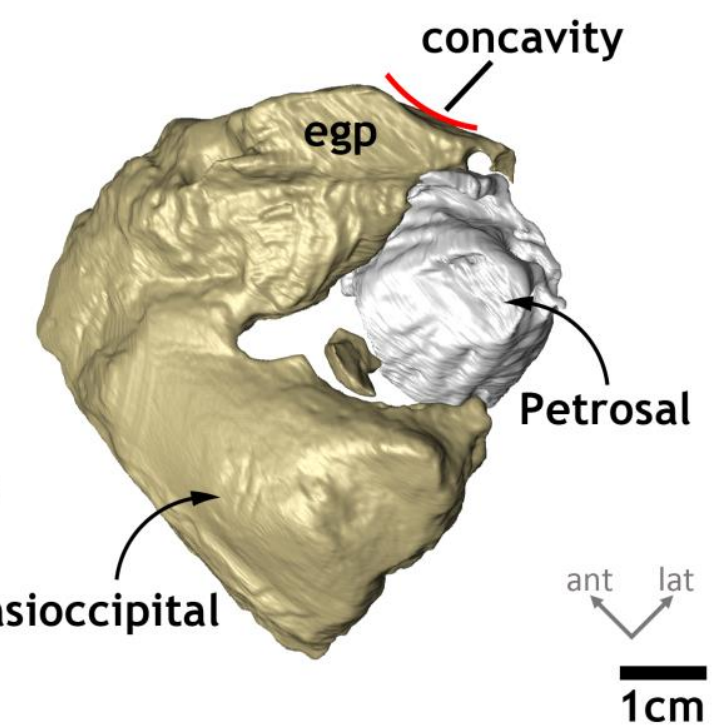

Figure 2. Lateral (A) and ventral (B) views of the auditory region of the morphotype $\gamma$ (UMKPG-M 73) highlighting (A) the weathered area of this specimen suggesting that the posterolateral rim of the entoglenoid process (egp) could be partially damaged, but also (B) the close relationship between the morphology of the anterolateral wall of the tympanic bulla and that of the posterolateral rim of the entoglenoid process suggesting that its morphology is nevertheless fairly well preserved. 3D surface of morphotype $\gamma$ (UM-KPG-M 73) kindly provided by Maëva J. Orliac (ISEM).

Figure 2. Vues latérale (A) et ventrale (B) de la région auditive du morphotype $\gamma$ (UM-KPGM 73) afin d'illustrer la zone altérée de ce spécimen suggérant que le bord postéro-latéral du processus entoglénoïde (egp) pourrait être partiellement endommagé (A), mais aussi la relation étroite entre la morphologie du bord antérolatérale de la bulle tympanique et celle du bord postéro-latéral du processus entoglénoïde suggérant que sa morphologie est malgré tout assez bien préservée (B). Surface 3D du morphotype $\gamma$ (UM-KPG-M 73) aimablement fournie par Maëva J. Orliac (ISEM) 
Figure 3. Strict consensus - Similarity index

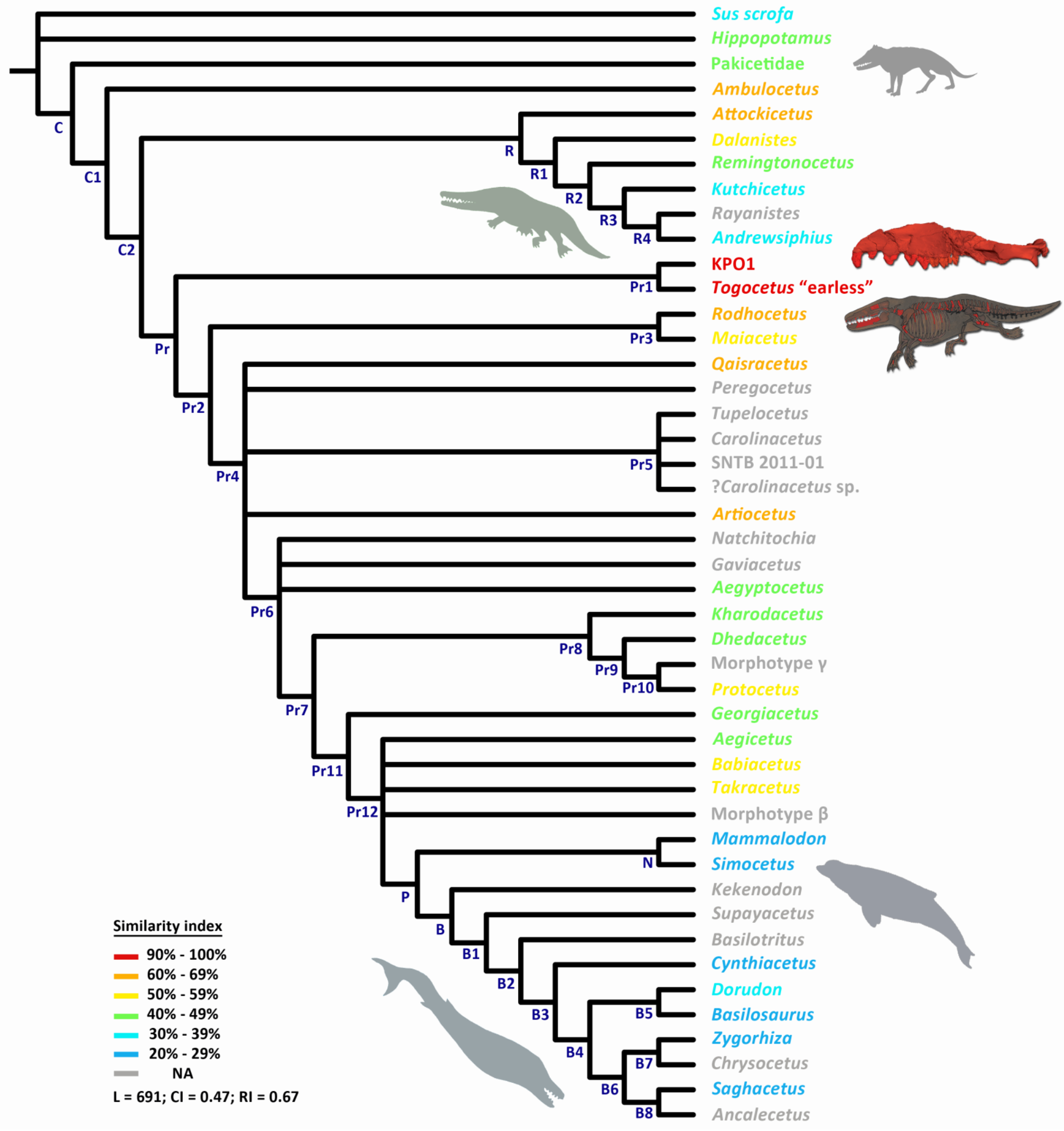


Figure 3. Phylogenetic tree of basal cetaceans based on the main cladistics analysis of this study (see Figure 7 and the Material and method section), highlighting the similarity index between KPO1 and the other taxa of this analysis. In grey, taxa with a shared index lower than $40 \%$. Data about the shared and similarity indexes are available in Supplemental Table 1 . Topology of the strict consensus $(\mathrm{L}=$ 691; $\mathrm{CI}=0.47$; $\mathrm{RI}=0.67)$ of the 2,100 most parsimonious trees $(\mathrm{L}=674 ; \mathrm{CI}=0.49 ; \mathrm{RI}=0.68)$. Illustrations by R. Mourlam.

Figure 3. Arbre phylogénétique de cétacés basaux issu de l'analyse cladistique principale (voir Figure 7 et la section Matériel et méthode) illustrant l'indice de similarité entre KPO1 et les autres taxons de l'analyse. En gris, taxons dont l'indice de partage est inférieur à $40 \%$. Les valeurs des indices de partage et de similarité sont disponibles au Tableau 1 de cette annexe. Topologie du consensus strict $(\mathrm{L}=691 ; \mathrm{CI}=0.47 ; \mathrm{RI}=0.67)$ de 2100 arbres les plus parcimonieux $(\mathrm{L}=674 ; \mathrm{CI}=0.49 ; \mathrm{RI}=0.68)$. Illustrations faites par R. Mourlam. 
Figure 4. Strict consensus - without Togocetus "earless"

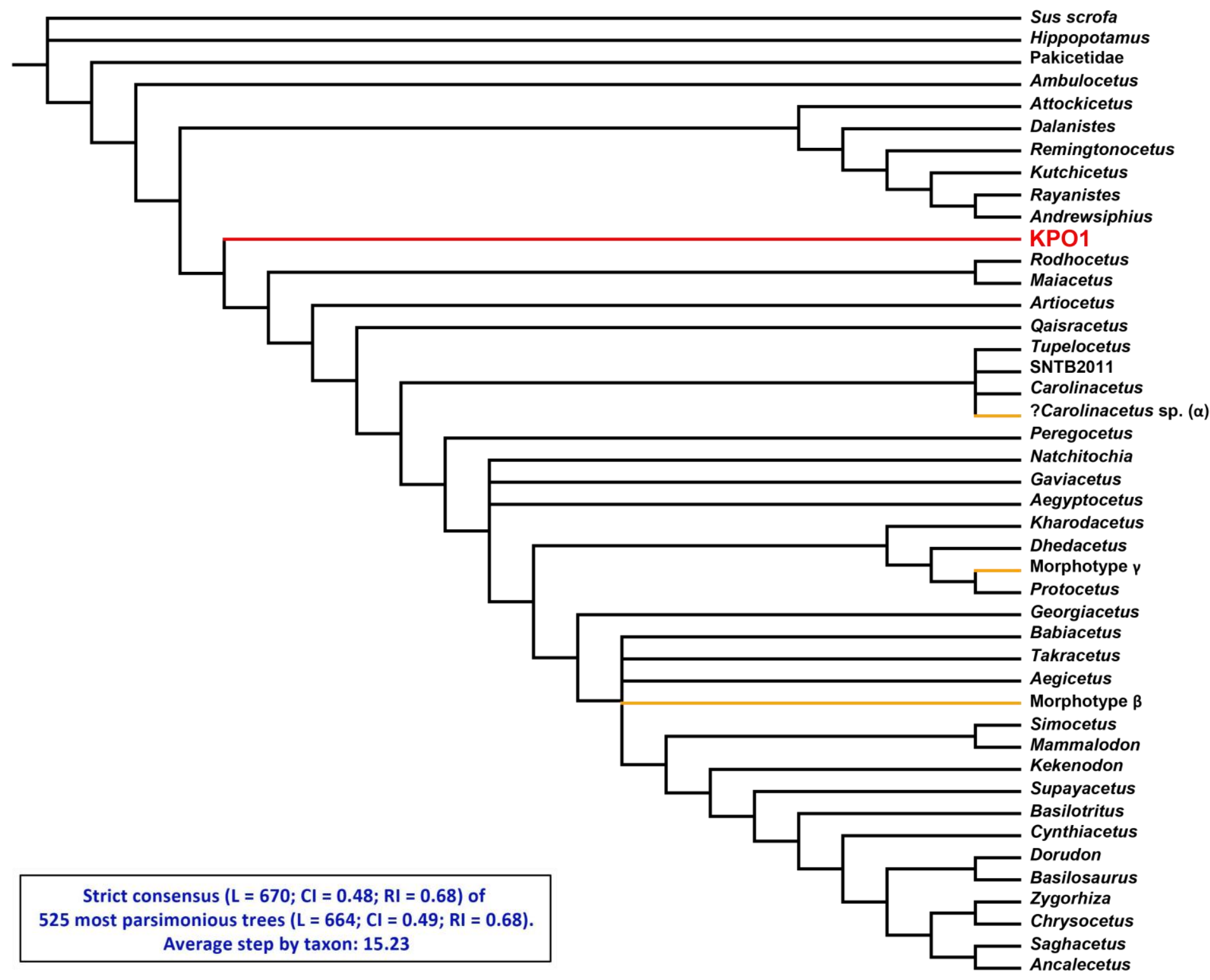

Figure 4. Phylogenetic tree of basal cetaceans based on the cladistic analysis of 44 taxa (i.e. without T. traversei described by Gingerich \& Cappetta 2014) and 167 morphological characters. KPO1 is here indicated in red. The other protocetids from Togo are indicated in orange. Topology of the strict consensus $(\mathrm{L}=670 ; \mathrm{CI}=0.48 ; \mathrm{RI}=0.68)$ of the 525 most parsimonious trees $(\mathrm{L}=664 ; \mathrm{CI}=0.49 ; \mathrm{RI}$ $=0.68)$.

Figure 4. Arbre phylogénétique des cétacés basaux issu de l'analyse cladistique de 44 taxons (i.e. sans T. traversei décrit par Gingerich \& Cappetta 2014) et 167 caractères morphologiques. KPO1 est indiqué ici en rouge. Les autres protocètes du Togo sont indiqués en orange. Topologie du consensus strict $(\mathrm{L}=670 ; \mathrm{CI}=0.48 ; \mathrm{RI}=0.68)$ de 525 arbres les plus parcimonieux $(\mathrm{L}=664 ; \mathrm{CI}=0.49 ; \mathrm{RI}=$ 0.68 ). 
Figure 5. Strict consensus - Togocetus "earless" hypothesis

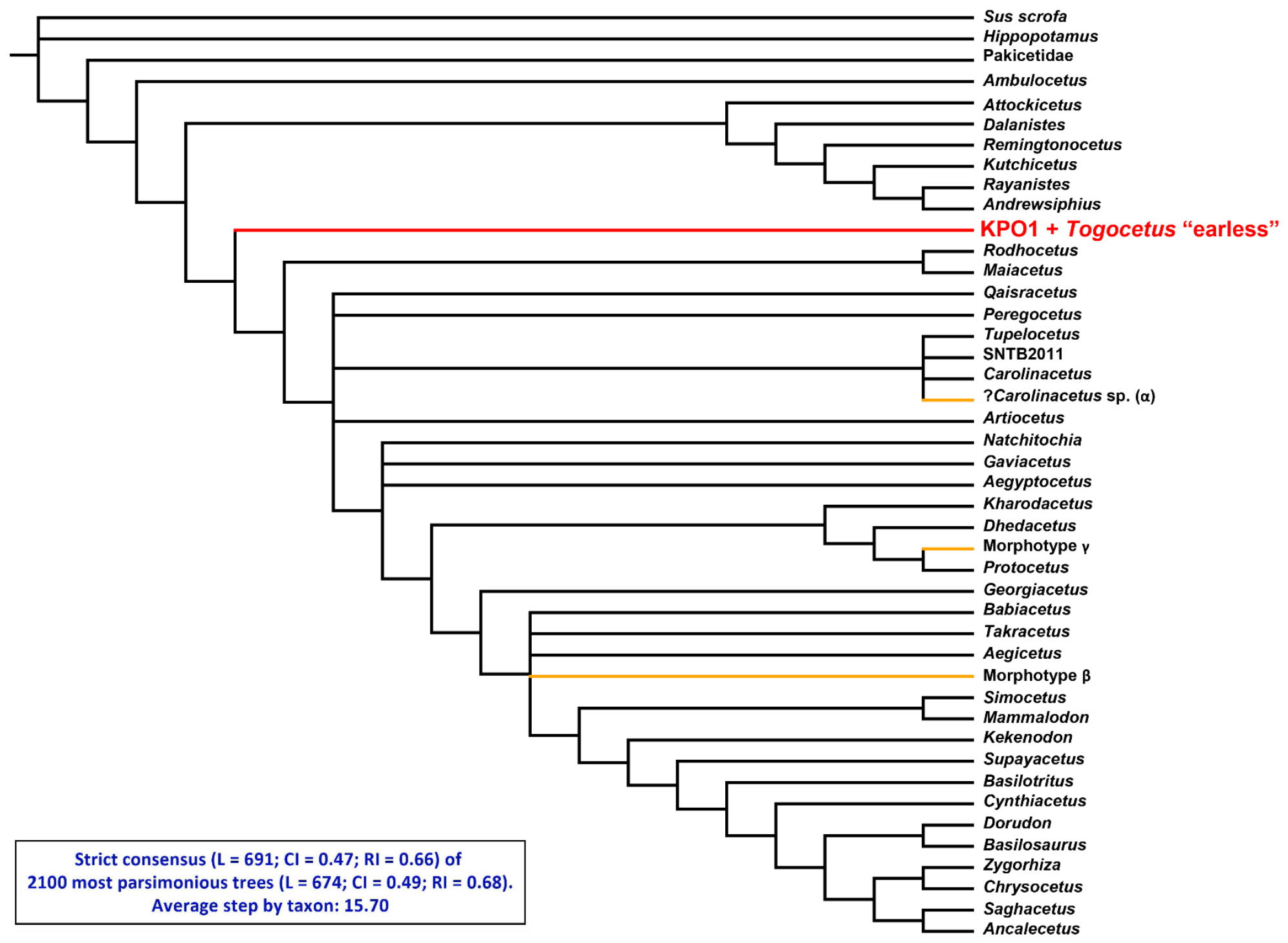

Figure 5. Phylogenetic tree of basal cetaceans based on the cladistics analysis of 44 taxa and 167 morphological characters following the hypothesis that the auditory region of the genus Togocetus is missing; i.e. KPO1 + Togocetus « earless » = one single operational taxonomic unit (OTU). This taxon is here indicated in red. The other protocetids from Togo are indicated in orange. Topology of the strict consensus $(\mathrm{L}=691 ; \mathrm{CI}=0.47 ; \mathrm{RI}=0.66)$ of the 2,100 most parsimonious trees $(\mathrm{L}=674 ; \mathrm{CI}=$ $0.49 ; \mathrm{RI}=0.68$ ).

Figure 5. Arbre phylogénétique des cétacés basaux issu de l'analyse cladistique de 44 taxons et 167 caractères morphologiques suivant l'hypothèse selon laquelle la région auditive du genre Togocetus est inconnue ; i.e. KPO1 + Togocetus «earless »= une seule et même Unité Evolutive (UE). Ce taxon est indiqué ici en rouge. Les autres protocètes du Togo sont indiqués en orange. Topologie du consensus strict $(\mathrm{L}=691 ; \mathrm{CI}=0.47$; $\mathrm{RI}=0.66)$ de 2100 arbres les plus parcimonieux $(\mathrm{L}=674 ; \mathrm{CI}=0.49 ; \mathrm{RI}=0.68)$. 
Figure 6. Strict consensus $-\alpha$ hypothesis

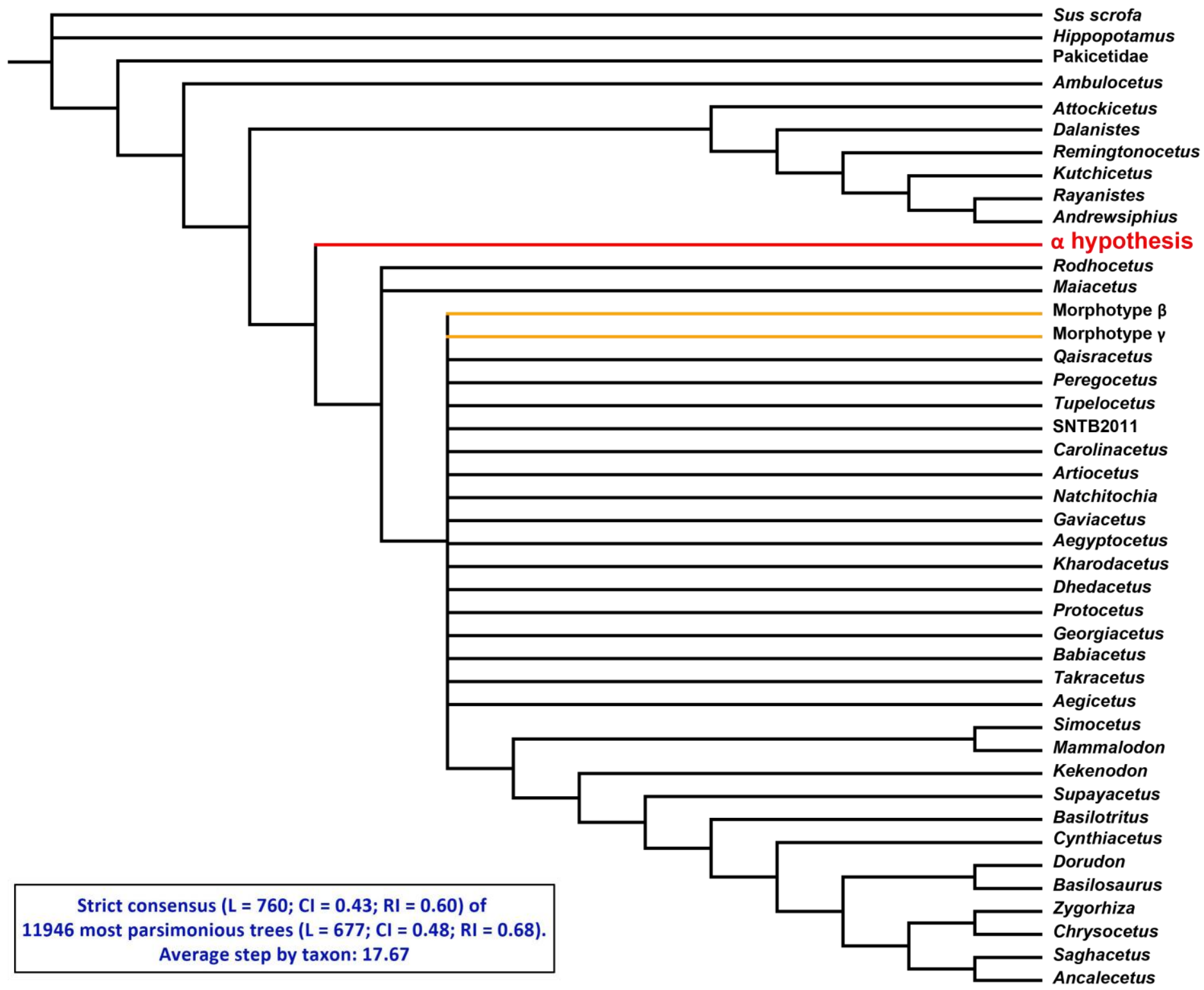

Figure 6. Phylogenetic tree of basal cetaceans based on the cladistics analysis of 43 taxa and 167 morphological characters following the hypothesis that the auditory region of morphotype $\alpha$ belongs to the genus Togocetus; i.e. KPO1 + Togocetus «earless » + morphotype $\alpha=$ one single operational taxonomic unit (OTU). This taxon is here indicated in red. The other protocetids from Togo are indicated in orange. Topology of the strict consensus $(\mathrm{L}=760 ; \mathrm{CI}=0.43 ; \mathrm{RI}=0.60)$ of the 11,946 most parsimonious trees $(\mathrm{L}=677 ; \mathrm{CI}=0.48 ; \mathrm{RI}=0.68)$.

Figure 6. Arbre phylogénétique des cétacés basaux issu de l'analyse cladistique de 43 taxons et 167 caractères morphologiques suivant l'hypothèse selon laquelle la région auditive du morphotype $\alpha$ est associée au genre Togocetus; i.e. KPO1 + Togocetus « earless » + morphotype $\alpha=$ une seule et même Unité Evolutive (UE). Ce taxon est indiqué ici en rouge. Les autres protocètes du Togo sont indiqués en orange. Topologie du consensus strict $(\mathrm{L}=760 ; \mathrm{CI}=0.43 ; \mathrm{RI}=0.60)$ de 11946 arbres les plus parcimonieux $(\mathrm{L}=677 ; \mathrm{CI}=0.48 ; \mathrm{RI}=0.68)$. 
Figure 7. Strict consensus $-\beta$ hypothesis

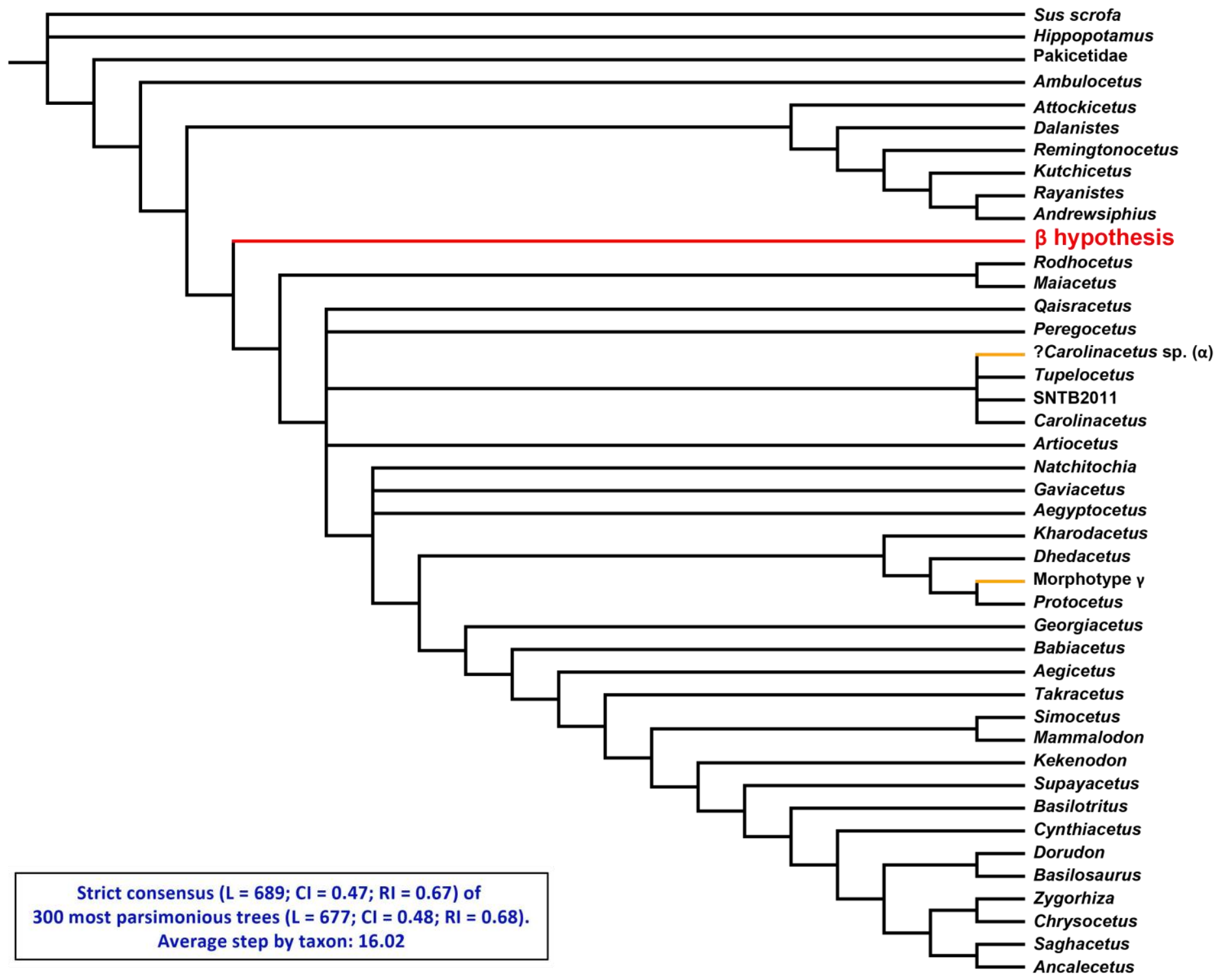

Figure 7. Phylogenetic tree of basal cetaceans based on the cladistics analysis of 43 taxa and 167 morphological characters following the hypothesis that the auditory region of morphotype $\beta$ belongs to the genus Togocetus; i.e. KPO1 + Togocetus «earless » + morphotype $\beta=$ one single operational taxonomic unit (OTU). This taxon is here indicated in red. The other protocetids from Togo are indicated in orange. Topology of the strict consensus $(\mathrm{L}=689 ; \mathrm{CI}=0.47 ; \mathrm{RI}=0.67)$ of the 300 most parsimonious trees $(\mathrm{L}=677 ; \mathrm{CI}=0.48 ; \mathrm{RI}=0.68)$.

Figure 7. Arbre phylogénétique des cétacés basaux issu de l'analyse cladistique de 43 taxons et 167 caractères morphologiques suivant l'hypothèse selon laquelle la région auditive du morphotype $\beta$ est associée au genre Togocetus; i.e. KPO1 + Togocetus « earless » + morphotype $\beta=$ une seule et même Unité Evolutive (UE). Ce taxon est indiqué ici en rouge. Les autres protocètes du Togo sont indiqués en orange. Topologie du consensus strict $(\mathrm{L}=689 ; \mathrm{CI}=0.47 ; \mathrm{RI}=0.67)$ de 300 arbres les plus parcimonieux $(\mathrm{L}=677 ; \mathrm{CI}=0.48 ; \mathrm{RI}=0.68)$. 
Figure 8. Strict consensus $-\gamma$ hypothesis

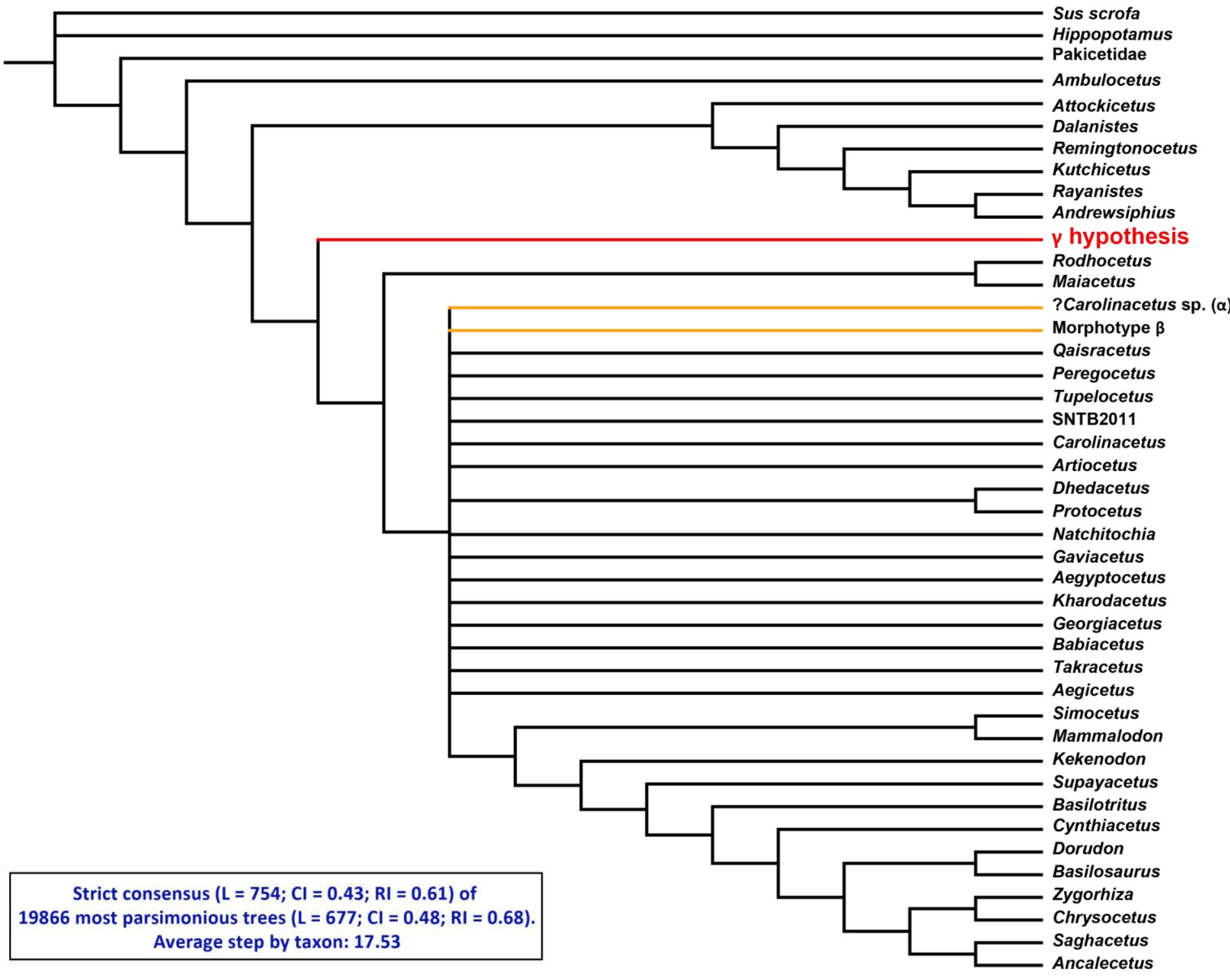

Figure 8. Phylogenetic tree of basal cetaceans based on the cladistics analysis of 43 taxa and 167 morphological characters following the hypothesis that the auditory region of morphotype $\gamma$ belongs to the genus Togocetus; i.e. KPO1 + Togocetus «earless » + morphotype $\gamma=$ one single operational taxonomic unit (OTU). This taxon is here indicated in red. The other protocetids from Togo are indicated in orange. Topology of the strict consensus $(\mathrm{L}=754 ; \mathrm{CI}=0.43 ; \mathrm{RI}=0.61)$ of the 19,866 most parsimonious trees $(\mathrm{L}=677 ; \mathrm{CI}=0.48 ; \mathrm{RI}=0.68)$.

Figure 8. Arbre phylogénétique des cétacés basaux issu de l'analyse cladistique de 43 taxons et 167 caractères morphologiques suivant l'hypothèse selon laquelle la région auditive du morphotype $\gamma$ est associée au genre Togocetus; i.e. KPO1 + Togocetus « earless » + morphotype $\gamma=$ une seule et même Unité Evolutive (UE). Ce taxon est indiqué ici en rouge. Les autres protocètes du Togo sont indiqués en orange. Topologie du consensus strict $(\mathrm{L}=754 ; \mathrm{CI}=0.43 ; \mathrm{RI}=0.61)$ de 19,866 arbres les plus parcimonieux $(\mathrm{L}=677 ; \mathrm{CI}=0.48 ; \mathrm{RI}=0.68)$. 
Table 1. Shared and Similarity indexes

\begin{tabular}{|c|c|c|c|c|c|c|c|c|c|c|c|c|c|c|}
\hline & \multirow{2}{*}{\multicolumn{2}{|c|}{\begin{tabular}{|c|} 
Full Matrix \\
Number of coded characters Total Percentage
\end{tabular}}} & \multicolumn{4}{|c|}{ Comparison with KPO1 } & \multicolumn{4}{|c|}{ Comparison with Togocetus } & \multicolumn{4}{|c|}{ Comparison with KPO1 + Togocetus } \\
\hline & & & Shared with & Shared index & Similarity & Similarity index & Shared with & Shared index & Similarity & Similarity index & Shared with & Shared index & Similarity & Similarity index \\
\hline KPO1 & 40 & 23.95 & 40 & 100.00 & 40 & 100 & 16 & 41.03 & 15 & \begin{tabular}{|l|l}
93.75 \\
\end{tabular} & 40 & 63 & 40 & 100 \\
\hline Togocetus & 39 & 23.35 & 16 & 40.00 & 15 & 93.75 & 39 & 100.00 & 39 & 100 & 39 & 62 & 39 & 100 \\
\hline KPO1+Togocetus & 63 & 37.72 & 40 & 100.00 & 40 & 100 & 39 & 100.00 & 39 & 100 & 63 & 100 & 63 & 100 \\
\hline Hippopotamus & 147 & 88.02 & 37 & 92.50 & 18 & 48.65 & 32 & 82.05 & 14 & 43.75 & 55 & 87 & 23 & 41.82 \\
\hline Pakicetidae & 132 & 79.04 & 35 & 87.50 & 17 & 48.57 & 31 & 79.49 & 13 & 41.94 & 50 & 79 & 21 & 42.00 \\
\hline Ambulocetus & 75 & 44.91 & 19 & 47.50 & 12 & 63.16 & 23 & 58.97 & 12 & 52.17 & 34 & 54 & 19 & 55.88 \\
\hline Andrewsiphius & 39 & 23.35 & 23 & 57.50 & 7 & 30.43 & 22 & 56.41 & 5 & 22.73 & 36 & 57 & 11 & 30.56 \\
\hline Attockicetus & 21 & 12.57 & 17 & 42.50 & 11 & 64.71 & 11 & 28.21 & 7 & 63.64 & 17 & 27 & 11 & 64.71 \\
\hline Dalanistes & 79 & 47.31 & 28 & 70.00 & 14 & 50.00 & 15 & 38.46 & 5 & 33.33 & 36 & 57 & 17 & 47.22 \\
\hline Rayanistes & 14 & 8.38 & 0 & 0.00 & NA & NA & 5 & 12.82 & 3 & 60.00 & 5 & 8 & 3 & 60.00 \\
\hline Remingtonocetus & 112 & 67.07 & 36 & 90.00 & 17 & 47.22 & 28 & 71.79 & 13 & 46.43 & 52 & 83 & 24 & 46.15 \\
\hline Aegicetus & 101 & 60.48 & 23 & 57.50 & 11 & 47.83 & 37 & 94.87 & 19 & 51.35 & 45 & 71 & 25 & 55.56 \\
\hline Aegyptocetus & 68 & 40.72 & 36 & 90.00 & 17 & 47.22 & 30 & 76.92 & 15 & 50.00 & 51 & 81 & 26 & 50.98 \\
\hline Artiocetus & 90 & 53.89 & 32 & 80.00 & 20 & 62.50 & 17 & 43.59 & 11 & 64.71 & 37 & 59 & 23 & 62.16 \\
\hline Babiacetus & 64 & 38.32 & 28 & 70.00 & 14 & 50.00 & 21 & 53.85 & 8 & 38.10 & 35 & 56 & 17 & 48.57 \\
\hline Carolinacetus & 87 & 52.10 & 6 & 15.00 & 3 & 50.00 & 18 & 46.15 & 11 & 61.11 & 22 & 35 & 12 & 54.55 \\
\hline Dhedacetus & 37 & 22.16 & 21 & 52.50 & 9 & 42.86 & 16 & 41.03 & 9 & 56.25 & 23 & 37 & 11 & 47.83 \\
\hline Gaviacetus & 58 & 34.73 & 14 & 35.00 & 9 & 64.29 & 7 & 17.95 & 5 & 71.43 & 16 & 25 & 10 & 62.50 \\
\hline Georgiacetus & 134 & 80.24 & 36 & 90.00 & 16 & 44.44 & 30 & 76.92 & 16 & 53.33 & 54 & 86 & 27 & 50.00 \\
\hline Kharodacetus & 42 & 25.15 & 29 & 72.50 & 13 & 44.83 & 19 & 48.72 & 8 & 42.11 & 35 & 56 & 17 & 48.57 \\
\hline Maiacetus & 91 & 54.49 & 26 & 65.00 & 13 & 50.00 & 24 & 61.54 & 9 & 37.50 & 36 & 57 & 18 & 50.00 \\
\hline Peregocetus & 44 & 26.35 & 2 & 5.00 & 2 & 100 & 20 & 51.28 & 14 & 70.00 & 20 & 32 & 14 & 70.00 \\
\hline Protocetus & 110 & 65.87 & 36 & 90.00 & 18 & 50.00 & 22 & 56.41 & 15 & 68.18 & 42 & 67 & 23 & 54.76 \\
\hline Qaisracetus & 91 & 54.49 & 29 & 72.50 & 18 & 62.07 & 18 & 46.15 & 13 & 72.22 & 36 & 57 & 24 & 66.67 \\
\hline Rodhocetus & 109 & 65.27 & 26 & 65.00 & 18 & 69.23 & 27 & 69.23 & 19 & 70.37 & 44 & 70 & 31 & 70.45 \\
\hline SNTB 2011-01 & 25 & 14.97 & 0 & 0.00 & NA & NA & 7 & 17.95 & 3 & 42.86 & 7 & 11 & 3 & 42.86 \\
\hline Takracetus & 23 & 13.77 & 18 & 45.00 & 10 & 55.56 & 1 & 2.56 & 1 & 100 & 18 & 29 & 10 & 55.56 \\
\hline Tupelocetus & 16 & 9.58 & 4 & 10.00 & 3 & 75.00 & 2 & 5.13 & 2 & 100 & 4 & 6 & 3 & 75.00 \\
\hline Ancalecetus & 23 & 13.77 & 14 & 35.00 & 6 & 42.86 & 22 & 56.41 & 12 & 54.55 & 27 & 43 & 14 & 51.85 \\
\hline Basilosaurus & 146 & 87.43 & 40 & 100.00 & 10 & 25.00 & 36 & 92.31 & 13 & 36.11 & 60 & 95 & 17 & 28.33 \\
\hline Basilotritus & 45 & 26.95 & 13 & 32.50 & 3 & 23.08 & 18 & 46.15 & 6 & 33.33 & 20 & 32 & 7 & 35.00 \\
\hline Chrysocetus & 67 & 40.12 & 11 & 27.50 & 2 & 18.18 & 20 & 51.28 & 8 & 40.00 & 22 & 35 & 8 & 36.36 \\
\hline Cynthiacetus & 146 & 87.43 & 40 & 100.00 & 11 & 27.50 & 38 & 97.44 & 17 & 44.74 & 62 & 98 & 23 & 37.10 \\
\hline Dorudon & 148 & 88.62 & 36 & 90.00 & 12 & 33.33 & 32 & 82.05 & 17 & 53.13 & 56 & 89 & 25 & 44.64 \\
\hline Saghacetus & 97 & 58.08 & 38 & 95.00 & 11 & 28.95 & 23 & 58.97 & 8 & 34.78 & 46 & 73 & 16 & 34.78 \\
\hline Supayacetus & 29 & 17.37 & 1 & 2.50 & 0 & 0.00 & 4 & 10.26 & 2 & 50.00 & 4 & 6 & 2 & 50.00 \\
\hline Zygorhiza & 131 & 78.44 & 40 & 100.00 & 9 & 22.50 & 31 & 79.49 & 8 & 25.81 & 55 & 87 & 16 & 29.09 \\
\hline Kekenodon & 30 & 17.96 & 5 & 12.50 & 2 & 40.00 & 4 & 10.26 & 2 & 50.00 & 5 & 8 & 2 & 40.00 \\
\hline Mammalodon & 74 & 44.31 & 28 & 70.00 & 8 & 28.57 & 15 & 38.46 & 4 & 26.67 & 33 & 52 & 9 & 27.27 \\
\hline Simocetus & 57 & 34.13 & 28 & 70.00 & 6 & 21.43 & 12 & 30.77 & 1 & 8.33 & 31 & 49 & 7 & 22.58 \\
\hline Similarity index & $90-100 \%$ & & & & & & & Average by gro & & & & & & \\
\hline Similarity index & $70-79 \%$ & & Protocetids & 70.83 & & 52.21 & & 58.97 & & 56.56 & & 65.87 & & 55.77 \\
\hline Similarity index & $30-39 \%$ & & Outgroup & 95.00 & & 42.27 & & 83.33 & & 38.54 & & 88.89 & & 36.70 \\
\hline Similarity index & $20-29 \%$ & & & & & & & & & & & & & \\
\hline Similarity index & $<20 \%$ & & & & & & & & & & & & & \\
\hline Shared index & $<40 \%$ & & & & & & & & & & & & & \\
\hline
\end{tabular}


Table 1. Shared and similarity indexes for KPO1, Togocetus and the association of these two as one single operational taxonomic unit. In addition, the first column indicates the number of coded characters for each taxa along with the percentage of it. For more details in the calculation, see Material and method section.

Tableau 1. Indices de partage et de similarité pour KPO1, Togocetus et l'association de ces deux entités en une seule unité évolutive. De plus, la première colonne du tableau indique le nombre de caractères codés pour chaque taxon ainsi que son pourcentage. Pour plus de détails sur les calculs, voir la section Matériel et méthode. 